\title{
VIABILIDADE ECONÔMICA DE DIFERENTES TIPOS DE EMBALAGENS PARA LARANJA DE MESA: UM ESTUDO DE MULTICASOS NO ESTADO DE SÃO PAULO
}

\author{
LILIAN MALUF DE LIMA
}

\begin{abstract}
Dissertação apresentada à Escola Superior de Agricultura "Luiz de Queiroz", Universidade de São Paulo, para obtenção do título de Mestre em Ciências, Área de Concentração: Economia Aplicada.
\end{abstract}

P I R A C I C A B A

Estado de São Paulo - Brasil

Novembro - 2003 


\title{
VIABILIDADE ECONÔMICA DE DIFERENTES TIPOS DE EMBALAGENS PARA LARANJA DE MESA: UM ESTUDO DE MULTICASOS NO ESTADO DE SÃO PAULO
}

\author{
LILIAN MALUF DE LIMA \\ Engenheiro Agrônomo
}

Orientador: Prof. Dr. JOSÉ VICENTE CAIXETA FILHO

\footnotetext{
Dissertação apresentada à Escola Superior de Agricultura "Luiz de Queiroz", Universidade de São Paulo, para obtenção do título de Mestre em Ciências, Área de Concentração: Economia Aplicada.
}

P I R A C I C A B A

Estado de São Paulo - Brasil

Novembro - 2003 
Dados Internacionais de Catalogação na Publicação (CIP) DIVISÃO DE BIBLIOTECA E DOCUMENTAÇÃO - ESALQ/ USP

\author{
Lima, Lilian Maluf de \\ Viabilidade econômica de diferentes tipos de embalagens para laranja de mesa : um estudo de \\ multicasos no Estado de São Paulo / Lilian Maluf de Lima. - - Piracicaba, 2003. \\ 130 p. : il. \\ Dissertação (mestrado) - - Escola Superior de Agricultura Luiz de Queiroz, 2003. \\ Bibliografia. \\ 1. Beneficiamento 2. Comércio agrícola 3. Custo econômico 4. Embalagem
6. Laranja 7. Transporte 8. Viabilidade econômica 9. Vigilância
sanitária I. Título \\ 5. Exportaçã \\ CDD 338.17431
}

"Permitida a cópia total ou parcial deste documento, desde que citada a fonte - $\mathrm{O}$ autor" 
"Se planejas para um ano, planta arroz; se planejas para dez anos, planta árvores; se planejas para cem anos, educa o povo; se planejas para mil anos, conserva a natureza de seu País” (provérbio chinês) 


\section{OFEREÇO}

Aos meus pais, pela estrutura e apoio

Ao Cido, Zouha, Leonardo e Joaquim, 


\section{AGRADECIMENTOS}

A Deus, pela vida, saúde e paciência...

Um especial agradecimento ao Prof. Dr. José Vicente Caixeta Filho pelas orientações dignas de pai e de mestre, sempre efetuadas com muito apoio, paciência e atenção.

À Prof ${ }^{\mathrm{a}} \operatorname{Dr}^{\mathrm{a}}$ Márcia Azanha Ferraz Dias de Moraes, pelas preciosas sugestões, e também, pelas excelentes aulas ministradas durante o curso de Organização Industrial que muito contribuíram para a definição do tema desta pesquisa.

Ao Prof. Dr. Marcos Fava Neves, pelas valiosas contribuições, principalmente as relacionadas à metodologia no contexto de multicasos, que permitiram melhor estruturação deste trabalho.

Ao Prof. Dr. Evaristo Marzabal Neves, por importantes considerações realizadas em outras versões dessa pesquisa.

Ao Prof. Dr. Francisco de Assis Alves Mourão Filho, pela participação e relevantes sugestões atribuídas ao trabalho.

Ao pesquisador do IPT/USP, Ernesto Freire Pichler, que, em todos os momentos solicitados, se mostrou prestativo e paciente, tanto no desenvolvimento do tema da dissertação, como no fornecimento de dados de pesquisas realizadas.

Ao Dr. Umberto Antônio Sesso Filho, que, em meu seminário indicou questões que muito contribuíram para o aperfeiçoamento da pesquisa.

À CNPq e à FEALQ pelo apoio financeiro concedido durante a pesquisa. 
Aos demais professores do Departamento de Economia, Administração e Sociologia da ESALQ pelo aprendizado e desenvolvimento acadêmico.

A todos os funcionários não docentes, especialmente à Maielli, pela incansável dedicação ao trabalho e aos alunos de pós-graduação.

Às Fazendas Reunidas Raio de Sol, pelo fornecimento e pela permissão de uso da planilha como instrumental metodológico deste trabalho. Em especial, agradeço ao gerente geral da Raio de Sol, Mauro Pereira Gomes, por se apresentar sempre muito gentil e solícito perante minhas dúvidas e incompreensões.

Aos produtores entrevistados que compuseram os resultados desta pesquisa e, gentilmente, permitiram a divulgação de seus dados, fundamentais para a conclusão desse trabalho.

À CEAGESP e à ABRE, que sempre se mostraram muito prestativas quanto ao fornecimento de dados.

À Equipe Hortifruti Brasil, que gentilmente contribuiu com o fornecimento de contatos de produtores de citros.

Aos amigos que, com muita competência, compõem a equipe SIFRECA: Bruno, Claudi, Mariana, Marina e Priscila. À Equipe, muito obrigada pelo carinho, pela compreensão e pela amizade.

Ao amigo Gustavo Henrique Fidelis Taglialegna, pela verdadeira amizade e apoio concedidos principalmente no início do curso de mestrado.

Aos amigos do mestrado, pelo companheirismo ao longo do curso.

Ao querido Joaquim, com quem compartilhei angústias, idéias, ansiedades, alegrias e tristezas. Encontrei compreensão, carinho e amor, principalmente nos momentos finais de minha pesquisa. 
Enfim, aos meus pais, por participarem de mais uma conquista em minha vida. 


\section{SUMÁRIO}

Página

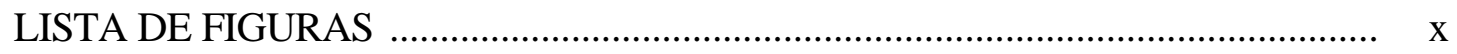

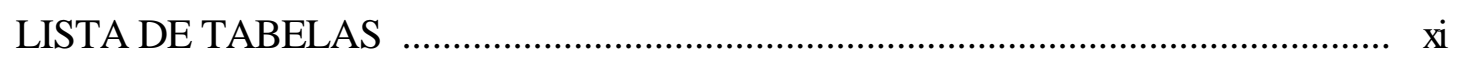

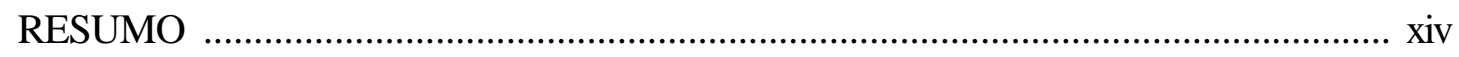

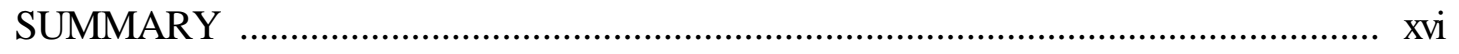

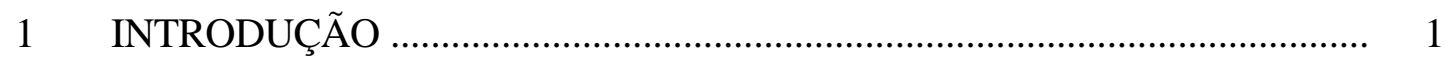

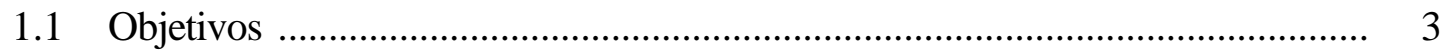

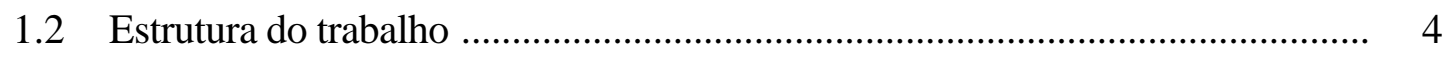

2 REVISÃO DE LITERATURA ………............................................... 5

2.1 Embalagem: histórico e algumas definições ................................................... 5

2.2 A importância da embalagem como instrumento de marketing ........................ 11

2.3 Embalagens para laranja de mesa no mercado interno brasileiro ...................... 12

2.3.1 Embalagens de madeira ............................................................................. 15

2.3.2 Embalagens de papelão ondulado .................................................................. 17

2.3.3 Embalagens de plástico ............................................................................. 22

2.4 Padronização de embalagens ................................................................... 26

2.4.1 Legislação brasileira sobre embalagens para hortifrutis .................................. 32

2.5 Considerações finais .................................................................................. 34

3 MATERIAL E MÉTODOS ………………........................................ 35

3.1 Descrição do ambiente ............................................................................. 35

3.2 Métodos de avaliação econômica de embalagens documentados na literatura .. 38 
3.3 Método proposto e instrumental metodológico ............................................... 68

3.4 Especificação dos dados ......................................................................... 70

3.5 Considerações finais ................................................................................... 74

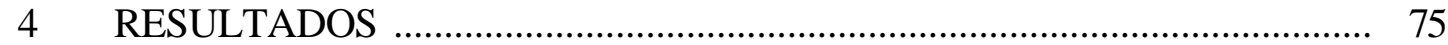

4.1 Caracterização do tipo de embalagem para laranja de mesa e do seu processo de utilização sob a ótica do produtor entrevistado " 1 ” ....................... 75

4.2 Caracterização do tipo de embalagem para laranja de mesa e do seu processo de utilização sob a ótica do produtor entrevistado " 2 " ...................... 79

4.3 Caracterização do tipo de embalagem para laranja de mesa e do seu processo de utilização sob a ótica do produtor entrevistado 3 ........................ 82

4.4 Viabilidade econômica dos diferentes tipos de embalagem ............................. 85

4.4.1 Resultados específicos para o entrevistado "1" .............................................. 85

4.4.2 Resultados específicos para o entrevistado " 2 " ............................................... 94

4.4.3 Resultados específicos do entrevistado "3” ................................................... 102

4.5 Considerações finais sobre os entrevistados ................................................ 108

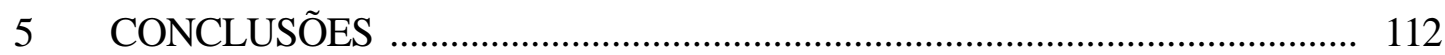

REFERÊNCIAS BIBLIOGRÁFICAS ........................................................... 120

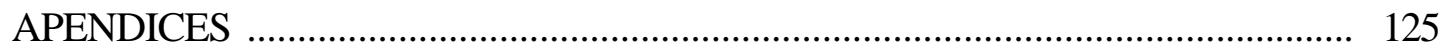




\section{LISTA DE FIGURAS}

Página

1 Participação dos tipos de embalagens na CEAGESP, 2002 ............................... 14

2 Embalagem de madeira tipo "M" ............................................................... 15

3 Caixa de papelão ondulado para laranja ............................................................ 17

4 Papelão ondulado composto por 2 miolos (ondas) ............................................. 18

5 Etiqueta padronizada para caixas de papelão (laranja) ........................................ 20

6 Marcas e símbolos da caixa de papelão ondulado ................................................ 21

7 Embalagem de plástico excessivamente aberta no fundo ................................... 24

8 Embalagem de plástico ............................................................................. 24

9 Cores de embalagens de exportação e preferências de cada país .......................... 30

10 Fluxo das caixas de madeira tipo "M" no mercado interno de São Paulo ........... 37 


\section{LISTA DE TABELAS}

Página

1 Utilização dos diferentes tipos de matérias-primas para embalagens em 1996-

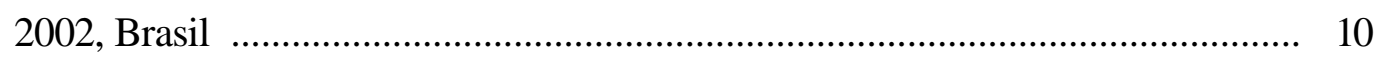

2 Principais diferenças entre caixas de madeira, de plástico e de papelão, 2003 .... 25

3 Custos de sistemas de manuseio de banana na República Dominicana .............. 40

4 Custos das embalagens para a comercialização do tomate produzido em Indaiatuba - SP e vendido na CEAGESP, conforme tipo de embalagem, 1976

5 Perdas $x$ custos, de acordo com o tipo de embalagem para tomate .................... 43

6 Valor dos custos e das perdas por tipo de embalagem de tomate, 1976 .............. 44

7 Custo da embalagem de madeira retornável, 2001 ............................................. 48

8 Custo total com embalagens referentes a 10 viagens, 2001 .............................. 49

9 Planilha de custos ilustrativos de venda de laranja de mesa, em diferentes níveis de refugo e tipos de embalagens, 2003 ................................................... 52

10 Especificações de cada cenário considerado, 2003 ............................................. 73

11 Cálculo de custo referente à utilização da embalagem de madeira tipo "M", comprada e retornável, entrevistado "1", 2003 .................................................. 87

12 Nível porcentual de lucro com depreciação para os diferentes tipos de embalagens e respectivos sistemas, em diferentes níveis de refugo, referentes ao entrevistado "1", cenário 1, 2003

13 Nível porcentual de lucro com depreciação para os diferentes tipos de embalagens e respectivos sistemas, em diferentes níveis de refugo, referentes ao entrevistado "1", cenário 2, 2003 
14 Nível porcentual de lucro com depreciação para os diferentes tipos de embalagens e respectivos sistemas, em diferentes níveis de refugo, referentes ao entrevistado "1", cenário 3, 2003

15 Cálculo de custo referente à utilização da embalagem de papelão $(18 \mathrm{~kg})$, entrevistado " 2 ", 2003

16 Nível porcentual de lucro com depreciação para os diferentes tipos de embalagens e respectivos sistemas, em diferentes níveis de refugo, referentes ao entrevistado "2", cenário 1, considerando-se perdas por utilização de embalagens de papelão e madeira, 2003

17 Nível porcentual de lucro com depreciação para os diferentes tipos de embalagens e respectivos sistemas, em diferentes níveis de refugo, referentes ao entrevistado "2", cenário 2, considerando-se perdas por utilização de embalagens de papelão e madeira, 2003

18 Nível porcentual de lucro com depreciação para os diferentes tipos de embalagens e respectivos sistemas, em diferentes níveis de refugo, referentes ao entrevistado "2", cenário 3, considerando-se perdas por utilização de embalagens de papelão e madeira, 2003

19 Cálculo de custo referente à utilização da embalagem de plástico $(20 \mathrm{~kg})$, sob o sistema de aluguel, entrevistado " 3 "

20 Nível porcentual de lucro com depreciação para os diferentes tipos de embalagens e respectivos sistemas, em diferentes níveis de refugo, referentes ao entrevistado “3”, cenário 1, 2003

21 Nível porcentual de lucro com depreciação para os diferentes tipos de embalagens e respectivos sistemas, em diferentes níveis de refugo, referentes ao entrevistado "3”, cenário 2, 2003

22 Nível porcentual de lucro com depreciação para os diferentes tipos de embalagens e respectivos sistemas, em diferentes níveis de refugo, referentes ao entrevistado "3”, cenário 3, 2003

23 Embalagens utilizadas ou recomendadas para cada produtor, 2003 
24 Preço do $\mathrm{kg}$ da fruta, nos cenários considerados, utilizando-se determinadas embalagens, para obtenção de um valor a partir do qual se obtém valores de lucro com depreciação em todos os níveis de refugo, para cada entrevistado, 2003 


\title{
VIABILIDADE ECONÔMICA DE DIFERENTES TIPOS DE EMBALAGENS PARA LARANJA DE MESA: UM ESTUDO DE MULTICASOS NO ESTADO DE SÃO PAULO
}

\author{
Autora: LILIAN MALUF DE LIMA
}

Orientador: Prof. Dr. JOSÉ VICENTE CAIXETA FILHO

\section{RESUMO}

O presente trabalho teve como objetivo principal identificar o tipo de embalagem mais viável economicamente para laranja de mesa, produzida e comercializada no Estado de São Paulo. Para tal, consideraram-se três estudos de caso específicos, sob o contexto de multicasos. Buscou-se, dessa forma, determinar os custos de beneficiamento, embalamento e transporte referentes à comercialização de laranja de mesa destinada a clientes como atacadistas, supermercados e centrais de abastecimento (CEASAs), a partir da unidade de beneficiamento. Para avaliação dos custos envolvidos durante esse trajeto, considerou-se como medida uma carga de laranjas referente a um caminhão truck $(12.040 \mathrm{~kg})$, em diferentes níveis de refugo $(15 \%, 20 \%, 25 \%, 30 \% \mathrm{e}$ $35 \%$ ), vinda da unidade produtora até o Packing-House. Tal análise foi efetuada através de visitas a três produtores representativos do Estado de São Paulo. As informações foram obtidas por meio de entrevistas e aferição dos dados específicos dos 
entrevistados na planilha Fazendas Reunidas Raio de Sol, op. cit., p.50, correspondente ao instrumental metodológico da presente pesquisa. Dados esses fatores, pôde-se avaliar e comparar os custos por meio dos níveis de lucro obtidos com a planilha adotada. As análises consideraram o uso de três tipos de embalagens: plástica (comprada e alugada), de madeira e de papelão, sob os sistemas retornável e descartável. Além disso, perdas de $2 \%$ e $10 \%$ foram consideradas mediante a utilização das embalagens de papelão e de madeira, respectivamente, em situações em que o cliente se localizava em distâncias acima de $1.000 \mathrm{~km}$ a partir da unidade de beneficiamento. Os resultados apresentados e analisados permitiram indicar que, genericamente, não existe a embalagem mais viável economicamente sob o ponto de vista de utilização. $\mathrm{O}$ que realmente se observou é que existe a embalagem mais viável economicamente para cada produtor, dadas suas características específicas, como: formas de negociação de fretes com o cliente, pagamento de taxas referentes ao transporte, níveis de perdas relativos ao uso de determinadas embalagens em longas distâncias, variações de preços da fruta vendida ao cliente e à indústria, valores referentes ao beneficiamento, intermediação e taxas de desconto financeiro (conforme o tipo de supermercado). Com a utilização da planilha Fazendas Reunidas Raio de Sol, op. cit., p.50, o produtor poderá utilizar um instrumental para tomada de decisões referentes não somente ao uso da embalagem mais viável, mas também como um suporte na definição do melhor preço de venda de suas frutas ( $\mathrm{R} \$ / \mathrm{kg})$, a partir do qual possam ser observados lucros em todos os níveis de refugo. 


\title{
ECONOMIC FEASIBILITY OF DIFFERENT PACKAGING TYPES FOR FRESH ORANGES CONSUMPTION: A STUDY OF MULTI CASES IN THE SÃO PAULO STATE
}

\author{
Author: LILIAN MALUF DE LIMA
}

Advisor: Prof. Dr. JOSÉ VICENTE CAIXETA FILHO

\section{SUMMARY}

This current study aims to identify the most feasible type of packages for fresh oranges, produced and commercialized in the São Paulo state. In order to do so, three studies of specific cases were considered, under the context of multi cases. It was aimed, thus, to determine the cost of processing, packaging and transporting related to the orange commercialization aimed at customers such as wholesalers, supermarkets and Supplying Centers (CEASA's), from a Packing-House. To evaluate the costs involved in this process, it was considered as a form of measurement the amount of orange carried by a truck $(12,040 \mathrm{~kg})$, in different levels of refusal $(15 \%, 20 \%, 25 \%, 30 \%$ and $35 \%)$, coming from the producing unit up to the Packing-House. Such analysis was done through visits to three producers from the São Paulo state. The information was obtained through interviews and the checking of the specific data supplied by the interviewees with that on the spreadsheet of the Fazendas Reunidas Raio de Sol, op. cit., p.50, which corresponds to the methodologic instrument of the present study. Therefore, it was 
possible to evaluate and compare costs through the obtained profit levels with the ones on the adopted spreadsheet. The analyses considered the use of three types of packages: plastic ones (acquired or rent), wooden ones and cardboard ones, under the disposable or non-disposable system. Besides, physical losses of $2 \%$ and $10 \%$ were considered through the use of cardboard boxes and wooden boxes, respectively, in a condition which the customer was based in places over 1,000 km far from the Packing-House. The results presented and analyzed in this study allowed to indicate that, in general terms, there is no package more feasible economically speaking, considering its use. What was really observed was that there is a package that is more feasible for each producer considering his specific characteristics, such as: forms of freight negotiations with the customer, the payment of taxes related to transportation, loss levels related to the use of determined packages in long distances, variations of the fruit prices sold to the customer and to the industry, values related to the processing, arbitrage and taxes of financial discounts (according to the type of supermarket). With the use of the spreadsheet of the Fazendas Reunidas Raio de Sol, op. cit., p.50, the producer will be able to use a tool to help make decisions related not only to the most feasible package to be used, but also as an instrument in defining the best sale price for their fruit ( $\mathrm{R} \$ / \mathrm{kg})$, from which profits can be forecasted in all levels of refusals. 


\section{INTRODUÇÃO}

Os maiores avanços no desenvolvimento de embalagens aconteceram a partir da revolução industrial, em função da diversidade e quantidade de bens e produtos que passaram a ser oferecidos aos consumidores. A produção em série e em grande escala propiciou a geração de uma demanda muito mais ativa e exigente em qualidade e quantidade, sendo atingida de forma mais completa com o surgimento de supermercados e sistemas de auto-serviço. Aos poucos, a exigência por qualidade passou para o consumo de produtos in natura, dada a preocupação, por parte dos consumidores, quanto à origem dos alimentos (Oliveira et al., 2003).

Nesse sentido, acredita-se que o mercado interno brasileiro poderá observar um consumo crescente de produtos in natura, como frutas, se os mesmos forem oferecidos com qualidade adequada. Essa qualidade está associada a vários aspectos relacionados às atividades de pós-colheita, dentre eles, a embalagem adotada. Cabe salientar que o volume de perdas hortifrutícolas no Brasil, durante o processo de comercialização, é extremamente alto, sendo que uma grande parcela dessas perdas poderia ser evitada com a adoção de embalagens mais adequadas.

Destaque-se também que grande parte das perdas de qualidade dos produtos hortifrutícolas decorre de problemas logísticos, tais como a demora na realização das operações de carga e descarga dos caminhões, a falta de climatização no transporte e armazenamento, a falta de otimização de percursos, as más condições das estradas, as cargas não paletizadas, a inadequação e ainda a falta de padronização das embalagens. 
De acordo com Pichler (2003) ${ }^{1}$, o nível de perdas de hortifrutícolas durante o processo de distribuição da unidade produtora até o consumidor final varia entre $30 \%$ e $40 \%$, que correspondem aos danos mecânicos devido à inadequação das embalagens, condições das estradas, temperatura e nível de maturação das frutas, entre outros. Cabe ressaltar que nessas perdas incluem-se as correspondentes às frutas que deixaram de ser consumidas em função do alto preço de mercado. A CEAGESP ${ }^{2}$ já apresenta perdas estimadas em 1,6\% por mês - equivalentes aos restos de frutas em função de más condições de embalagens e manuseio - ocasionadas durante a comercialização nesta central. Além disso, embalagens não higienizadas propiciam o agravamento de outros problemas, como os de ordem microbiológica, atingindo não somente a qualidade do fruto, mas também a saúde humana.

No caso da laranja, a maior parte da produção brasileira ainda é comercializada em embalagens inadequadas, que prejudicam a manutenção de sua qualidade. Isso ocorre principalmente quando a fruta é transportada em longas distâncias, com e embalagens inadequadas provocando perdas por falta de estabilidade das pilhas e pela própria abrasão. Segundo Ivancko (2002), dados do Instituto de Economia Agrícola (IEA) apontam que, em média, 30\% dos produtos hortifrutícolas produzidos no Brasil não chegam a ser consumidos, contabilizando uma perda anual de US\$ 5.1 bilhões.

No que se refere às normas de embalagens, a Portaria $n^{\circ} 127$, de 4 de outubro de 1991, determinou que as frutas cítricas poderiam ser comercializadas em caixas de madeira ou papelão, ou em sacos de polietileno ou polipropileno. Dessa forma, no Entreposto Terminal de São Paulo da Companhia de Entrepostos e Armazéns Gerais do Estado de São Paulo (CEAGESP), as laranjas costumam ser comercializadas em caixas de madeira contendo aproximadamente $27 \mathrm{~kg}$ de fruta. Atualmente, a Portaria $\mathrm{n}^{\mathrm{o}}$ 62, de 21 de março de 2001, mas que somente entrou em vigor em maio de 2003, estabelece a padronização e higienização de embalagens de hortifrutícolas. Logo, há

\footnotetext{
${ }^{1}$ PICHLER, E.F. (USP. Instituto de Pesquisas Tecnológicas, São Paulo). Comunicação pessoal, 2003.

2 (CEAGESP. Centro de Qualidade em Horticultura - CQH, São Paulo). Comunicação pessoal, 2003.
} 
uma forte tendência de substituição das embalagens de madeira tipo "M" (muito usadas para laranjas) e tipo " $\mathrm{K}$ " (muito utilizadas por tomates) por embalagens de plástico e de papelão, ou até mesmo de madeira, porém, de melhor qualidade (matéria-prima laminada e mais leve), conforme padrões estabelecidos pela Portaria $\mathrm{n}^{\circ} 62$.

Assim sendo, a higiene e a logística passam a ser então fundamentais na seleção de embalagens, incluindo os aspectos relacionados ao fato de essas embalagens serem ou não descartáveis, retornáveis ou paletizáveis.

Torna-se, portanto, importante a avaliação da viabilidade econômica de utilização de diferentes tipos de embalagens para laranja, incluindo a consideração das perdas acarretadas pelo uso das mesmas. Para tanto, deve-se averiguar qual tipo de embalagem é mais adequado para cada tipo de produtor.

\subsection{Objetivos}

O objetivo geral do presente estudo diz respeito à identificação do tipo de embalagem mais viável economicamente para laranja de mesa, produzida e comercializada no Estado de São Paulo, a partir de três estudos de casos. Especificamente, pretende-se:

- determinar os custos relativos ao beneficiamento, embalamento e transporte envolvidos na comercialização da laranja, em três produtores representativos do Estado de São Paulo, por meio de visitas realizadas às propriedades;

- avaliar e comparar esses custos por meio de uma planilha específica, analisandose principalmente o lucro resultante da venda de laranjas de mesa a partir de diferentes tipos de embalagens (madeira, plástico e papelão) e de seus respectivos métodos ou sistemas de utilização (aluguel e compra);

- avaliar economicamente o potencial de utilização dos diferentes tipos de embalagens em cada estudo de caso, no contexto de multicasos. 
Cabe ressaltar que, neste estudo, serão tomados como referências os fluxos entre Packing-Houses e atacadistas, CEASAs ou CEAGESP, assim como os fluxos entre Packing-Houses e supermercados ou hipermercados.

\subsection{Estrutura do trabalho}

Será apresentada, no Capítulo 2, uma revisão de literatura referente ao histórico e definições de embalagens, descrição dos principais tipos de embalagens utilizadas para a laranja de mesa no mercado interno paulista e outros aspectos relacionados ao seu transporte e à sua logística. No Capítulo 3, serão apresentados e discutidos alguns trabalhos sobre estrutura de custos de embalagens para hortifrutícolas, os quais foram tomados como base para a definição da metodologia a ser empregada neste trabalho. O Capítulo 4 traz análises e discussões dos resultados obtidos através da aplicação de uma planilha de custos específica, estabelecida para os três tipos principais de embalagens para laranja de mesa: caixas de papelão ondulado, de plástico e de madeira tipo "M"; e para os seguintes sistemas de uso: descartável, aluguel e retornável. Finalmente, o Capítulo 5 reúne as conclusões obtidas através das análises estabelecidas no Capítulo 4, bem como recomendações sugeridas para trabalhos futuros correlatos. 


\section{REVISÃO DE LITERATURA}

Neste capítulo, será abordado o histórico das embalagens e definições sob a ótica de diversos autores e suas respectivas considerações. Além disso, será retratada, de maneira sucinta, a importância da embalagem como instrumento do marketing. Ainda nesse contexto, serão expostas as principais diferenças entre as embalagens utilizadas para laranja de mesa e os aspectos relacionados à padronização recomendada.

\subsection{Embalagem: histórico e algumas definições}

Segundo Banzato \& Moura (1997), o desenvolvimento da embalagem começa com a origem do homem. Ela foi criada para facilitar o transporte. Os primeiros habitantes da Terra precisavam transportar e armazenar principalmente água e comida, vitais para sua sobrevivência. Foi então que o homem primitivo passou a utilizar crânio de animais, chifres ocos e grandes conchas no transporte de líquidos e no acondicionamento de suas colheitas.

Com o tempo, o uso da embalagem como atrativo ao comprador também foi se consolidando. Além disso, a embalagem passou também a auxiliar no marketing do produto; na distribuição, facilitando o manuseio e a identificação do produto; aos atacadistas, tornando-os capazes de praticar níveis de estocagens mais altos nos armazéns; aos varejistas, favorecendo a localização dos produtos nas prateleiras; e no uso final do produto, proporcionando ao mesmo certas características mais convenientes do ponto de vista do consumidor. 
Conforme International... (1983) $)^{3}$, citado por Cabral et al. (1983), são sugeridas algumas definições para embalagem:

- embalagem é a arte, a ciência e tecnologia de preparar produtos para o transporte e vendas;

- embalagem pode ser definida como um meio de assegurar a remessa do produto ao consumidor final, em condições ótimas e a baixo custo;

- a embalagem deve proteger o que vende e vender o que protege;

- produto e embalagem estão muito relacionados;

- para o consumidor, a embalagem é o produto; é aquilo que ele vê e seleciona dentre um elenco de produtos oferecidos a ele na prateleira do supermercado.

De acordo com Moura (1998), a melhor definição de embalagem é de um sistema, e não simplesmente de um contenedor físico, envolvendo um conjunto interrelacionado de componentes de atividades, constituído de:

- matéria-prima básica (madeira, areia, minérios e produtos químicos);

- operações que conformam os materiais em embalagens ou contenedores;

- operações onde a embalagem é preenchida, quantificada, inspecionada quanto à qualidade e fechada;

- unitização ou outras preparações para distribuição;

- distribuição através de canais, envolvendo estocagem, movimentação e transporte;

${ }^{3}$ INTERNATIONAL packaging news: some packaging definitions. International Packaging News, 1983. 
- esvaziamento da embalagem através do consumo do produto;

- disposição, reutilização ou reciclagem da embalagem.

Shepherd (1993) sugere três funções básicas para a embalagem:

- oferecer uma maneira prática de acondicionar e transportar o produto. Os custos seriam certamente muito mais elevados se tudo tivesse que ser carregado e transportado sem embalagens;

- oferecer proteção ao produto. Todo o desenvolvimento realizado para melhorar o acondicionamento do produto tem como principal função aumentar sua proteção, preservando-o nos diversos processos de manuseio das embalagens;

- ao embalar o produto, ele estará sendo fracionado em unidades menores, porém mais convenientes para vendas nos varejos. A embalagem torna o produto mais atrativo ao consumidor, além de the atribuir maior valor agregado.

Kotler (1998), por sua vez, define embalagem como o conjunto de atividades de design e fabricação de um recipiente ou envoltório para um produto, cujas principais finalidades resumem-se em consumo (venda ou apresentação), distribuição física, transporte, exportação e armazenagem. Além disso, o autor acredita que a embalagem tem se tornado uma potente ferramenta de marketing e que, se for bem projetada, pode criar valor de conveniência para o consumidor e valor promocional ao fabricante.

Rosenbloom (2002) acrescenta que a embalagem é muito mais que uma ferramenta promocional para promover diferenciação do produto e atrair a atenção do consumidor. Ela possui uma importante dimensão de logística, que pode fazer grande diferença na eficácia e na eficiência do sistema logístico. Dessa forma, um produto, cuja embalagem é diferenciada e atraente, possuirá maior apelo se for de fácil carregamento, empilhamento e ocupar o mínimo de espaço nas prateleiras. 
Similarmente, Ballou (2001) destaca a importância da gestão logística no marketing da embalagem. Uma vez que a densidade de um produto é reduzida, obtém-se economia nos custos de embalagem, estocagem e transporte. Com um projeto de embalagem pertinente, podem ser alcançados também custos logísticos mais favoráveis, importantes para o setor de marketing atingir seus objetivos, como o de promover a venda do produto, não somente pelo design, mas também pela praticidade da embalagem.

Já segundo Naday (1991), a embalagem geralmente é vista por parte dos produtores e atacadistas como sendo um detalhe na comercialização de citros. Apesar dessa observação, cabe relatar que a adequada apresentação e a boa capacidade de conservação dos alimentos são atributos que transferem à embalagem grande responsabilidade durante a comercialização, pois deverá preservar a qualidade dos frutos a partir do Packing-House até o destino final.

Embora a literatura apresente diversas definições para embalagens, sob diferentes óticas, tem-se, a partir desses conceitos, um conceito generalista que caracteriza a embalagem como um agente responsável por embalar, proteger e preservar a qualidade do produto ao longo do trajeto a ser percorrido, além de atrair o consumidor de maneira particular, promovendo a venda do produto e, nesse sentido, caracterizandose como um importante instrumento de marketing.

Ainda nesse contexto, há que se ressaltar a importância da embalagem como fator de preservação da qualidade do produto, uma vez que podem ser observados danos nos produtos em função da utilização das mesmas, quando considerados fatores como: longas distâncias, processo de amadurecimento em frutos, custo de aquisição e matériaprima utilizada em sua composição.

Frutos que apresentam processo de maturação após serem colhidos (frutos climatéricos), apresentam maiores índices de perdas durante o transporte. Tais observações foram relatadas por Roy \& Pal (1991), por meio de pesquisas desenvolvidas sobre perdas na colheita e na pós-colheita de mangas, na região da Índia, envolvendo 
fatores como: manuseio, transporte, embalagem e marketing. Os pesquisadores observaram que, durante o transporte, as perdas fisiológicas, como diminuição de peso em frutas verdes (não amadurecidas), correspondiam a 3,68\% e que as perdas durante o processo de maturação das mangas, alcançavam 7,53\%. Com esses dados, os autores concluíram que as perdas durante o transporte de mangas são relativamente maiores quando essas frutas encontram-se em processo de amadurecimento. Neste sentido, a embalagem deve apresentar boa capacidade de circulação interna do ar, de forma que não seja acelerado o processo de amadurecimento, e também boa resistência durante o transporte,a fim de não amassar os frutos, principalmente se estes estiverem em fase de amadurecimento.

De acordo com Seragini (2000), o nível de perdas por avarias durante a distribuição depende das propriedades da embalagem de transporte. Segundo o autor, essas perdas diminuem à medida que o custo da embalagem aumenta. Dessa forma, quanto mais onerosa a embalagem, subentende-se que maior será sua capacidade de preservação do produto embalado.

Por outro lado, a embalagem também poderá desempenhar seu papel de proteção e manutenção da qualidade do produto se tiver em sua composição materiais recicláveis - como a madeira - que possuem baixo custo e, nem por isso, deixam de apresentar alta resistência. A partir dessas considerações, pesquisas conduzidas por Ledermann \& Yount (1992) permitiram observar que a utilização de embalagens recicláveis, além de apresentar baixo preço de aquisição e, em muitos casos, alta capacidade de proteção, contribui para a redução do volume de lixo gerado a partir do descarte de embalagens.

Segundo dados de Controlling... (2003), as perdas causadas em alimentos devido ao tipo de material da embalagem aproximam-se de 1,3\% quando a matériaprima utilizada for correspondente às latas de metal, a $1 \%$ quando a embalagem for de papelão ou plástico e a $0,6 \%$ quando o material da embalagem for vidro. 
Dessa forma, um importante fator a ser considerado no estudo de embalagens é o tipo de material que a compõe. Embora o termo embalagem pareça ser bastante generalista, a matéria-prima utilizada em sua fabricação é um elemento individualizador. Matérias-primas definem tecnologias, custos, estruturas de mercado, finalidade de uso etc. Todos esses elementos são dinâmicos e, periodicamente, embalagens produzidas a partir de novas matérias-primas tomam o lugar de outras longamente estabelecidas. No Brasil, as principais matérias-primas utilizadas pela indústria de embalagens têm sido vidro, metal, madeira, papel, papelão e plásticos.

Na Tabela 1, observa-se a evolução do uso, no Brasil, em termos relativos, de cada matéria-prima na composição de embalagens para os nais diversos setores, no período compreendido entre 1996 e 2002.

Tabela 1. Utilização dos diferentes tipos de matérias-primas para embalagens em 19962002, Brasil.

\begin{tabular}{lccccccc}
\hline $\begin{array}{c}\text { Grupos de } \\
\text { embalagem }\end{array}$ & 1996 & 1997 & 1998 & 1999 & 2000 & 2001 & 2002 \\
\hline Vidro (\%) & 7,13 & 7,23 & 8,41 & 9,54 & 10,03 & 6,70 & 6,40 \\
Metálicas (\%) & 19,02 & 19,01 & 19,95 & 19,14 & 18,22 & 22,30 & 21,00 \\
Madeira (\%) & 1,64 & 1,41 & 1,05 & 0,53 & 0,39 & 1,30 & 1,80 \\
Papel e papelão (\%) & 40,23 & 39,49 & 39,20 & 39,73 & 40,83 & 35,00 & 33,00 \\
Plásticas (\%) & 31,97 & 32,86 & 31,39 & 31,06 & 30,52 & 34,70 & 37,80 \\
Total (\%) & 100 & 100 & 100 & 100 & 100 & 100 & 100 \\
\hline
\end{tabular}

Fonte: ABRE (2003) ${ }^{4}$

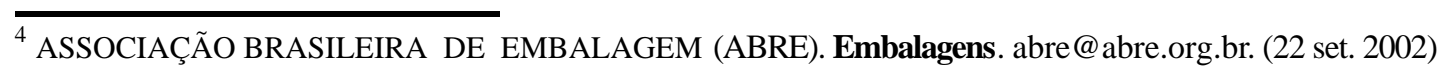


Nota-se que a utilização da matéria-prima madeira sofre progressiva diminuição, recuperando-se a partir de 2001. Os materiais vidro, papel e papelão apresentaram-se praticamente estáveis, com tendências de redução a partir de 2001. Já os materiais metálicos e plásticos, embora tenham demonstrado estabilidade ao longo dos anos, apresentaram relativos aumentos no consumo a partir de 2000. Essa avaliação vem confirmar o avanço desses setores sobre o de vidros, a partir de 2000, principalmente com a utilização da resina plástica PET (para refrigerantes e cosméticos) e do alumínio (para latas de bebidas), conforme pesquisas apresentadas em Setor... (2003).

Já a madeira recupera sua utilização em 2001, quando adquire notoriedade como material de embalagem ambientalmente sustentável, com uma taxa de reciclagem equivalente a 37\%, segundo informações apresentadas em Caixas... (2000). Além das vantagens ambientais de reciclagem (diminuição dos resíduos destinados aos aterros), os resíduos de embalagens de madeira são também úteis para produção de aglomerados de madeira.

\subsection{A importância da embalagem como instrumento de marketing}

A embalagem passou a ser uma poderosa ferramenta de marketing e, se bem desenhada, pode agregar valores de conveniência e promocionais (Oliveira et al. 2003).

Graças a esse fator, o setor supermercadista tem exigido cada vez mais de seus fornecedores, além da qualidade, a apresentação adequada de seus produtos (principalmente alimentos hortifrutícolas), uma vez que a embalagem é a interface direta com o consumidor, promovendo o processo de venda.

Seragini (2003) ressalta que a embalagem deve agradar o consumidor, principalmente quando este se encontra em processo de compra em supermercados pois, $70 \%$ das decisões são tomadas junto à prateleira. Ainda nesse contexto, Seragini (2002) relata que mudanças nas embalagens geralmente significam aumento de vendas desde que estejam em sintonia com a linguagem e o comportamento de seu público-alvo. Cabe 
ressaltar que o design da embalagem é uma das ferramentas mais importantes do marketing no ponto-de-venda, contribuindo não apenas para uma boa apresentação do produto, mas também como um diferencial perante os concorrentes, podendo garantir a atenção do consumidor para a compra.

Dessa forma, Campos \& Nantes (2003) concluíram, por meio de pesquisas sobre a conveniência de embalagens, que as empresas perceberam que a beleza das embalagens e a capacidade das mesmas em preservar as características dos produtos (como sabor e frescor), não são suficientes em um mercado competitivo. Com isso, o conceito de embalagem se ampliou, ganhando status de produto, sendo capaz de comunicar com a mesma linguagem de conveniência onde quer que se localize.

Assim, percebe-se a importância da embalagem como fator de venda do produto, agregando-lhe valor, a partir de estratégias apropriadas de marketing.

\subsection{Embalagens para laranja de mesa no mercado interno brasileiro}

A embalagem mais utilizada para laranja no mercado interno do Estado de São Paulo é a caixa de madeira tipo "M", capaz de acondicionar $27 \mathrm{~kg}$ da fruta e com medidas não paletizáveis: 54 × 29 × $29 \mathrm{~cm}$, sendo o palete-padrão com dimensões de $100 \mathrm{~cm} \mathrm{x} 120 \mathrm{~cm}$. Embora apresente baixo custo de aquisição, principal motivo pelo qual permanece há 30 anos no mercado, esse tipo de embalagem, segundo Ramos (2001), apresenta muitas desvantagens relacionadas às condições de higiene, ergonomia do trabalho, apresentação do produto, limitação no aproveitamento da capacidade de carga líquida do caminhão, além de onerar as atividades de carga e descarga do produto.

Paralelo à hegemonia da caixa de madeira tipo 'M", verifica-se a existência de embalagens de papelão e de plástico no mercado de citros. As primeiras acondicionam de 18 a $20 \mathrm{~kg}$ de laranja, podendo apresentar variações quanto às dimensões e, em consequiência disso, podem ou não ser paletizáveis. Harder (1998) afirma que a utilização das caixas de papelão vem aumentando devido a exigências do setor supermercadista. Quanto às embalagens de plástico, capazes de acondicionar de 14 
a $27 \mathrm{~kg}$ da fruta, embora apresentem alto custo de aquisição, possuem maior facilidade de desinfecção, além de se assemelharem muito com as caixas de madeira, no que se refere ao sistema retornável, podendo ter maior aceitação pelos atacadistas que as caixas de papelão (descartáveis).

Diante desses fatos, Pichler (2001b) acredita na existência de uma grande pressão dos fabricantes de caixas plásticas e de papelão no sentido de que venha a ser proibido o uso das caixas de madeira por não apresentarem estruturas suficientes para higienização. No entanto, o autor considera importante que as caixas de madeira não sejam eliminadas do mercado, não apenas pelo problema social que isso acarretaria (desempregos), mas para que o comprador, ou distribuidor, de hortifrutícolas tenha alternativas econômicas de embalagem à sua disposição. Existem também razões ecológicas que podem vir a promover a caixa de madeira, tendo em vista a sua origem a partir de atividades de reflorestamento.

A legislação que regulamentava embalagens de produtos hortifrutícolas no Brasil era baseada na Portaria n ${ }^{\circ}$ 127, de 1991, que vigorou até 12 de novembro de 2002. Nesta data foi publicada a instituição normativa referente a Portaria $\mathrm{n}^{\circ} 62$, que entrou em vigor em maio de 2003 (180 dias após a sua publicação). Esta portaria deve substituir a anterior, gradativamente, até o final de 2003. Os pontos principais da nova legislação dão conta de que as embalagens deverão ser paletizáveis, ou seja, suas medidas externas devem ser sub-múltiplas do palete padrão brasileiro $(100 \mathrm{~cm}$ x $120 \mathrm{~cm})$, higienizadas quando retornáveis e rotuladas.

Entretanto, as embalagens ainda utilizadas pelos atacadistas da CEAGESP são o reflexo da desorganização do setor e da sua dificuldade com a modernização. Gutierrez (2001) relata que a maioria das embalagens utilizadas é retornável ou reutilizável, não sofrendo nenhum processo de desinfecção, não possuindo medidas paletizáveis e representando fonte de danos ao produtor, além de ser vetor de disseminação de problemas fitossanitários e sanitários. 
Na Figura 1, observa-se a participação dos diversos tipos de embalagens no setor hortifrutícola, utilizados na CEAGESP.

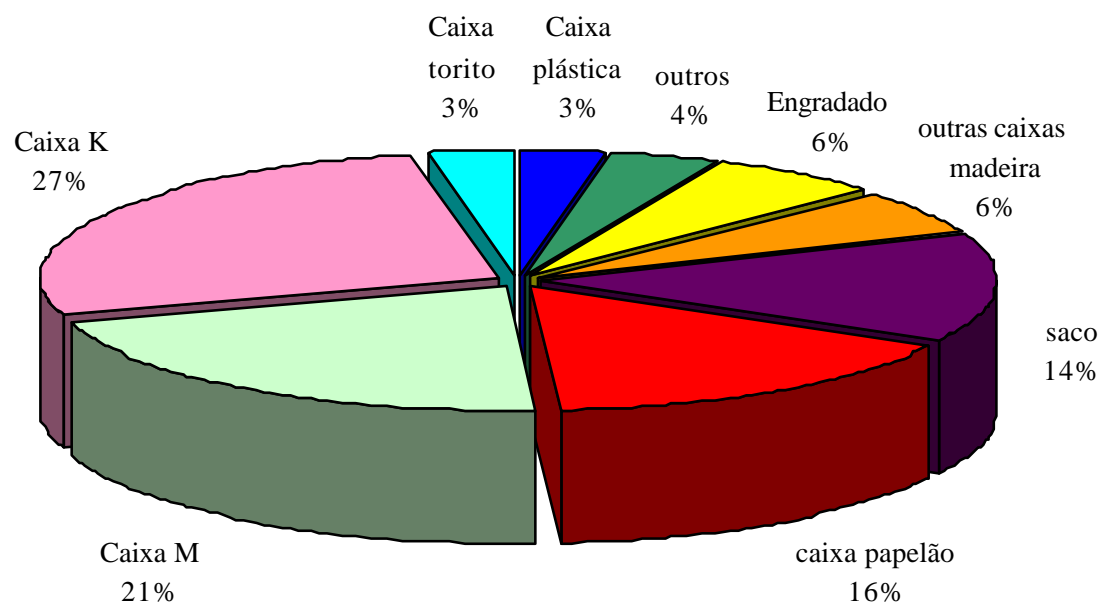

Figura 1 - Participação dos tipos de embalagens na CEAGESP, 2002.

Fonte: CEAGESP (2002)

Confirma-se, pela Figura 1, a hegemonia das caixas de madeira tipos "M" e "K", usadas para laranjas e tomate, respectivamente. As embalagens tipo saco e caixas de papelão apresentam nível de utilização alto, se comparadas com as restantes. As laranjas chegam na CEAGESP em caixas (madeira geralmente) e, devido à exigência de algum varejista, são transferidas para os sacos ou "redinhas", no próprio atacado e, então, transportadas ao destino final. As caixas plásticas, embora apresentem um baixo índice de participação na CEAGESP, equivalente a 3\%, demonstram fortes tendências de crescimento, juntamente com as de papelão, devido às normas de padronização de embalagens, instituídas pela Portaria 62. 


\subsubsection{Embalagens de madeira}

Atualmente, a caixa de madeira tipo " $\mathrm{M}$ " (Fgura 2) é a mais utilizada no segmento citrícola brasileiro. Segundo dados fornecidos pela CEAGESP ${ }^{5}, 21 \%$ das embalagens utilizadas para citros neste local dizem respeito à embalagem de madeira tipo "M".

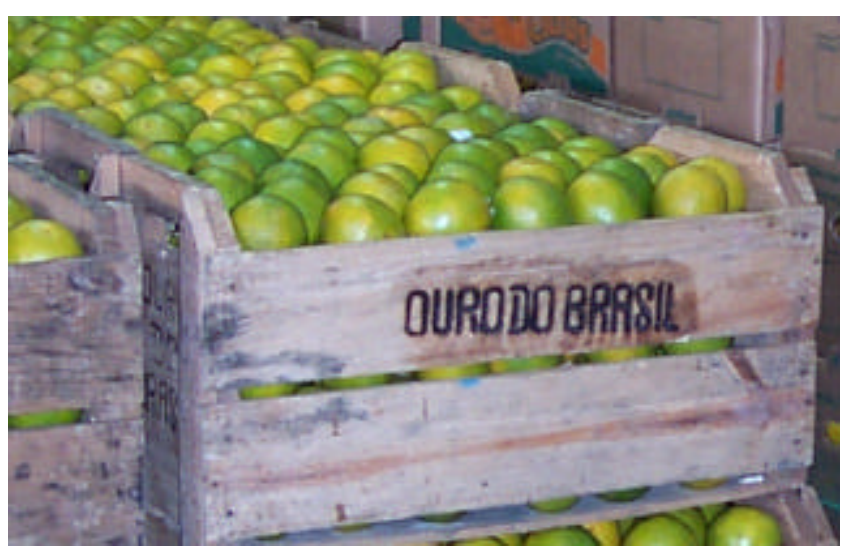

Figura 2 - Embalagem de madeira tipo "M".

Fonte: CEAGESP (2002)

A caixa de madeira tipo "M" possui capacidade para acondicionar $27 \mathrm{~kg}$ de laranja, dimensões não paletizáveis correspondentes a 54 × 29 × $29 \mathrm{~cm}$ e seu preço varia em torno de $\mathrm{R} \$ 3,00$ a unidade.

Chitarra (1994) destaca que as caixas de madeira, em geral, são também as mais utilizadas para acondicionar outras frutas, além da laranja. Costumam apresentar formatos prismáticos e de seção retangular, com dimensões variadas, segundo sua utilização.

\footnotetext{
${ }^{5}$ (CEAGESP. Centro de Qualidade em Horticultura - CQH, São Paulo). Comunicação Pessoal. 2002.
} 
Segundo o mesmo autor, as vantagens de uso deste tipo de embalagem estão relacionadas a:

- resistência e facilidade de manuseio;

- proteção relativa ao produto;

- ventilação adequada;

- custo relativamente baixo.

Por outro lado, conforme enfatiza Pichler (2001b), as caixas de madeira, quando reutilizadas, podem ser dsseminadoras de pragas ou doenças. Portanto, torna-se necessário o estudo de formas de higienização e de tratamento das mesmas, além de um trabalho de educação dos armazenadores e revendedores de caixas vazias quanto às condições higiênicas dos depósitos, quase sempre em estados deploráveis.

Um levantamento realizado pelo Centro de Qualidade em Horticultura (CQH) da CEAGESP, relatado em Onde... (2002), trouxe como exemplo o caso de um dos permissionários de laranja deste mercado atacadista em que as caixas de madeira vazias ocupavam $30 \%$ da área de armazenagem do box, área esta que poderia estar sendo ocupada em sua totalidade com laranjas. Esse estudo mostrou também que tanto os permissionários como os produtores desconhecem o custo de cada embalagem por viagem.

Já a CEASA de Campinas mantém uma área de aproximadamente $13 \mathrm{mil} \mathrm{m}$ somente para o estoque de caixas de madeira. Além do mais, existem dois funcionários e um caminhão encarregados da coleta destas caixas (o caminhão faz em média quarenta viagens por mês). Esta coleta visa basicamente a acabar com as caixas espalhadas ao redor da CEASA, que geram sérios problemas de acúmulo de lixo e desenvolvimento de focos de contaminação. Segundo Benzi (1998a), as caixas entram no atacado e são selecionadas, sendo que aquelas em bom estado de conservação são redistribuídas entre os atacadistas para reaproveitamento, após terem realizado em média cinco viagens; as 
não aproveitáveis são incineradas. Dessa forma, a CEASA-Campinas deseja, além da padronização das embala gens, o fim das retornáveis.

\subsubsection{Embalagens de papelão ondulado}

O papelão ondulado foi introduzido no Brasil em 1935, quando foi instalada a primeira máquina de chapas de papelão para a fabricação de caixas. A oferta desse material foi motivada pela comercialização ascendente de produtos e a consequente demanda de embalagens, trazendo a necessidade de um insumo capaz de competir, em preço e funcionalidade, com as caixas de madeira, largamente utilizadas, principalmente para laranjas.

No caso de caixas de papeño para laranjas (Figura 3), suas dimensões podem variar muito, podendo conter de 18 a $20 \mathrm{~kg}$ da fruta. $\mathrm{O}$ preço da caixa de papelão ondulado para laranja, no mercado interno, é de aproximadamente R \$ 2,40 por caixa, dependendo do volume, tipo de impressão, cor, entre outros.

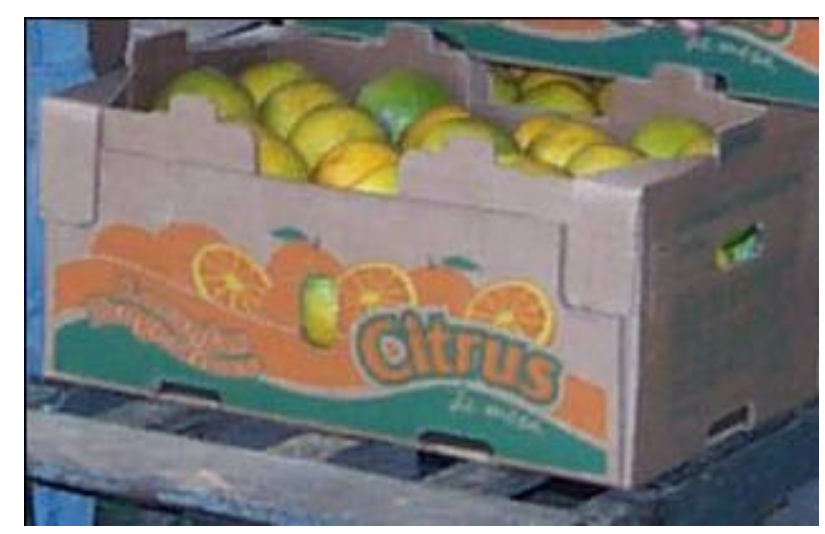

Figura 3 - Caixa de papelão ondulado para laranja.

Fonte: CEAGESP (2002) 
As caixas de papelão ondulado podem ter paredes simples ou múltiplas. Conforme ilustra a Figura 4, nota-se que a estrutura do papelão é formada por um elemento ondulado (miolo) colado em ambos os lados a elementos planos (faces). $\mathrm{Na}$ década passada, essas estruturas, eram muito utilizadas para caixas de hortifrutícolas, e possuíam proteção de parafina como impermeabilizante das faces externas. No entanto, atualmente tal produto não é mais utilizado, conforme acordo das empresas de papelão ondulado com a Associação Brasileira de Papelão Ondulado (ABPO), uma vez que a parafina pode dificultar o processo de reciclagem.

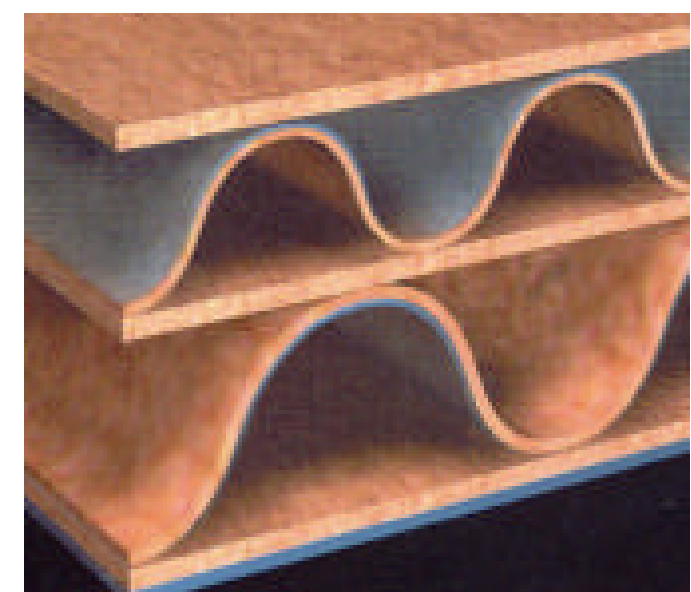

Figura 4 - Papelão ondulado composto por 2 miolos (ondas).

Fonte: Rigesa (2002a)

Quanto ao miolo dessas caixas, este não possuía, até a última década, tratamentos anti umidade e era constituído de material reciclado (baixa resistência), possuindo, assim, alta absorção de umidade. Atualmente, a estrutura destas caixas evoluiu muito. O miolo é constituído de fibras virgens (no caso de embalagens para frutas) e possui tratamentos impermeabilizantes. Isso tudo, conforme descrito em A Logística... (2001), confere resistência e qualidade às caixas de papelão ondulado. Além disso, os modelos mais recentes constituem-se de ondas duplas para melhorar ainda mais a estrutura da embalagem. 
Segundo Schuur (1988), as vantagens conferidas ao uso de caixas de papelão ondulado dizem respeito a:

- baixo peso e fácil manuseio;

- paredes suaves, proporcionando efeito "almofadado";

- podem ter vários designs, embora os recomendados sejam os tamanhos padronizados conforme configuração dos paletes;

- baixo custo de aquisição;

- o material permite impressão, melhorando a aparência, além de permitir a inclusão de etiquetas;

- o descarregamento e unitização das caixas podem ser feitos localmente.

Já conforme ABPO... (1996a), o uso de caixa de papelão é importante ao usuário por possibilitar a utilização do marketing visual, uma vez que a impressão flexográfica permite uma apresentação final muito próxima da obtida no processo offset, comum na impressão do papel e do cartão.

Benzi (1998b) ressalta que a grande vantagem da utilização da caixa de papelão para o sistema logístico é a redução de custos. Na opinião da autora, essa embalagem facilita o controle de estoque e ocupa espaço menor, tanto na área de armazenagem quanto no transporte, reduzindo custos de fretes. Para produtos hortifrutícolas, a eficiência no transporte é elevada, pois enquanto um caminhão transporta 1000 caixas de madeira $(27 \mathrm{~kg})$ com frutos, este mesmo poderá transportar 6000 caixas de papelão $(20 \mathrm{~kg})$ com o mesmo produto.

Piovesan (1987) relata ainda que, com a mesma quantidade de celulose, podem ser fabricadas quatro caixas de papelão contra uma de madeira. 
Por outro lado, segundo Silva (1999), as caixas de papelão possuem custos elevados, tendo sido viáveis apenas para produtos de alto valor e para transporte em longa distância.

As caixas de papelão têm sido bem aceitas pelos supermercados. Estes aumentam cada vez mais as vendas de frutas em suas gôndolas, sendo estas embaladas preferencialmente em caixas de papelão, conferindo-lhes maior higiene, qualidade, atratividade, marca e informações do produto, contidas em etiquetas (Figura 5).

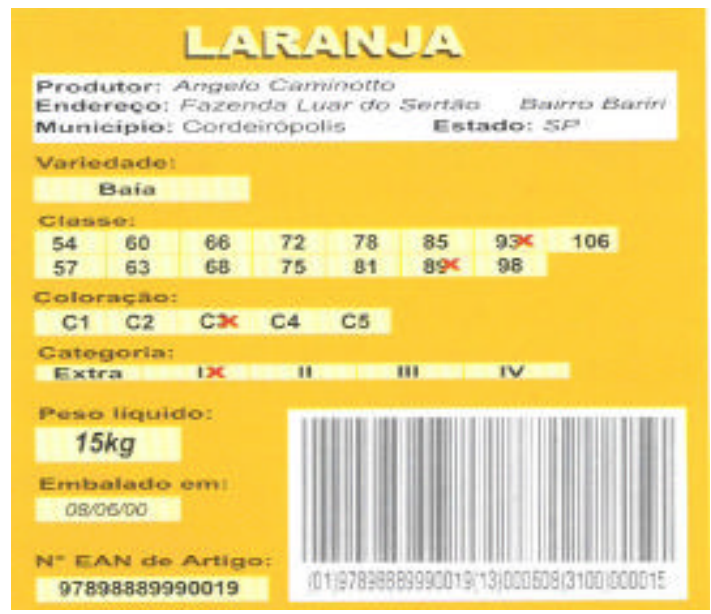

Figura 5 - Etiqueta padronizada para caixas de papelão (laranja).

Fonte: CEAGESP (2002)

As embalagens de papelão são caracterizadas por vários símbolos, que permitem informar, não só ao consumidor sobre características do produto através das etiquetas, mas também informa a todos os agentes da Cadeia de Abastecimento, através de símbolos, o modo de manuseio do produto, se é frágil etc. Isso garante maior rastreabilidade, cada vez mais exigida pelo consumidor (vide Figura 6). 


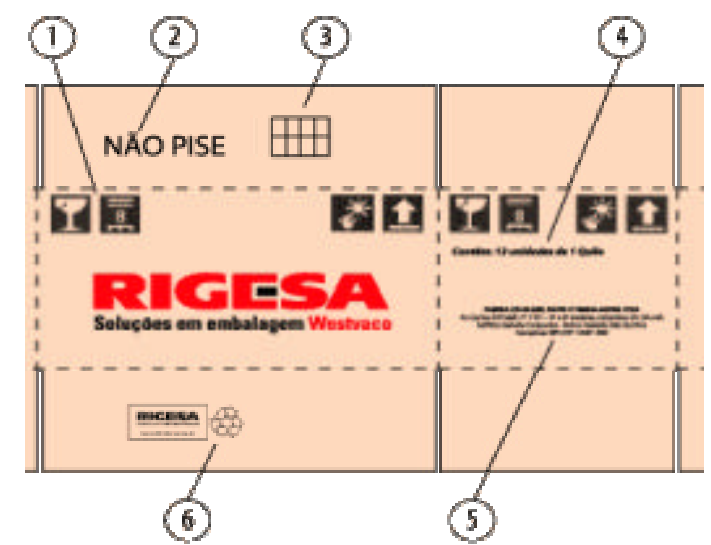

Figura 6 - Marcas e símbolos da caixa de papelão ondulado.

Fonte: Rigesa (2002b)

1) marcas de movimentação

2) aconselhável a impressão de "Não pise" na aba superior

3) paletização

4) peso, conteúdo e outros

5) fabricante do produto-conteúdo

6) selo do fabricante da embalagem

No Brasil, os hortifrutis representam cerca de $10 \%$ do faturamento dos supermercados e, devido a esse valor, esses setores têm dedicado maior atenção às frutas, verduras e legumes, no intuito de aumentar seus lucros. Atualmente, o setor supermercadista tem evitado relacionamento com os atravessadores, sendo que as grandes redes de supermercados já suprem $80 \%$ de suas necessidades com aquisições diretamente vindas dos produtores (Gorenstein, 2000). 


\subsubsection{Embalagens de plástico}

Os plásticos foram introduzidos na fabricação de embalagem no pós-guerra e englobam, entre outros, filmes, sacos tubos, engradados e caixas. As embalagens de plástico podem ser moldadas em vários formatos e, se comparadas a outros materiais, são mais leves, porém não como as de papelão. Costumam apresentar baixa resistência ao calor e permitem certa difusão de gases, vapor e sabores (Embalagens,... 2002). No caso da laranja, as caixas de plástico se assemelham às de madeira, por serem retornáveis.

Segundo Schuur (1988), os materiais das caixas plásticas são constituídos de polietileno de alta densidade ou de polipropileno. O polietileno tem grande força de impacto e baixa degradação diante do raio ultravioleta, enquanto o polipropileno tem maior resistência contra arranhões. O desempenho de ambos materiais pode ser melhorado através da adição de antioxidantes e protetores de ultravioleta (UV) da luz solar.

Conforme o autor, esses tipos de caixa:

- são fortes, rígidas, resistentes a várias jornadas;

- têm custo por jornada relativamente baixo;

- apresentam tamanhos e formas variados, atendendo às necessidades dos mais diferentes clientes, podendo ser de várias cores, permitindo identificação na comercialização;

- são resistentes às variações climáticas.

Quanto às desvantagens advindas da utilização das embalagens plásticas, observa-se, conforme Schuur (1988):

- que a superfície muito rígida pode danificar o fruto, sendo aconselhado o uso de "bandejas" auxiliares; 
- alto custo de aquisição;

- alto risco de extravios e roubos;

- que, por serem retornáveis, tais embalagens podem significar custo extra relacionado à viagem de retorno, lavagem e higienização.

Entretanto, de acordo com Silva (1999), os custos das caixas de plástico têm se reduzido devido à instalação de fábricas de embalagens estrangeiras no Brasil. Tais caixas oferecem uma vantagem adicional: não é necessário imobilizar capital na aquisição destas, pois os fabricantes também oferecem a alternativa de sistema de arrendamento de embalagens. Algumas redes de supermercados também oferecem as embalagens plásticas aos produtores para transporte dos produtos adquiridos. Neste caso, o produtor se responsabiliza pelo custo de uma taxa de uso das caixas.

As embalagens plásticas destinadas ao acondicionamento de laranjas possuem capacidade de 14 a $18 \mathrm{~kg}$, cujo custo varia de $\mathrm{R} \$ 7,00$ a $\mathrm{R} \$ 8,00$ a unidade (vide Figuras 7 e 8). Em geral, são mais caras que as embalagens de madeira e de papelão, porém, são mais rígidas e os custos correntes são relativamente baixos. As embalagens plásticas facilitam o mercado e preservação das frutas, pois são de fácil higienização. 


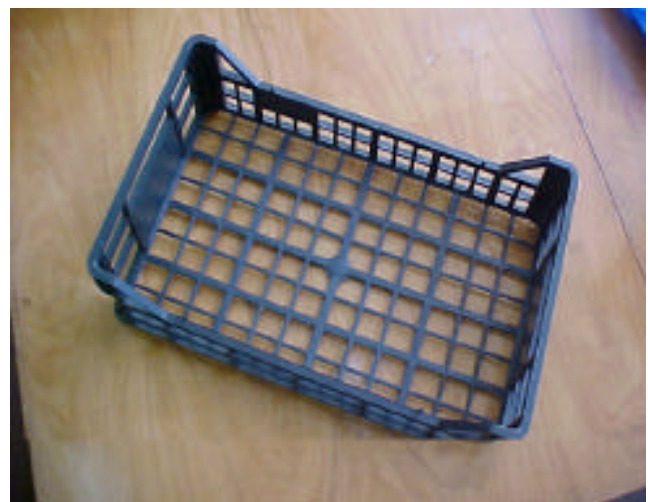

Figura 7 - Embalagem de plástico excessivamente aberta no fundo.

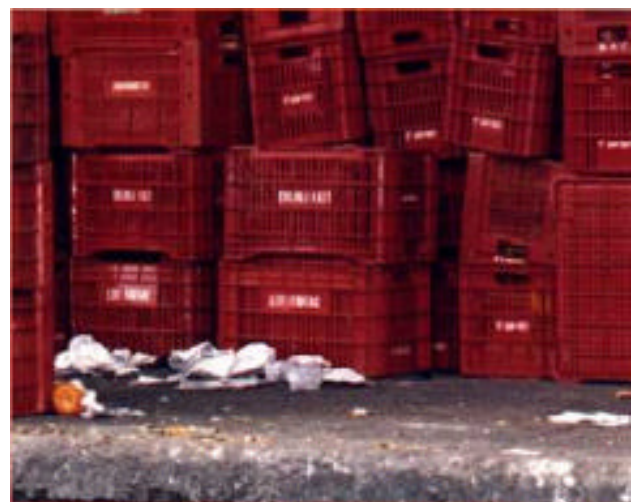

Figura 8 - Embalagem de plástico.

Fonte: A logística...(2001)

Fonte: Pichler (2001b)

A partir das considerações sobre os principais tipos de embalagens para laranja de mesa, têm-se, para melhor compreensão e análise, uma síntese das respectivas características, apresentada na Tabela 2. 
Tabela 2. Principais diferenças entre caixas de madeira, de plástico e de papelão, 2003.

\begin{tabular}{|c|c|c|}
\hline Caixas de Papelão & Caixas de Madeira tipo "M" & Caixas plásticas \\
\hline Paletizáveis & $\begin{array}{l}\text { Não paletizáveis (sendo carregadas uma a } \\
\text { uma) }\end{array}$ & Podem ou não ser paletizáveis \\
\hline $\begin{array}{l}\text { Resistência e tamanho adequados e } \\
\text { relativos ao empilhamento. }\end{array}$ & $\begin{array}{l}\text { Grandes e pesadas para empilhamento } \\
\text { (provocam esmagamento dos frutos da } \\
\text { camada inferior da pilha) }\end{array}$ & $\begin{array}{l}\text { Leves, se comparadas às de madeira, e } \\
\text { resistentes }\end{array}$ \\
\hline $\begin{array}{l}\text { Exigem baixo no de mão de obra durante } \\
\text { manuseio (são paletizáveis) }\end{array}$ & $\begin{array}{l}\text { Exigem maior } n^{\circ} \text { de mão de obra durante } \\
\text { manuseio }\end{array}$ & $\begin{array}{l}\text { O no de mão-de-obra dependerá se for } \\
\text { paletizável ou não }\end{array}$ \\
\hline- & Difícil higienização & Fácil higienização \\
\hline Descartáveis e recicláveis & Reutilizáveis & Reutilizáveis \\
\hline $\begin{array}{l}\text { Ocupam o mínimo de espaço possível, } \\
\text { sendo "montadas" apenas no momento de } \\
\text { embalagem dos produtos; São empilhadas } \\
\text { sob forma de "lâminas", otimizando o } \\
\text { espaço }\end{array}$ & $\begin{array}{l}\text { Ocupam muito espaço no Packing - House, } \\
\text { principalmente ao serem armazenadas para } \\
\text { reparo, dificultando toda a logística do } \\
\text { processo da unidade de armazenamento }\end{array}$ & $\begin{array}{l}\text { Ocupam espaço no Packing -House, } \\
\text { porém de fácil administração, se } \\
\text { considerado o sistema de aluguel }\end{array}$ \\
\hline $\mathrm{R} \$ 2,00$ a $\mathrm{R} \$ 2,40$ a unidade & De $R \$ 2,50$ a $R \$ 3,00$ a unidade & $\begin{array}{l}\text { De } R \$ 7,00 \text { a } R \$ 8,00 \text { a unidade } \\
\text { reciclada e de } R \$ 10,00 \text { a } R \$ 12,00 \text { a } \\
\text { unidade de material virgem }\end{array}$ \\
\hline \multirow[t]{2}{*}{ Capacidade de 18 a $20 \mathrm{~kg}$ de laranja } & Capacidade de 25 a $27 \mathrm{~kg}$ de laranja & Capacidade de 20 a 27 kg de laranja. \\
\hline & $\begin{array}{l}\text { Nível de perdas de embalagens retornáveis: } \\
10 \% \text {. }\end{array}$ & $\begin{array}{l}\text { Nível de perdas de embalagens } \\
\text { retornáveis: menor que } 2 \% \text {. }\end{array}$ \\
\hline $\begin{array}{l}\text { Nível de perdas de frutos beneficiados } \\
\text { correspondente ao uso da embalagem para } \\
\text { uma carga de caminhão truck (12 a } 13 \\
\text { toneladas): praticamente nula, } \\
\text { aproximando-se de } 2 \% \text { para distâncias } \\
\text { percorridas acima de } 1000 \mathrm{~km} \text { (devido } \\
\text { dificuldade de circulação interna do ar) }\end{array}$ & $\begin{array}{l}\text { Nível de perdas de frutos beneficiados } \\
\text { correspondente ao uso da embalagem para } \\
\text { uma carga de caminhão truck ( } 12 \text { a } 13 \\
\text { toneladas): praticamente nula, aproximando- } \\
\text { se de } 10 \% \text { para distâncias percorridas acima } \\
\text { de } 1000 \mathrm{~km} \text {, (em função das más condições } \\
\text { das estradas e da falta de estabilidade de } \\
\text { pilha) }\end{array}$ & $\begin{array}{l}\text { Nível de perdas de frutos beneficiados } \\
\text { correspondente ao uso da embalagem } \\
\text { para uma carga de caminhão truck ( } 12 \\
\text { a } 13 \text { toneladas): praticamente nula }\end{array}$ \\
\hline Baixa ventilação interna & Média ventilação interna & Alta ventilação interna \\
\hline São mais higiênicas & $\begin{array}{l}\text { Raramente passam por processos de limpeza } \\
\text { ao serem retornáveis, provocando presença } \\
\text { de fungos, que deterioram produtos por elas } \\
\text { embalados }\end{array}$ & $\begin{array}{l}\text { Passam por processos de limpeza ao } \\
\text { serem retornáveis, evitando presença de } \\
\text { microorganismos prejudiciais ao fruto e } \\
\text { à saúde humana }\end{array}$ \\
\hline $\begin{array}{l}\text { Muito utilizadas para laranja destinada à } \\
\text { exportação ou, quando no mercado } \\
\text { interno, destinada a mercados muito } \\
\text { distantes }\end{array}$ & $\begin{array}{l}\text { A questão cultural aliada ao baixo custo e à } \\
\text { capacidade de retorno fazem com que sejam } \\
\text { as mais utilizadas pelos produtores de laranja, } \\
\text { embora reconheçam que algumas } \\
\text { características não sejam adequadas }\end{array}$ & $\begin{array}{l}\text { Muito utilizadas no mercado interno de } \\
\text { laranja, principalmente quando a fruta } \\
\text { for destinada ao setor supermercadista }\end{array}$ \\
\hline
\end{tabular}

Fonte: dados fornecidos pela Rigesa Celulose, Papel e Embalagens Ltda. e produtores de citros, 2003. 


\subsection{Padronização de embalagens}

Pichler (2001a) salienta que o Laboratório de Embalagem e Acondicionamento (LEA) do Instituto de Pesquisas Tecnológicas (IPT) tem trabalhado, no Brasil e em outros países como México, Cuba e Tailândia, no desenvolvimento de embalagens mais especializadas, tendo em vista uma série de problemas ocorridos na exportação de hortifrutícolas. Tais problemas representam perdas consideráveis para os exportadores e também para a imagem do país exportador.

A falta de um padrão comercial para produtos in natura dificulta a colocação das frutas brasileiras no mercado externo, em especial na Europa. Garcia (2001) defende a organização do setor frutícola nacional a partir da qualificação da mão-de-obra e de um sistema de padronização.

Conforme o mesmo autor, ao contrário do que ocorre na Espanha e demais países europeus, a inexistência de uma política centralizada para o segmento hortifrutícola no Brasil não permite estabelecer padrões. Portanto, de acordo com Garcia (2001), seria interessante o País se preocupar com treinamento de mão-de-obra para classificação das frutas (tamanho ou calibre, local de origem, espécie etc). Além disso, a padronização das embalagens contribuiria muito para a manutenção da qualidade da fruta e aceitação desta pelo mercado externo.

Garcia (2001) relata que, na Espanha, os dados sobre as frutas encontram-se classificados a partir de um sistema de categorias, sendo regulados e controlados pelos Mercados Centrais de Abastecimento S.A. (MERCASA). Logo, uma laranja pode ser classificada no padrão extra, $1^{\mathrm{a}}$ ou $2^{\mathrm{a}}$ categorias. Por exemplo, o consumidor pode comprar uma fruta com rótulo vermelho, que equivale à categoria extra.

Assim, com padrões comuns de classificação de frutas e embalagens, há maior facilidade de inserção das frutas na França, Itália e Inglaterra. Baseado nisso, Garcia (2001) acredita na realização da "agricultura contratável", em que a produção está voltada para as necessidades do mercado, com previsões de quantidade e segurança 
na qualidade das frutas. Para o autor, um País como o Brasil, capaz de direcionar $75 \%$ das suas exportações de frutas para a Europa, deveria adotar um sistema de qualidade para atender às expectativas particulares daquele mercado.

Para o sucesso de sua inserção em mercados externos, o Brasil deve estar atento às normas de padronização de vários países e nelas se basear, para a manutenção da qualidade de seus produtos. Uma das normas principais refere-se à padronização de embalagens para frutas, mais especificamente a laranja, devido ao alto volume exportado.

Figueiredo et al. (1978) relatam que, em países desenvolvidos, o uso de embalagens de madeira para a comercialização de frutas e hortaliças é menos comum que as de papelão, o que evita os inconvenientes de se utilizar embalagens retornáveis, responsáveis por problemas de ordem higiênico-sanitária. Esse conceito continua válido atualmente, porém com maior rigor. Tanto que, em se tratando de frutas in natura, as embalagens de papelão são as exigidas para exportação de laranjas, por exemplo.

A rejeição das caixas de madeira, por parte de muitos importadores no acondicionamento de hortifrutícolas, e a preferência pelas caixas de papelão ondulado se devem ao fato de estas serem facilmente recicláveis e convenientes. Conforme ABPO... (1996b), na utilização das caixas de madeira, observam-se alguns inconvenientes, como perdas das frutas transportadas e má higienização, facilitando a impregnação de fungos e bactérias na madeira, quando utilizada no transporte de um fruto.

O uso de embalagens de papelão ondulado para frutas nos atuais sistemas de distribuição deve atender a alguns requisitos, como: resistência, estabilidade, bom desempenho em condições de umidade, menor peso, espaço para rotulagem e marca, higiene e respeito ao meio ambiente.

Segundo ABPO... (1996b), foi estabelecido nos Estados Unidos um conjunto de critérios e regras para uma perfeita especificação do papelão ondulado. Isso ocorreu 
devido ao intercâmbio permanente entre representantes da área de transportes, fabricantes e até mesmo responsáveis do setor de seguros. No Brasil, ao contrário, as especificações de embalagens produzidas com papelão ondulado se desenvolveram conforme o tipo de usuário, sendo que cada um instituiu seus próprios critérios. Um exemplo disso são as embalagens destinadas ao setor hortifrutícola, desenvolvidas por um grupo de trabalho responsável por projetar e desenvolver embalagens para esse segmento. Esse grupo foi criado pela Associação Brasileira de Papelão Ondulado (ABPO) e inclui, além de técnicos dessa associação, representantes da CEAGESP, do Instituto de Pesquisas de Alimentos (ITAL), do governo e fabricantes de paletes.

Moner (1993) relata a situação das embalagens de hortifrutícolas na Espanha, ressaltando que esta não deve ser analisada como um fator exógeno ao produto. Além disso, a embalagem não deve ser analisada somente como um fator da logística de transporte, na racionalização de custos de hortifrutis, mas também sob o ponto de vista de seu marketing. Logo, o desenvolvimento do conceito "embalagem" deve ser associado a um mercado hortifrutícola moderno, juntamente a um conceito de preservação ambiental.

Conforme o último autor citado, a responsabilidade ambiental tem se desenvolvido muito na Europa. Assim, a utilização das caixas de madeira para frutícolas sofreu uma grande queda, implicando o aumento da utilização de caixas plásticas e de papelão, sendo as primeiras preferidas na Espanha. Mesmo assim, a previsão para o mercado europeu é de crescimento no setor de embalagens de papelão, sendo que a taxa de crescimento deste material tem crescido de forma significativa. O uso de caixa de papelão para citros, entre 1988 e 1989, correspondeu a 6\% e em 1992, chegou a aproximadamente 33\%. Alguns setores do mercado europeu defendem a utilização do plástico na fabricação de embalagens para hortifrutis. Eles garantem um maior futuro para essas embalagens devido ao design adequado, não requerendo desafios de projeções, além de proporcionarem uma ótima rentabilidade (são retornáveis). No entanto, existem também outros setores que defendem a madeira como tipo de material adequado às embalagens desses produtos, devido: 
- à maior tradição no setor hortifrutícola;

- à composição natural e renovável;

- à reciclagem através de trituração e compactação.

Até a década de 1990, o Brasil não dispunha de condições para exportar laranjas em caixas de papelão ondulado, em decorrência de sua fragilidade diante do excesso de peso e das variações climáticas durante o transporte. Atualmente, desenvolveram-se pesquisas e tratamentos aplicados ao papelão que superam esses problemas. No Brasil, a utilização dessas embalagens para laranja e/ou frutas em geral vem sendo amplamente disseminada devido às condições sanitárias.

Segundo Piovesan (1987), outros países como Honduras, Guatemala e Israel, possuem grande desenvolvimento no setor de embalagens para hortifrutis. Israel, grande produtor mundial de frutas, possui sistemas de embalagens muito desenvolvidos devido aos investimentos em pesquisa e tecnologia, como, por exemplo, redução de tamanho de frutas, para um melhor aproveitamento do espaço das embalagens, reduzindo ou até mesmo evitando perdas.

Banzato (2001a) ressalta que embalagens de exportação freqüentemente estão expostas a maior movimentação e variação de temperatura e umidade. A redução do volume, por sua vez, é mais importante para embalagens que percorrem longas distâncias. O tipo de jornada precisa ser considerado, envolvendo identificação dos idiomas e símbolos necessários. As embalagens de exportação precisam corresponder às normas internacionais e regionais, pois a legislação varia entre países. Outro fator que varia entre países é o padrão de cores da embalagem (Figura 9). 


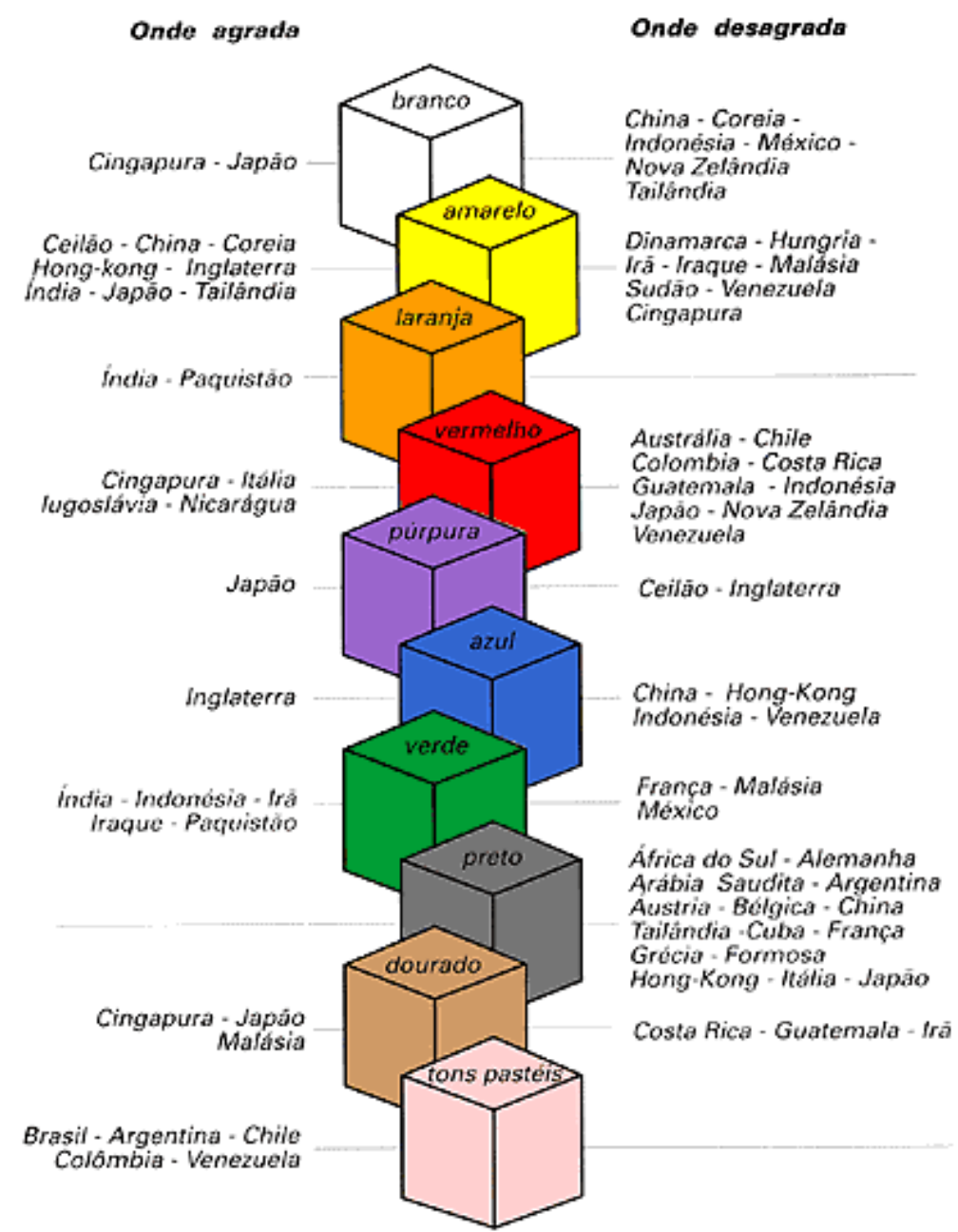

Figura 9 - Cores de embalagens de exportação e preferências de cada país.

Fonte: Rigesa (2002c)

Conforme a Figura 9, observa-se também que as cores das embalagens possuem diferentes significados para os variados países.

Segundo Banzato (2001a), a embalagem para hortifrutícolas destinada aos países em desenvolvimento pode atender a necessidades distintas, uma vez que se sujeita às más condições de transporte e/ou estocagem, ficando expostas ao clima e às pragas, à alta umidade e temperatura variável. Em alguns países desenvolvidos, o autor estima que 
perdas relacionadas aos alimentos in natura variam de 40 a $60 \%$, sendo que metade deste valor poderia ser evitada com uso de embalagens adequadas.

Ainda de acordo com Banzato (2001b), a legislação alemã, implementada em 1993, exige que as embalagens, ao longo do processo logístico, sejam devolvidas ao fornecedor, para reciclagem ou reutilização. Algumas empresas de reciclagem podem ser pagas previamente pelo fornecedor. Assim, em 1991, cerca de $80 \%$ das embalagens alemãs utilizadas no transporte (paletes, contenedores e caixas, por exemplo) foram recicladas. Já nos Estados Unidos, em 1994, 63\% das caixas de papelão ondulado foram recicladas.

No Chile, onde a produção anual de embalagem chega a 900 mil toneladas, Benzi (1998a) declara que é aconselhável reutilizar, reciclar e reduzir o peso, minimizando os custos de exportação dos hortifrutis desse país. Nos Estados Unidos, segundo o mesmo autor, a maioria das caixas de madeira é desmontada e incinerada após o uso e as caixas de papelão seguem leis ambientais que determinam a utilização de materiais recicláveis em sua confecção.

Desde 1990, aproximadamente $40 \%$ do papelão produzido na Itália é reciclado. Benzi (1998a) ressalta que as caixas de papelão têm um considerável valor comercial, sendo que o material nobre é utilizado pela indústria de reciclagem para a confecção de papel miolo.

Embora muito utilizado, o papelão não é a única opção em material de embalagem para hortifrutícolas. Benzi (1998a) ressalta que na Holanda, por exemplo, existe uma caixa de madeira laminada extraída de uma árvore especial. $\mathrm{Na}$ Itália, existem projetos para fabricação de caixas de madeira não retornáveis. Atualmente, conforme dados de Reciclagem... (2002), são reciclados $72 \%$ do papelão ondulado consumido no Brasil, contra $21 \%$ dos plásticos rígidos e filmes consumidos.

Gonçalves \& Sousa (1994) salientam que, para se atingir o mercado externo, técnicas de beneficiamento e embalagens de hortifrutícolas devem ser aprimoradas. As 
frutas frescas, mais consumidas pelas exigentes populações das nações mais desenvolvidas, têm um destaque especial por serem apresentadas como produtos diferenciados e, sendo naturais, possuem como suporte uma agressiva estratégia de marketing. Por meio dessas ações, as frutas tornam-se mais populares e são associadas à origem estabelecida e aos procedimentos-padrão de tratamentos específicos de póscolheita.

\subsubsection{Legislação brasileira sobre embalagens para hortifrutis}

Em 14 de outubro de 1991, a Portaria no 127 do Ministério da Agricultura, Pecuária e Abastecimento foi instituída para definir o tamanho das embalagens. Ela normatizou as dimensões e matérias-primas das embalagens já utilizadas pelo mercado e normalizou embalagens de madeira como as caixas "K" (tomate) e "M" (citros), o engradado e caixas "torito" (banana). O objetivo desta Portaria era organizar o mercado, que vendia produto por volume. O problema era que as dimensões das embalagens, responsáveis pela determinação do volume, variavam com o preço do produto. Quanto mais escasso o produto (logo, maior seu preço), menor a embalagem. Essa portaria foi assim estabelecida para sanar esse tipo de problema.

Segundo Gutierrez (2001), foi a Portaria $\mathrm{n}^{\circ} 127$ a responsável pelo estabelecimento da caixa de madeira tipo " $M$ " (M de mercado) para citros e suas respectivas dimensões:

- comprimento: $520 \mathrm{~mm}$;

- largura: $290 \mathrm{~mm}$;

- altura: $290 \mathrm{~mm}$.

A caixa " $M$ " determinou a classificação de mercado, que caracteriza o tamanho do produto pelo número de dúzias na caixa. Gutierrez (2001) exemplifica tal fato através da laranja Pêra que, por sua vez, apresenta algumas classificações de tamanho: 
- 9, 10, 11 e 12 dúzias: são consideradas de tamanho grande;

- 12, 13 e 14 dúzias: são consideradas de tamanho médio;

- 15,16 e 18 dúzias: são consideradas de tamanho pequeno.

Mais recentemente, o Ministério da Agricultura, Pecuária e Abastecimento (MAPA), em 21 de março de 2001, estabeleceu normas gerais para classificar as embalagens em retornáveis e descartáveis. Essas normas foram instituídas em novembro de 2002, entrando em vigor a partir de maio de 2003. Esta portaria, de $\mathrm{n}^{\circ} 62$, que vai substituir gradativamente a portaria correspondente anterior $\left(\mathrm{n}^{\circ} 127\right)$, estabelece que as embalagens retornáveis devem ser higienizadas a cada utilização, e as descartáveis devem ser recicláveis ou passíveis de incineração, sem oferecer risco ao meio ambiente. Conforme relatado em Onde... (2002), ambas devem ter medidas que permitam a paletização e devem ser rotuladas, apresentando no mínimo as informações obrigatórias sobre o produto embalado, como, por exemplo, o responsável pelo produto, peso líquido e a data do embalamento. A Instrução Normativa instituída em novembro de 2002, referente à Portaria $n^{\circ}$ 62, que entrou em vigor 180 dias após sua publicação (maio de 2003), encontra-se no Apêndice 1.

Com a aprovação da Portaria $\mathrm{n}^{\circ}$ 62, as caixas de madeira tipo "M" para laranjas deverão ser substituídas pelas plásticas ou papelão (ambas paletizáveis). Conseqüentemente, poderá ocorrer a resistência por parte dos produtores e atacadistas, devido, por exemplo, ao fato de as caixas plásticas possuírem um custo mais elevado em relação às de madeira.

Outro fator de resistência se deve à reposição de embalagens, pois a maioria dos atacadistas possui um razoável nível de estoque das caixas antigas e o custo de inutilizá-las e repor o estoque com novos tipos de caixas pode ser bastante significativo.

Além disso, há uma grande resistência à Portaria $\mathrm{n}^{\mathrm{o}} 62$ por parte dos funcionários do atacado, devido ao alto índice de desempregos que pode ser gerado com 
o vigor dessa norma. Isso ocorre porque essa Portaria estabelece o uso de embalagens paletizáveis e, como consequência, tem-se o aumento da utilização de empilhadeiras e redução no número de funcionários responsáveis pelo manuseio, carregamento e descarregamento das frutas em caixas tipo "M".

\subsection{Considerações finais}

Neste capítulo foram apresentadas importantes considerações que envolvem os tipos e uso de embalagens para laranja de mesa. No capítulo a seguir, será demonstrado e analisado o método adotado para avaliação de alternativas mais viáveis de embalagens, a partir das quais se obterão resultados para cada estudo de caso considerado nesta pesquisa. 


\section{MATERIAL E MÉTODOS}

Neste capítulo, para melhor compreensão do procedimento metodológico adotado, é realizada uma descrição do ambiente relacionado ao uso das embalagens em estudo, assim como são discutidos alguns trabalhos referentes à estrutura de custos de embalagens para produtos hortifrutícolas, os quais foram utilizados para a definição da metodologia deste trabalho. A partir de então, adotou-se um método científico que fosse compatível com os objetivos e com o problema tratados nesta pesquisa, o que acabou por constituir um estudo de multicasos.

\subsection{Descrição do ambiente}

A embalagem inicia sua participação na cadeia citrícola a partir da colheita das frutas. Durante esse período, são utilizadas sacolas para acondicioná-las, chamadas "sacolas de colheita". Após esse processo, as frutas são alocadas em containers (400 $\mathrm{kg}$ ), carretas apropriadas ou caixas plásticas de $20 \mathrm{~kg}$, sendo então transportadas aos Packing-Houses, locais que possuem por finalidade selecionar (se para consumo in natura ou indústria), classificar, embalar e proporcionar melhores condições de conservação às frutas. Quando as estas são destinadas ao processamento, são transportadas a granel e vendidas em caixas de 40,80 kg (também chamadas de caixaspeso). Nesse caso, seguem diretamente às indústrias, não passando pelo processo de beneficiamento. Segundo Cortez et al. (2002), uma das grandes mudanças ocorridas nos últimos dez anos foi no manuseio das caixas de campo, que eram carregadas manualmente ou lançadas em caminhões, passando a ær substituídas por tubos, cestas e embalagens equivalentes a oito ou vinte caixas, movimentadas mecanicamente. 
Se as laranjas forem destinadas ao consumo in natura, interno ou para exportação, passarão pelo processo de beneficiamento. Nos Packing-Houses, receberão vários tratamentos, podendo ser acondicionadas em caixas de madeira tipo "M" (a grande maioria), de plástico ou de papelão (principalmente para exportação).

A partir dos Packing-Houses, elas se destinam aos mercados atacadistas (CEASAs e CEAGESP) e/ou diretamente aos supermercados e hipermercados. A partir das CEASAs, podem ser vendidas a mercados, feiras livres, ou mesmo para os supermercados e hipermercados (varejo).

Cabe ressaltar que, no mercado interno, a grande maioria das laranjas de mesa é acondicionada em caixas retornáveis de madeira tipo "M", cuja participação na CEAGESP corresponde a $27 \%$ do total de $63 \%$ das embalagens de madeira (torito, caixas tipo $\mathrm{K}$, engradados e outras $)^{6}$. Assim, possuem todas as características indesejáveis pelos supermercados: não são paletizáveis, são anti-higiênicas, pesadas e de difícil rotulagem, entre outras. Isso impulsiona o setor supermercadista a comprar diretamente de alguns Packing-Houses, que possuem sistemas de embalamento em caixas de papelão. Estas satisfazem às exigências dos consumidores, que são higiene, qualidade, boa aparência e rastreabilidade (por meio de marcas e etiquetas muito bem impressas e informativas). Embora em algumas centrais de abastecimento (em Fortaleza, CE, por exemplo) possam existir também caixas plásticas e de papelão, tais locais não permitem uma logística adequada de manuseio, carregamento, descarregamento e higiene das embalagens, ocasionado o processo de perdas das frutas e encurtando as respectivas vidas de prateleira. Esses fatores impulsionam o varejo a comprar diretamente do produtor.

A Figura 10 ilustra o fluxo da caixa de madeira "M" para a laranja. A trajetória "Packing-Houses-atacado-varejo" é realizada mediante o transporte das

\footnotetext{
${ }^{6}$ (CEAGESP. Centro de Qualidade em Horticultura - CQH, São Paulo). Comunicação pessoal, 2002.
} 
laranjas acondicionadas em caixas "M". Já no caminho "Packing-Houses-varejo", as embalagens utilizadas podem ser de plástico, papelão e, na grande maioria, de madeira. Nesse último tipo de rota, alguns agentes do varejo, como supermercados e hipermercados, evitam o intermediário atacadista devido à falta de logística e higiene locais.

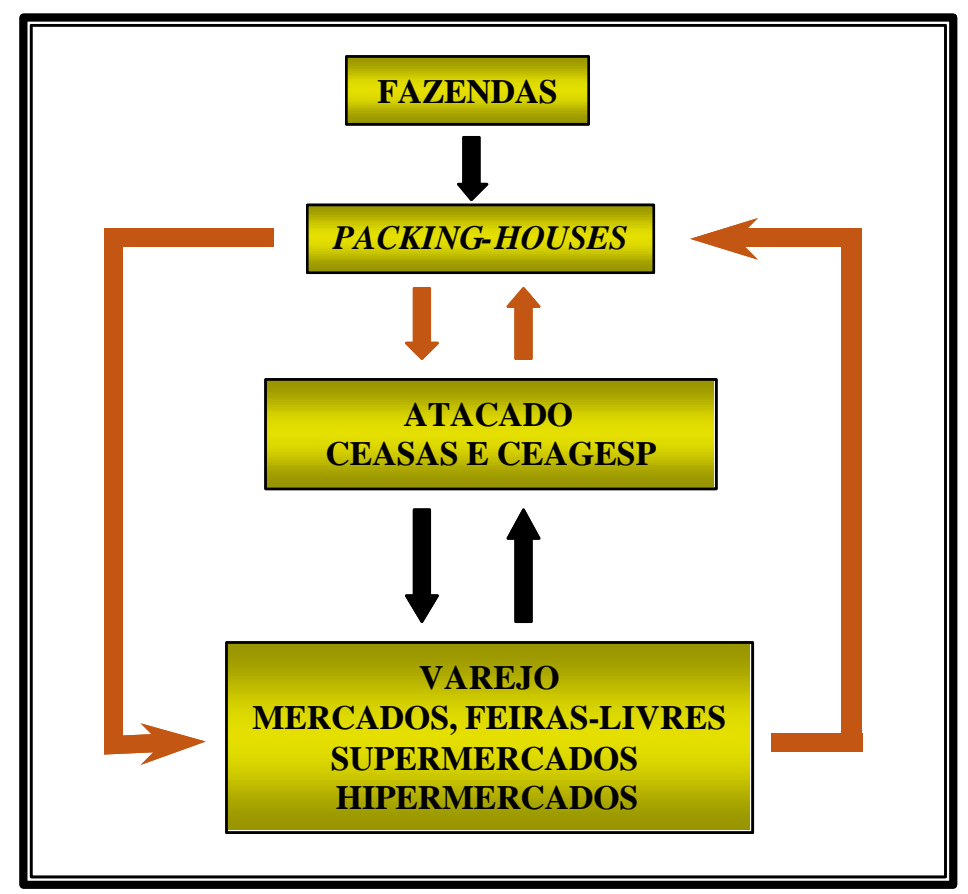

Figura 10 - Fluxo das caixas de madeira tipo "M" no mercado interno de São Paulo.

Fonte: CEAGESP (2002)

Por serem reutilizáveis, as caixas "M" retornarão às CEASAs e, conseqüentemente, aos Packing-Houses, ou diretamente a estes. Porém, geralmente o número de caixas que voltam é menor que o inicial de embalagens.

Pela Figura 10, pode-se ter uma visão do ambiente a ser estudado, ou seja, para esclarecer qual é a embalagem mais viável economicamente sob a ótica de 
utilização (para cada caso estudado), torna-se necessário um estudo dos custos envolvidos durante seu trajeto a partir do Packing-House até o varejo (supermercados, hipermercados, feiras livres e mercados), realizado por um trajeto direto, e também do Packing-House até o varejo indiretamente, passando pelo intermediário (CEASAs e CEAGESP), considerando-se, em ambos os trajetos, o custo envolvido com a perda de embalagens durante o retorno.

Um exemplo capaz de ilustrar a situação descrita anteriormente pôde ser observado em uma visita específica, realizada em setembro de 2001, ao Packing-House "Rafael Juliano", localizado em Porto Feliz, SP.

Esse Packing-House se situa na própria fazenda de Rafael Juliano (unidade produtora de citros) e o produto observado foi a laranja. Tal fruta chega à unidade de armazenamento diretamente do campo, em caixas plásticas. Então, passam por uma seleção por meio do peso e volume, sendo parte delas destinada à exportação (em caixas de papelão), conforme peso e volume exigidos por normas e padrões do mercado externo, e outra parcela, encaminhada ao mercado interno. Após a seleção, as laranjas passam por um tratamento hidrotérmico, seguido de aplicação de cera. Consecutivamente, são embaladas manualmente, sendo aquelas destinadas ao mercado interno colocadas em caixas de madeira tipo "M", grafadas com "RAFAEL JULIANO", cujo logotipo corresponde ao nome do produtor das frutas e proprietário do PackingHouse, e encaminhadas à CEAGESP para comercialização, ou ainda encaminhadas ao varejo diretamente.

\subsection{Métodos de avaliação econômica de embalagens documentados na literatura}

Caixeta Filho (1995) relata, por meio de pesquisas desenvolvidas, que muitas perdas da pós-colheita resultam da utilização de embalagens inadequadas. Além disso, esclarece que alguns projetos da FAO na área de pós-colheita se concentram em recomendar projetos mais eficientes para embalagens, principalmente para produtos mais perecíveis. No entanto, relatourse também que, em muitos casos em que tais 
projetos foram implementados, houve um decréscimo nas quantidades transportadas, embora os produtos tivessem apresentado melhor qualidade.

O uso de embalagem pode apresentar um adicional no preço final do produto, o que pode vir a comprometer a competitividade de produtos bem embalados, de maior qualidade e mais caros, em regiões onde a população possui um nível de renda baixo, sendo que nesse caso a decisão pela compra favorece as mercadorias mais baratas (Caixeta Filho, 1995). Para o autor, talvez esse fato seja um dos componentes formadores da opinião dos produtores de frutas e legumes brasileiros, por exemplo, que insistem na utilização da caixa de madeira para comercialização de produtos agrícolas no mercado interno.

Porém, um estudo realizado na Tailândia, relatado pela FAO (1989) ${ }^{7}$ mencionado por Caixeta Filho (1995), mostra que uma caixa plástica, embora custando por volta de cinco vezes mais que uma com capacidade similar de bambu, pôde ser reutilizada em pelo menos mais vinte viagens, tornando seu custo por viagem quatro vezes menor que o equivalente ao da caixa de bambu.

Há também o trabalho de Crucefix $(1990)^{8}$, também citado por Caixeta Filho (1995), o qual relata, além de análises das perdas físicas por si só, a avaliação da viabilidade econômica da utilização de embalagens adequadas. Nesse caso, a pesquisa foi realizada na República Dominicana, avaliando as diferentes alternativas para o transporte de bananas entre as ilhas desse país. Na Tabela 3, a seguir, pode-se observar que o uso de caixas de papelão é uma alternativa economicamente superior ao transporte a granel, sendo as perdas reduzidas em $25 \%$. Além do mais, existem indícios de que os comerciantes podem aumentar sua lucratividade, não havendo necessidade de pagamento de prêmios pela qualidade. É importante destacar que, conforme Crucefix $(1990)^{9}$, citado por Caixeta Filho (1995), mesmo após intensos trabalhos utilizados para

\footnotetext{
${ }^{7}$ FAO. Prevention of postharvest food losses: fruits, vegetables and root crops: a training manual. Rome, 1989. http://www.fao.org/inpho/vlibrary/t0073e/T0073E00.htm(21 Oct. 2003)

${ }^{8}$ CRUCEFIX, D.N. Plantain (Musa sp) handling improvements in the Eastern Caribbean: the technology is only half of the battle. Acta Horticulturae, n.269, p.401-407, 1990.
} 
sensibilizar a comunidade com esses dados, poucos comerciantes se sentiram efetivamente atraídos em utilizar embalagens de papelão para o transporte de bananas.

Tabela 3. Custos de sistemas de manuseio de banana na República Dominicana.

\begin{tabular}{lcc}
\hline \multicolumn{1}{c}{ ITEM } & GRANEL (EC\$/kg) & CX. PAPELAO (EC\$/kg) \\
\hline Preço pago ao produtor & 110,0 & 110,0 \\
Custo do material descartado & 0,0 & 12,5 \\
Mão-de-obra para empacotamento & 0,0 & 3,4 \\
Custo da embalagem & 0,0 & 20,7 \\
Taxa de estiva & 0,0 & 0,5 \\
Frete & 14,5 & 13,8 \\
Custo de descarregamento & 2,4 & 3,4 \\
Taxa de alfândega entre ilhas & 2,8 & 2,8 \\
Custo de perda em peso & 27,7 & 4,0 \\
Custo de danos físicos & 15,4 & 0,0 \\
Custo do descarte de frutas pequenas & 12,5 & 0,0 \\
TOTAL & 185,3 & 171,0 \\
Preço obtido & 220,0 & 220,0 \\
Resíduo & 34,7 & 48,9 \\
\hline
\end{tabular}

Fonte: Crucefix (1990) ${ }^{9}$, citado por Caixeta Filho (1995)

Nota-se na Tabela 3 que o preço final obtido por quilo de fruta é igual para ambas as alternativas (granel e caixa de papelão). No entanto, o resíduo é maior por quilo de banana quando se considera o uso da caixa de papelão, significando que esta alternativa é, no dado sistema, a mais rentável. Cabe relatar que não serão apenas a aquisição e utilização de embalagens adequadas que proporcionarão o aumento de renda dos produtores, devendo-se, portanto, estar atento aos desperdícios relacionados a cada embalagem.

${ }^{9}$ CRUCEFIX, D.N. Plantain (Musa sp) handling improvements in the Eastern Caribbean: the technology is only half of the battle. Acta Horticulturae, n.269, p.401-407, 1990. 
Figueiredo et al. (1978) realizaram um estudo comparativo do custo de embalagens de madeira tipo " $K$ " e de papelão para a comercialização de tomate. Tal estudo permitiu a análise das vantagens e desvantagens econômicas dessas embalagens. Os autores calcularam os custos das embalagens no transporte do tomate a uma distância de $100 \mathrm{~km}$ (da fazenda à CEAGESP), ilustrados na Tabela 4.

Tabela 4. Custos das embalagens para a comercialização do tomate produzido em Indaiatuba - SP e vendido na CEAGESP, conforme tipo de embalagem, 1976.

\begin{tabular}{|c|c|c|c|c|c|}
\hline \multicolumn{2}{|l|}{ Caixa de madeira } & \multicolumn{2}{|c|}{ Caixa de papelão $n^{0} 1$} & \multicolumn{2}{|c|}{ Caixa de papelão $n^{0} 2$} \\
\hline Itens & $\mathrm{Cr} \$ / \mathrm{cx}$ & Itens & $\mathrm{Cr} \$ / \mathrm{cx}$ & Itens & $\mathrm{Cr} \$ / \mathrm{cx}$ \\
\hline Matéria-prima & 9,785 & Matéria-prima & 10,234 & Matéria-prima & 12,000 \\
\hline Madeira & 9,500 & Papelão & 10,000 & Papelão & 12,000 \\
\hline Pregos & 0,285 & Grampos & 0,234 & & \\
\hline Trabalho & 0,078 & Trabalho & 0,053 & Trabalho & 0,035 \\
\hline Montagem & 0,062 & Montagem & 0,000 & Montagem & 0,000 \\
\hline Fechamento & 0,016 & Fechamento & 0,053 & Fechamento & 0,035 \\
\hline $\begin{array}{l}\text { Transporte da fazenda } \\
\text { à CEAGESP }(100 \mathrm{~km})\end{array}$ & 3,500 & $\begin{array}{l}\text { Transporte da fazenda } \\
\text { à CEAGESP }(100 \mathrm{~km})\end{array}$ & 3,500 & $\begin{array}{l}\text { Transporte da fazenda } \\
\text { à CEAGESP }(100 \mathrm{~km})\end{array}$ & 3,500 \\
\hline $\begin{array}{l}\text { Depreciação das instalações e } \\
\text { equipamentos }\end{array}$ & 0,116 & $\begin{array}{l}\text { Depreciação das instalações e } \\
\text { equipamentos }\end{array}$ & 0,256 & $\begin{array}{l}\text { Depreciação das instalações e } \\
\text { equipamentos }\end{array}$ & 0,088 \\
\hline \multirow[t]{2}{*}{ Barracão } & 0,116 & Barracão & 0,090 & Barracão & 0,088 \\
\hline & & Grampeador & 0,116 & & \\
\hline Impostos (IPI) & 0,000 & Impostos (IPI) & 0,120 & Impostos (IPI) & 0,144 \\
\hline FUNRURAL & 0,245 & FUNRURAL & 0,256 & FUNRURAL & 0,300 \\
\hline Juros sobre capital imobilizado & 0,158 & Juros sobre capital imobilizado & 0,215 & Juros sobre capital imobilizado & 0,245 \\
\hline Matéria-prima & 0,156 & Matéria-prima & 0,207 & Matéria-prima & 0,240 \\
\hline Instalações & 0,002 & Instalações & 0,008 & Instalações & 0,005 \\
\hline Margem (7\%) & 0,685 & Margem (7\%) & 0,716 & Margem (7\%) & 0,840 \\
\hline Total & 14,567 & Total & 15,350 & Total & 17,152 \\
\hline
\end{tabular}

Fonte: Figueiredo et al. (1978)

Verifica-se na Tabela 4 que o item de custo mais oneroso é a matéria-prima, ou seja, $67 \%$ para caixas de madeira e de papelão $\mathrm{n}^{\circ} 1$ e $70 \%$ para caixa de papelão $\mathrm{n}^{\circ} 2$. 
Secundariamente, observam-se os custos com transporte, correspondendo a $24 \%, 23 \%$ e $20 \%$ dos custos para caixas " $\mathrm{K}$ ", caixas de papelão $\mathrm{n}^{\circ} 1$ e caixas de papelão $\mathrm{n}^{\circ} 2$, respectivamente. Esses dois itens somam juntos aproximadamente 90\% do custo total para embalar e transportar o produto a um mercado a $100 \mathrm{~km}$.

Além disso, os autores relatam que a diferença do custo total entre a caixa de madeira e a caixa de papelão $n^{\circ} 1$ é de $5 \%$. Uma diferença significativa ocorre entre os custos dessas duas embalagens com os da caixa de papelão $\mathrm{n}^{\circ}$ 2: tal diferença se aproxima de $18 \%$ entre a caixa " $\mathrm{K}$ " e a caixa de papelão $\mathrm{n}^{\circ} 2$, e $12 \%$ entre a caixa de papelão $n^{\circ} 1$ e caixa de papelão $n^{\circ} 2$. Figueiredo et al. (1978) salientam que essa diferença se deve, principalmente, aos custos das matérias-primas utilizadas.

Ao considerar as perdas do produto em função da embalagem utilizada, Figueiredo et al. (1978) mencionam que as comparações feitas sobre os custos de diferentes tipos de embalagens tornam-se mais completas. Assim, conforme a Tabela 5, as perdas pelas caixas de papelão $\mathrm{n}^{\circ} 1 \mathrm{e} \mathrm{n}^{\mathrm{o}} 2$ são quase três vezes menores que as da caixa "K", para transporte de tomate a uma distância de $100 \mathrm{~km}$. Para a distância de 400 $\mathrm{km}$, as perdas de frutos nas caixas de papelão $\mathrm{n}^{\circ} 1 \mathrm{en}^{\mathrm{o}} 2$ são duas vezes inferiores às da caixa "K". 
Tabela 5. Perdas x custos, de acordo com o tipo de embalagem para tomate.

\begin{tabular}{|c|c|c|c|c|}
\hline Item & Unidade & Caixa K & $\begin{array}{c}\text { Caixa de papelão } \mathrm{n}^{\circ} \\
1\end{array}$ & $\begin{array}{c}\text { Caixa de papelão } \\
n^{\circ} 2\end{array}$ \\
\hline 1. Peso bruto da caixa & $\mathrm{kg}$ & 28,05 & 23,13 & 22,50 \\
\hline 2. Peso líquido da caixa & $\mathrm{kg}$ & 23,60 & 21,93 & 21,40 \\
\hline 3. Perdas físicas em $100 \mathrm{~km}$ & $\mathrm{~kg} / \mathrm{cx}$ & 2,52 & $0,87^{* *}$ & 0,87 \\
\hline 4. Perdas físicas em $400 \mathrm{~km}$ & $\mathrm{~kg} / \mathrm{cx}$ & 3,44 & 1,84 & 1,86 \\
\hline 5. Valor das perdas em $100 \mathrm{~km}^{*}$ & $\mathrm{Cr} \$ / \mathrm{cx}$ & 7,76 & 2,67 & 2,67 \\
\hline 6. Valor das perdas em $400 \mathrm{~km}^{*}$ & $\mathrm{Cr} \$ / \mathrm{cx}$ & 10,59 & 5,66 & 5,72 \\
\hline 7. $\mathrm{N}^{\mathrm{o}}$ de caixas/caminhão de $11 \mathrm{t}$ & Unidades & 392 & 476 & 476 \\
\hline 8. Peso líquido/caminhão de $11 \mathrm{t}$ & $\mathrm{kg}$ & $9.251,20$ & $1.0416,75$ & $1.0186,40$ \\
\hline 9. Valor das perdas/caminhão de $11 \mathrm{t} / 100 \mathrm{~km}$ * & $\mathrm{Cr} \$$ & $3.041,92$ & $1.270,92$ & $1.270,92$ \\
\hline 10. Valor das perdas/caminhão de $11 \mathrm{t} / 400 \mathrm{~km}$ * & $\mathrm{Cr} \$$ & $4.151,28$ & $2.694,16$ & $1.722,72$ \\
\hline
\end{tabular}

Fonte: Figueiredo et al. (1978)

* Preço médio do tomate (produtor) em novembro de 1976: Cr\$ 72,92/caixa de 23,6 kg líquidos

** Considerourse a mesma perda da caixa de papelão $\mathrm{n}^{\mathrm{o}} 2$

$\mathrm{O}$ aspecto mais interessante dos resultados do trabalho de Figueiredo et al. (1978) diz respeito à relação entre perdas e tipo de embalagem, conforme ilustra a Tabela 6. $\mathrm{O}$ valor das perdas acaba por representar um custo agregado ao da embalagem, e, nesse sentido, Figueiredo et al. (1978) concluíram que a embalagem de papelão $\mathrm{n}^{\circ} 1$ apresentou um valor agregado de custos unitários inferior ao das demais embalagens, tanto para o transporte a uma distância de $100 \mathrm{~km}$ como de $400 \mathrm{~km}$. Portanto, apesar do custo mais alto, as embalagens de papelão para tomates, nas condições em que se realizaram tais pesquisas, apresentaram maiores vantagens financeiras, quando se considerou o valor das perdas decorrentes do tipo de embalagem. 
Tabela 6. Valor dos custos e das perdas por tipo de embalagem de tomate, 1976.

\begin{tabular}{lcccc}
\hline & \multicolumn{2}{c}{$100 \mathrm{~km}$} & \multicolumn{2}{c}{$400 \mathrm{~km}$} \\
& $\begin{array}{c}\text { Custo unitário } \\
(\mathrm{Cr} \$ \text { /cx })\end{array}$ & $\begin{array}{c}\text { Custo total } \\
(\mathrm{Cr} \$)\end{array}$ & $\begin{array}{c}\text { Custo unitário } \\
(\mathrm{Cr} \$ / \mathrm{cx})\end{array}$ & $\begin{array}{c}\text { Custo total }^{*} \\
(\mathrm{Cr} \$)\end{array}$ \\
\hline Caixa k de madeira & & & & \\
Custo de embalagem & 14,567 & $1.005 .123,00$ & 16,067 & $1.108 .623,00$ \\
Valor das perdas & 7,787 & $537.303,00$ & 10,630 & $733.470,00$ \\
Total & 22,354 & $1.542 .426,00$ & 26,697 & $1.842 .093,00$ \\
Caixa de papelão ${ }^{\circ} 1$ & & & & \\
Custo de embalagem & 15,350 & $1.139 .798,90$ & 16,850 & $1.251 .179,90$ \\
Valor das perdas & 2,688 & $199.594,75$ & 5,686 & $422.208,24$ \\
Total & 18,038 & $1.339 .393,65$ & 22,536 & $1.673 .388,14$ \\
Caixa de papelão ${ }^{\circ}$ 2 & & & & \\
Custo de embalagem & 17,152 & $1.305 .164,29$ & 18,652 & $1.419 .305,29$ \\
Valor das perdas & 2,688 & $204.540,67$ & 5,747 & $437.312,22$ \\
Total & 19,840 & $1.509 .704,96$ & 24,399 & $1.856 .617,51$ \\
\hline
\end{tabular}

Fonte: Figueiredo et al. (1978)

* Para comercializar as 1628,4 t de tomate produzidas na propriedade estudada

Shepherd (1993), em um estudo correlato, utilizou recursos mais simplificados para o cálculo do custo de utilização de embalagens. Segundo o autor, todos os tipos de embalagens envolvem custos, sendo que o cálculo do custo de embalagem mais fácil de ser determinado ocorre quando a mesma é "one way", ou seja, é usada uma única vez. Embora tal fato seja destacado, o mesmo autor salienta a possibilidade de calcular o custo de embalagens retornáveis.

De forma simples e genérica, Shepherd (1993) calcula o custo de uso de uma embalagem de madeira para laranja, não especificando o tipo da caixa em questão, a partir dos seguintes tipos de dados: 
$a$ é o custo unitário da embalagem;

$b$ é o custo de reparo e limpeza durante a vida útil de cada embalagem;

$c$ é o número de viagens de retorno de cada embalagem;

$d$ é o custo de retorno de cada embalagem.

Logo, tem-se que o custo unitário de utilização da embalagem $(C)$ pode ser dado por:

$$
C=[(a+b) / c]+d
$$

Um exemplo citado pelo autor ilustra o cálculo do custo da embalagem de madeira para laranja, considerando uma unidade de embalagem, cuja capacidade corresponde a $20 \mathrm{~kg}$ de fruta e assumindo os seguintes dados:

$$
\begin{aligned}
& a=\mathrm{US} \$ 10.00 ; \\
& b=\mathrm{US} \$ 2.00 ; \\
& c=10 \text { viagens; } \\
& d=\mathrm{US} \$ 1.00 .
\end{aligned}
$$

Substituindo na expressão (1) os valores citados, Shepherd (1993) concluiu que o custo unitário de utilização da embalagem de madeira para laranja foi de US\$ 2.20 .

O autor ainda ressalta que embalagens mais sofisticadas são recomendadas para reduzir perdas, ao passo que produtos não perecíveis não necessitam destes tipos de embalagens, pois os benefícios acarretados seriam marginais. 
Muraro \& Wardowski (1992) realizaram um estudo para avaliação dos custos envolvidos com o sistema de embalamento para citros em algumas regiões da Flórida. Nesse trabalho, os autores desenvolveram uma planilha para a avaliação de custos utilizando-se de dados fornecidos por Packing-Houses de uva, laranja e tangerina da região. Tais dados referem-se aos custos relacionados ao tipo de material das embalagens, aos custos com mão-de-obra, aos custos diretos (água, luz, reparos e manutenção de materiais) e aos custos indiretos (taxas e depreciação). Com base nessa avaliação, os autores concluíram que a laranja apresentou menor custo envolvido com o sistema de embalamento enquanto a tangerina ficou com o maior, comparando-se com as frutas consideradas na pesquisa, para a região da Flórida.

Já Gutierrez (2001), com o Centro de Qualidade em Horticultura (CQH CEAGESP), realizou um estudo referente ao cálculo do custo de embalagem de madeira para laranja, referente a cada viagem (ou retorno). Nesse caso, a embalagem de madeira considerada refere-se à caixa de madeira tipo " $\mathrm{M}$ ".

Tal pesquisa considerou informações obtidas de vários produtores e atacadistas de laranja, possibilitando o desenvolvimento de uma planilha de custos e conseqüentemente a criação de uma fórmula para o cálculo do custo de utilização da embalagem em questão.

Gutierrez (2001) considerou os seguintes fatores, no desenvolvimento da fórmula referente ao cálculo do custo de uso da caixa tipo "M":

- vida útil da embalagem, mediante o número de viagens suportado pelas embalagens;

- porcentagem referente à perda de caixas por viagem;

- custo do frete da "caixa nova" até o local do primeiro embalamento;

- número de dias necessários para o retorno das caixas; 
- custo do frete de retorno da caixa (a partir do mercado para a produção);

- custo de oportunidade, por meio de custos para manutenção de estoque;

- taxa de juros;

- custo de reparo da caixa por viagem.

Assim, tem-se que a fórmula proposta pela autora citada pode ser dada por:

$X=\{b+e+[(a-1)(1-d)] c+(a-1) d e\} / a+[f(e+b)(g-1)]+h+[f(e+b) i]$

em que:

$X$ é o custo da embalagem por viagem;

$a$ é a vida útil em número de viagens;

$b$ é o valor do frete da "caixa nova";

$c$ é o custo de reparo das caixas por viagem;

$d$ é a porcentagem de perda de caixa por viagem;

$e$ é o valor de aquisição de nova caixa;

$f$ é a taxa "Selic over";

$g$ é o número de dias necessários para o retorno das caixas vazias;

$h$ é o custo do frete de retorno da caixa (a partir do mercado para a produção);

$i$ é a razão entre o nú mero de caixas do sistema e as caixas em estoque de segurança.

Com o desenvolvimento dessa fórmula, Gutierrez (2001) permitiu o cálculo do custo de utilização da embalagem de madeira tipo "M" para laranja.

Como forma de compreensão e especificação do trabalho de Gutierrez (2001), segue-se um exemplo, nas Tabelas 7 e 8, de utilização de planilha de custos para o caso de embalagem de madeira tipo "M" para laranja. 
Tabela 7. Custo da embalagem de madeira retornável, 2001.

\begin{tabular}{lc}
\hline Eventos & Valores \\
\hline Período de retorno das caixas (dias) & 80 \\
Quantidade de viagens & 10 \\
Caixas para reparo do total retornadas (\%) & 10 \\
Perda por viagem (\%) & 10 \\
Preço da caixa (R $\$$ caixa) & 1,2000 \\
Custo do frete da caixa nova (R $\$$ /caixa) & 0,3800 \\
Custo do frete de retorno (R $\$$ caixa) & 0,3800 \\
Custo de reparo (R $\$$ caixa) & 0,0125 \\
Quantidade de caixas em giro & 8.000 \\
Custo das caixas em giro (R\$) & $12.640,00$ \\
Taxa de juros diária sobre o custo das caixas em giro (\%) & 0,0367 \\
Juros diários do custo total de caixas em giro $(\mathrm{R} \$)$ & 4,6350 \\
Juros do estoque em giro (R\$) & 370,81 \\
Custo total com embalagens em 10 viagens $(\mathrm{R} \$)$ & $6.433,25$ \\
Custo total com embalagens em 10 viagens, com juros $(\mathrm{R} \$)$ & $6.804,06$ \\
Quantidade de caixas movimentadas & 10.000 \\
Custo de utilização por caixa de madeira $(\mathrm{R} \$)$ & 0,6800 \\
\hline
\end{tabular}

Fonte: Gutierrez (2001) 
Tabela 8. Custo total com embalagens referentes a 10 viagens, 2001.

\begin{tabular}{lccccccccccc}
\hline Viagem & $1^{\mathrm{a}}$ & $2^{\mathrm{a}}$ & $3^{\mathrm{a}}$ & $4^{\mathrm{a}}$ & $5^{\mathrm{a}}$ & $6^{\mathrm{a}}$ & $7^{\mathrm{a}}$ & $8^{\mathrm{a}}$ & $9^{\mathrm{a}}$ & $10^{\mathrm{a}}$ & $\mathrm{TOTAL}$ \\
\hline Quantidade de caixas & 1.000 & 900 & 900 & 900 & 900 & 900 & 900 & 900 & 900 & 900 & 9.100 \\
Quantidade para completar 1.000 caixas & 0 & 100 & 100 & 100 & 100 & 100 & 100 & 100 & 100 & 100 & 900 \\
Quantidade de caixas de retorno & 900 & 900 & 900 & 900 & 900 & 900 & 900 & 900 & 900 & 900 & 9.000 \\
Quantidade de caixas para reparo & 90 & 90 & 90 & 90 & 90 & 90 & 90 & 90 & 90 & 90 & 900 \\
Custo das caixas novas (R\$) & $1.200,00$ & 120,00 & 120,00 & 120,00 & 120,00 & 120,00 & 120,00 & 120,00 & 120,00 & 120,00 & $2.280,00$ \\
Custo do frete das caixas novas (R\$) & 380,00 & 38,00 & 38,00 & 38,00 & 38,00 & 38,00 & 38,00 & 38,00 & 38,00 & 38,00 & 722,00 \\
Custo do frete de retorno (R\$) & 342,00 & 342,00 & 342,00 & 342,00 & 342,00 & 342,00 & 342,00 & 342,00 & 342,00 & 342,00 & $3.420,00$ \\
Custo de reparo das caixas (R\$) & 1,13 & 1,13 & 1,13 & 1,13 & 1,13 & 1,13 & 1,13 & 1,13 & 1,13 & 1,13 & 11,25 \\
Total (R\$) & $1.923,13$ & 501,13 & 501,13 & 501,13 & 501,13 & 501,13 & 501,13 & 501,13 & 501,13 & $501,136.433,25$ \\
\hline
\end{tabular}

Fonte: Gutierrez (2001) 
Considera-se, a partir dos dados das Tabelas 7 e 8 , que o produtor possui inicialmente 1.000 caixas de madeira e que, a cada viagem de retorno, 100 embalagens são perdidas, ou seja, $10 \%$ da quantidade inicial. Ao final de dez viagens de retorno, totalizando um período de oitenta dias, o produtor estará pagando $\mathrm{R} \$ 0,68$ pela utilização de cada embalagem de madeira.

Por meio do estudo citado, observa-se que o custo de uso da embalagem é bastante significativo, representando 56,6\% do custo de uma embalagem nova. Assim, o custo total de utilização de embalagens, para as dez viagens em questão, representa um expressivo valor de $\mathrm{R} \$ 6.803,65$.

Outra interessante alternativa de se calcular os custos de utilização de embalagem pôde ser observada a partir de visita realizada a três unidades produtoras do Estado de São Paulo, de março a abril de 2003. Foi identificada uma planilha de custo que relaciona os custos referentes ao manuseio, beneficiamento e transporte de laranja de mesa, desenvolvida por um produtor representativo do setor - Fazendas Reunidas Raio de Sol $(2002)^{10}$ - que permite a avaliação do lucro líquido obtido com a venda de laranjas, a partir da utilização de diferentes tipos e sistemas de embalagens. Com o auxílio de tal planilha, pôde-se avaliar qual das embalagens para laranja de mesa é mais viável para a comercialização de um determinado volume de frutas, para determinado produtor.

Das planilhas encontradas na literatura e que foram citadas neste trabalho, a planilha Fazendas Reunidas Raio de Sol, op. cit., foi a que se apresentou mais adequada à metodologia proposta para esta pesquisa. Embora não documentada formalmente na literatura, pôde-se utilizá-la como instrumental metodológico na avaliação de viabilidade de uso de diferentes embalagens, uma vez que já havia sendo empregada para tal finalidade por um dos maiores produtores de citros da região, permitindo, assim, atribuir-lhe um relativo grau de confiabilidade. Para tanto, para não descartar as

\footnotetext{
${ }^{10}$ FAZENDAS REUNIDAS RAIO DE SOL. Cálculo de custos referentes à venda de laranja de mesa, em diferentes níveis de refugo e tipos de embalagens. São Carlos, 2002.
} 
importantes considerações mencionadas por outros autores, optoutse por incluí-las na planilha Fazendas Reunidas Raio de Sol, op. cit., p.50, por meio dos seguintes itens: "despesas com uso de embalagens", "despesas com embalagens retornáveis perdidas", "despesas com carregamento/descarregamento", "despesas com rótulos", "custo de oportunidade da embalagem" e "perdas pelo uso da embalagem". Dessa forma, a partir de um instrumental já bem utilizado em campo, pôde-se complementá-lo com as principais considerações de outros autores e obter uma planilha única e passível de ser utilizada para os diferentes tipos de embalagens e sistemas. A inclusão dos referidos itens foi realizada em comum acordo e com aprovação do autor da planilha Fazendas Reunidas Raio de Sol, op. cit., p.50. A estrutura dessa planilha está reproduzida na Tabela 9, sendo que seus principais itens são detalhadamente descritos a seguir. 
Tabela 9. Planilha de custos ilustrativos de venda de laranja de mesa, em diferentes níveis de refugo e tipos de

embalagens, 2003.

\begin{tabular}{|c|c|c|c|c|c|}
\hline Refugo (\%) & $35.0 \%$ & $30,0 \%$ & $25.0 \%$ & $20,0 \%$ & $15,0 \%$ \\
\hline Perda $(\%)$ & $2,00 \%$ & $2,00 \%$ & $2,00 \%$ & $2,00 \%$ & $2,00 \%$ \\
\hline Indústria (caixas de 40,8kg) & 103,30 & 88,50 & 73,80 & 59,00 & 44,30 \\
\hline Clientes (supermercados ou atacadistas ou CEASAs) - kg de citros & 7.585 & 8.187 & 8.789 & 9.391 & 9.993 \\
\hline Total de laranjas enceradas $(\mathrm{kg})$ & 10.306 & 10.547 & 10.788 & 11.029 & 11.269 \\
\hline \multicolumn{6}{|l|}{ Receitas } \\
\hline Total de Fruta para o Cliente (R\$/caminhão truck) & $\mathrm{R} \$ 5.157,80$ & $\mathrm{R} \$ 5.567,16$ & $\mathrm{R} \$ 5.976,52$ & $\mathrm{R} \$ 6.385,88$ & $\mathrm{R} \$ 6.795,24$ \\
\hline $\begin{array}{l}\text { Total de Fruta para a Indústria (R\$/caminhão truck) } \\
\text { Frete médio Indústria ( } \mathrm{R} \$ \text { /caminhão truck) }\end{array}$ & $\begin{array}{l}\mathrm{R} \$ 826.40 \\
(\mathrm{R} \$ 57.72)\end{array}$ & $\begin{array}{l}\mathrm{R} \$ 708.00 \\
(\mathrm{R} \$ 49.45)\end{array}$ & $\begin{array}{l}\mathrm{R} \$ 590.40 \\
(\mathrm{R} \$ 41.24)\end{array}$ & $\begin{array}{l}\mathrm{R} \$ 472.00 \\
(\mathrm{R} \$ 32.97)\end{array}$ & $\begin{array}{l}\mathrm{R} \$ 354.40 \\
(\mathrm{R} \$ 24.75)\end{array}$ \\
\hline Total das receitas (R\$/caminhão truck) & $\mathrm{R} \$ 5.926 .48$ & $\mathrm{R} \$ 6.225 .71$ & $\mathrm{R} \$ 6.525 .68$ & $\mathrm{R} \$ 6.824 .91$ & $\mathrm{R} \$ 7.124 .89$ \\
\hline \multicolumn{6}{|l|}{ Despesas } \\
\hline Fruta (R\$/caminhão truck) & $\mathrm{R} \$ 3.541,20$ & $\mathrm{R} \$ 3.541,20$ & $\mathrm{R} \$ 3.541,20$ & $\mathrm{R} \$ 3.541,20$ & $\mathrm{R} \$ 3.541,20$ \\
\hline Colheita (R\$/caminhão truck) & $\mathrm{R} \$ 501.67$ & $\mathrm{R} \$ 501.67$ & $\mathrm{R} \$ 501.67$ & $\mathrm{R} \$ 501.67$ & $\mathrm{R} \$ 501.67$ \\
\hline Frete Fazenda_Packing-House (R\$caminhão truck) & $\mathrm{R} \$ 120,00$ & $\mathrm{R} \$ 120,00$ & $\mathrm{R} \$ 120,00$ & $\mathrm{R} \$ 120,00$ & $\mathrm{R} \$ 120,00$ \\
\hline Despesas com uso de embalagens (R\$/caminhão truck) & $\mathrm{R} \$ 84.28$ & $\mathrm{R} \$ 90.97$ & $\mathrm{R} \$ 97.66$ & $\mathrm{R} \$ 104.34$ & $\mathrm{R} \$ 111.03$ \\
\hline Despesas com embalagens retornáveis perdidas ( $\mathrm{R} \$$ /caminhão truck) & $\mathrm{R} \$ 8,43$ & $\mathrm{R} \$ 9,10$ & $\mathrm{R} \$ 9,77$ & $\mathrm{R} \$ 10,43$ & $\mathrm{R} \$ 11,10$ \\
\hline Despesas com carregamento/descarregamento ( $\mathrm{R} \$ /$ caminhão truck) & $\mathrm{R} \$ 0.00$ & $\mathrm{R} \$ 0.00$ & $\mathrm{R} \$ 0.00$ & $\mathrm{R} \$ 0.00$ & $\mathrm{R} \$ 0.00$ \\
\hline Despesas com rótulos ( $\mathrm{R} \$ /$ caminhão truck) & $\mathrm{R} \$ 28.09$ & $\mathrm{R} \$ 30.32$ & $\mathrm{R} \$ 32.55$ & $\mathrm{R} \$ 34.78$ & $\mathrm{R} \$ 37.01$ \\
\hline Beneficiamento ( $\mathrm{R} \$ /$ caminhão truck $)$ & $\mathrm{R} \$ 602,00$ & $\mathrm{R} \$ 602,00$ & $\mathrm{R} \$ 602,00$ & $\mathrm{R} \$ 602,00$ & $\mathrm{R} \$ 602,00$ \\
\hline Intermediação (R\$/caminhão truck) & $\mathrm{R} \$ 103.16$ & $\mathrm{R} \$ 111.34$ & $\mathrm{R} \$ 119.53$ & $\mathrm{R} \$ 127.72$ & $\mathrm{R} \$ 135.90$ \\
\hline Cera ( $\mathrm{R} \$ /$ caminhão truck $)$ & $\mathrm{R} \$ 32,85$ & $\mathrm{R} \$ 33,62$ & $\mathrm{R} \$ 34,39$ & $\mathrm{R} \$ 35,15$ & $\mathrm{R} \$ 35,92$ \\
\hline Frete Packing-House - Cliente (R\$/caminhão truck) & $\mathrm{R} \$ 366.61$ & $\mathrm{R} \$ 395.71$ & $\mathrm{R} \$ 424.80$ & $\mathrm{R} \$ 453.90$ & $\mathrm{R} \$ 483.00$ \\
\hline Despesas Diversas (R\$/caminhão truck) & $\mathrm{R} \$ 37,93$ & $\mathrm{R} \$ 40,94$ & $\mathrm{R} \$ 43,95$ & $\mathrm{R} \$ 46,96$ & $\mathrm{R} \$ 49,97$ \\
\hline Despesas ICMS/frete+ Permissão trânsito (R\$/caminhão truck) & R\$ 43.99 & $\mathrm{R} \$ 47.48$ & $\mathrm{R} \$ 50.98$ & $\mathrm{R} \$ 54.47$ & $\mathrm{R} \$ 57.96$ \\
\hline Despesas Bancárias (R\$/caminhão truck) & $\mathrm{R} \$ 1,26$ & $\mathrm{R} \$ 1,36$ & $\mathrm{R} \$ 1,46$ & $\mathrm{R} \$ 1,57$ & $\mathrm{R} \$ 1,67$ \\
\hline Funrural (R\$/caminhão truck) & $\mathrm{R} \$ 118.63$ & $\mathrm{R} \$ 128.04$ & $\mathrm{R} \$ 137.46$ & $\mathrm{R} \$ 146.88$ & $\mathrm{R} \$ 156.29$ \\
\hline Desconto Financeiro (R\$/caminhão truck) & $\mathrm{R} \$ 154,73$ & $\mathrm{R} \$ 167,01$ & $\mathrm{R} \$ 179,30$ & $\mathrm{R} \$ 191,58$ & $\mathrm{R} \$ 203,86$ \\
\hline Custo de oportunidade da embalagem ( $\mathrm{R} \$ /$ caminhão truck) & $\mathrm{R} \$ 1,12$ & $\mathrm{R} \$ 1,21$ & $\mathrm{R} \$ 1,30$ & $\mathrm{R} \$ 1,39$ & $\mathrm{R} \$ 1,48$ \\
\hline Perdas pelo uso da embalagem (R\$/caminhão truck) & $\mathrm{R} \$ 515,78$ & $\mathrm{R} \$ 556,72$ & $\mathrm{R} \$ 597,65$ & $\mathrm{R} \$ 638,59$ & $\mathrm{R} \$ 679,52$ \\
\hline Total das despesas (R\$/caminhão truck) & $\mathrm{R} \$ 6.261 .73$ & $\mathrm{R} \$ 6.378 .69$ & $\mathrm{R} \$ 6.495 .66$ & $\mathrm{R} \$ 6.612 .62$ & $\mathrm{R} \$ 6.729 .58$ \\
\hline 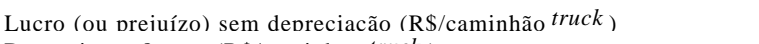 & $(\mathrm{R} \$ 335.26)$ & $(\mathrm{R} \$ 152.99)$ & $\mathrm{R} \$ 30.02$ & $\mathrm{R} \$ 212.29$ & $\mathrm{R} \$ 395.30$ \\
\hline Depreciação 8 anos (R\$/caminhão truck) & $(\mathrm{R} \$ 115,27)$ & $(\mathrm{R} \$ 115,27)$ & $(\mathrm{R} \$ 115,27)$ & $(\mathrm{R} \$ 115,27)$ & $(\mathrm{R} \$ 115,27)$ \\
\hline Lucro (ou preiuízo) líquido (R\$/caminhão truck) & $(\mathrm{R} \$ 450.53)$ & (R\$268.26) & $(\mathrm{R} \$ 85.25)$ & $\mathrm{R} \$ 97.02$ & $\mathrm{R} \$ 280.03$ \\
\hline Valor do quilo de laranja destinada ao cliente, sem depreciação ( $\mathrm{R} \$ / \mathrm{kg}$ ) & $\mathrm{R} \$ 0,72$ & $\mathrm{R} \$ 0,70$ & $\mathrm{R} \$ 0,68$ & $\mathrm{R} \$ 0,66$ & $\mathrm{R} \$ 0,64$ \\
\hline Valor do quilo de laranja destinada ao cliente, com depreciação $(\mathrm{R} \$ / \mathrm{kg})$ & $\mathrm{R} \$ 0,74$ & $\mathrm{R} \$ 0,71$ & $\mathrm{R} \$ 0,69$ & $\mathrm{R} \$ 0,67$ & $\mathrm{R} \$ 0,65$ \\
\hline Valor de venda $(\mathrm{R} \$ / \mathrm{kg})$ & $\mathrm{R} \$ 0,68$ & $\mathrm{R} \$ 0,68$ & $\mathrm{R} \$ 0,68$ & $\mathrm{R} \$ 0,68$ & $\mathrm{R} \$ 0,68$ \\
\hline Lucro (prejuízo), sem depreciação (\%) & $(6,10) \%$ & $(2,67) \%$ & $0,50 \%$ & $3,44 \%$ & $6,18 \%$ \\
\hline Lucro (nreiúzo) com denreciacão (\%) & $(803) \%$ & & & $1.54 \%$ & $4.30 \%$ \\
\hline
\end{tabular}

Fonte: Fazendas Reunidas Raio de Sol, op. cit., p.50. 


\section{- Cálculo das Receitas Totais}

Para fins comparativos, considera-se o mesmo volume de laranjas contido em um caminhão truck ${ }^{11}$, para cada tipo de embalagem. Assim, foram considerados três tipos de embalagens (madeira, plástico e papelão) e quatro planilhas, uma vez que a embalagem plástica demanda duas planilhas devido aos dois possíveis sistemas de utilização: um semelhante ao processo de uso da embalagem de madeira, e outro, correspondente a um sistema de aluguel, cujo gerenciamento é realizado por redes específicas de supermercados e atacadistas.

Para melhor entendimento da planilha, atribuíram-se exemplos de valores relacionados aos itens considerados. Inicialmente, que a carga de um caminhão truck, vindo da fazenda, é contida em 560 caixas plásticas de $21,50 \mathrm{~kg}$, resultando em uma quantidade total de $12.040 \mathrm{~kg}$. A quantidade de laranjas recebidas na unidade de beneficiamento é dada em caixas de 40,80 kg ou "caixas-peso". Essas caixas não existem fisicamente, sendo apenas consideradas como uma unidade de medida utilizada para a venda de frutas para a indústria. Dessa forma, a carga de $12.040 \mathrm{~kg}$ recebida pelo Packing-House é convertida em 295,1 caixas de 40,80 kg.

Outras considerações importantes são o nível de perda de água do fruto por transpiração durante o transporte da fazenda até a unidade de beneficiamento e o nível de refugo (frutas que apresentam manchas e moscas, que depreciam a qualidade do fruto para mesa), equivalentes à carga de laranjas do caminhão truck em questão, também em um trajeto a partir da fazenda até o Packing-House. Logo, pode-se observar nas planilhas níveis de $15 \%, 20 \%, 25 \%, 30 \%$ e $35 \%$ de refugo, sendo que até $25 \%$ da carga total equivale ao nível médio considerado aceitável. Considera-se também que $2 \%$ da carga total equivale ao nível aceitável correspondente à perda de água por transpiração durante o transporte. É importante mencionar que os cinco valores porcentuais de níveis

\footnotetext{
11 Caminhão truck é o veículo que apresenta eixo duplo na carroceria, proporcionando-lhe maior resistência e melhor desempenho. Possui capacidade média de carga entre 12 e 14 toneladas. DICIONÁRIO da logística. http://www.guiadelogistica.com.br/dicionariot-z.htm. (04 nov. 2003)
} 
de refugo são considerados para cada tipo de embalagem. Logo, pode-se avaliar em quais níveis de refugo cada embalagem é mais viável economicamente sob o ponto de vista de utilização, para determinados produtores. Os demais fatores referentes ao cálculo da receita dessa planilha são analisados a seguir, tomando-se como referência o nível de refugo de $25 \%$.

Indústria (caixas de 40,8 kg): do total de frutas que chegam da fazenda $(12.040 \mathrm{~kg})$, aquelas correspondentes ao refugo (25\%, por exemplo) são destinadas à indústria. Para obter esse valor em caixas, divide-se o resultado por 40,80 kg, obtendo-se 73,8 caixas-peso.

Clientes (supermercados, atacadistas ou CEASAs) - kg de citros: as frutas que são isentas de serem classificadas como refugo e que não apresentaram perda de água durante o trajeto são destinadas aos clientes. Assim, o total de frutas que chega da fazenda $(12.040 \mathrm{~kg})$ será multiplicado pela diferença entre $100 \%$ e a soma dos níveis de refugo (25\%, por exemplo) e perda de água (2\%). Dessa forma, $73 \%$ das frutas que chegam da fazenda serão destinadas ao cliente, ou seja, $8.789 \mathrm{~kg}$.

Total de laranjas enceradas (kg): de acordo com dados fornecidos pelo produtor responsável por essa planilha, tem-se que as frutas que recebem cera correspondem à soma:

- das frutas destinadas ao cliente, ou seja, $73 \%$ (considerando-se $25 \%$ de refugo) do total de $12.040 \mathrm{~kg}$;

- de parte das frutas que perdem água por transpiração, isto é, $80 \%$ do total de $2 \%$ (resultando em $1,6 \%$ do total de $12.040 \mathrm{~kg}$ );

- de parte das laranjas que são classificadas como refugo (considerando-se o nível de $25 \%$, por exemplo), ou seja, $60 \%$ do total de $25 \%$ (resultando em $15 \%$ do total de $12.040 \mathrm{~kg}$ ). 
Assim, tem-se que a soma dessas porcentagens equivale a $89,6 \%$ (que equivale à soma de $73 \%, 1,6 \%$ e 15\%). A partir disso, multiplica-se o total de frutas vindas da fazenda $(12.040 \mathrm{~kg})$ pela porcentagem de frutas que corresponde àquelas que receberam cera $(89,6 \%)$, obtendo-se, conforme a Tabela 9, um valor correspondente a $10.788 \mathrm{~kg}$ de frutas enceradas. É importante observar que as frutas que perdem água por transpiração e as consideradas como refugo passam duas vezes pelo processo de seleção: o primeiro é realizado antes de serem postas no maquinário para beneficiamento e o segundo após terem sido passadas pelo beneficiamento e pela aplicação de cera.

Frete médio indústria (R\$/caminhão truck): tomourse como referência um valor médio do frete para um caminhão truck com capacidade para 375,8 caixas de 40,80 kg, o que corresponde a R\$210,00 para uma distância média de $120 \mathrm{~km}$ a partir do Packing-House até a indústria. Deve-se ressaltar que a carga considerada na planilha refere-se a uma carga de um caminhão truck $(12.040 \mathrm{~kg})$ vinda da fazenda de produção. No entanto, essa carga será dividida entre frutas destinadas à indústria, frutas destinadas ao cliente e frutas descartadas devido à perda de água. Dado esse aspecto, após todo o processo de beneficiamento e seleção, a carga de fruta destinada à indústria (que corresponde a uma parcela de uma carga de caminhão truck) não será equivalente a um caminhão cheio. Como se está considerando neste trabalho a carga de apenas um caminhão truck, para proporção nos cálculos, irá considerar-se o valor do frete por caixa, dividindo-se o valor do frete de um caminhão ( $\mathrm{R} \$ 210,00)$ pela sua capacidade $(375,8$ caixas-peso). Multiplicando-se esse resultado pelo número de caixas destinadas à indústria (73,8 caixas-peso), chega-se a um valor total de frete de $\mathrm{R} \$ 41,24$ (o que corresponderia à carga de 0,20 caminhão).

A receita obtida com a venda da laranja para os clientes é calculada com a multiplicação do preço da laranja ( $\mathrm{R} \$ 0,68 / \mathrm{kg}$, por exemplo) pela quantidade de fruta destinada a esse mercado $(8.789 \mathrm{~kg})$. Já a receita obtida com a venda da laranja para a indústria pode ser obtida mediante a multiplicação do preço da caixa de 40,80 kg (R\$ 8,00/caixa-peso, por exemplo) pela quantidade, em caixas, de frutas destinadas à indústria (73,80 caixas-peso). 
Calculados os volumes de laranjas destinadas à indústria e aos clientes, e tendo o valor em reais do quilo da fruta a ser vendida, obtêm-se a receita com a venda de frutas aos clientes $(\mathrm{R} \$ 5.976,52)$ e a receita adquirida por meio da venda de laranja à indústria ( $\mathrm{R} \$$ 590,40). Assim, somando-se essas duas receitas e subtraindo o valor correspondente ao frete médio da unidade de beneficiamento até a indústria ( $R$ \$ 41,24), obtém-se o valor total de receita com a venda de laranjas, para os diferentes níveis de refugo considerados. Para o nível de refugo de $25 \%$, por exemplo, a receita total corresponde a $\mathrm{R} \$ 6.525,68$.

\section{- Cálculo das Despesas Totais}

Para o cálculo das despesas, são considerados diversos fatores relacionados a cada nível de refugo. A seguir, tem-se a relação desses fatores, ilustrados com alguns valores.

Fruta (R\$/caminhão truck): no exemplo analisado, consideraram-se a laranja da variedade Pêra e o preço de $\mathrm{R} \$ 12,00$ para cada caixa de 40,80 $\mathrm{kg}$, a partir da fazenda até o Packing-House. Conforme já salientado, essa planilha refere-se à carga de um caminhão truck com $12.040 \mathrm{~kg}$ ou 295,1 caixas de 40,80 kg. Assim, multiplicando-se o preço de cada caixa de 40,80 $\mathrm{kg}$ pelo total de frutas transportadas até a unidade de beneficiamento (295,1 caixas), obtém-se o valor resultante da compra da laranja na fazenda para beneficiamento $(\mathrm{R} \$ 3.541,20)$.

Colheita (R\$/caminhão truck): se o custo referente à mão-de-obra para colheita de laranja na fazenda não estiver embutido no preço da caixa de 40,80 kg vendida ao Packing-house, deverá ser computado na planilha por meio da multiplicação do valor dessa atividade ( $\mathrm{R} \$ 1,70$ por caixa, por exemplo) pela quantidade de caixas de $40,80 \mathrm{~kg}$ destinadas à unidade de beneficiamento (295,1 caixas), obtendo-se $\mathrm{R} \$ 501,67$, referentes à carga de um caminhão truck. 
Frete Fazenda - Packing-House (R\$/caminhão truck): o valor do frete, por caminhão truck com 295,1 caixas de 40,80 kg, equivale a $\mathrm{R} \$ 120,00$, considerando-se um trajeto de $50 \mathrm{~km}$ a partir da fazenda até o Packing-House.

Despesas com uso de embalagens ( $\mathrm{R} \$ /$ caminhão truck): neste item podem ser consideradas as despesas com a embalagem sob o sistema retornável (madeira ou "plástico comprada"), com a embalagem de papelão ou com a embalagem plástica sob o sistema de aluguel. Para fins ilustrativos, considerou-se a embalagem de madeira, sob o sistema retornável, para explicar os cálculos referentes a este item. Dessa forma, se a embalagem utilizada for a caixa de madeira tipo "M" (27 kg), em que o gerenciamento de retorno é realizado pelo proprietário de um Packing-House, considera-se, por exemplo, R\$ 3,00 o preço de cada embalagem. Desse modo, o custo de utilização desse tipo de embalagem é dado pela divisão do preço de uma embalagem retornável nova em função do número máximo de viagens realizadas por ela, até o término de sua vida útil (geralmente são dez viagens). Esse resultado é dividido pela capacidade dessa embalagem $(27 \mathrm{~kg})$ e, em seguida, multiplicado pela quantidade de frutas destinadas às CEASAs e/ou CEAGESP, aos supermercados ou demais clientes (8.789 kg), obtendo-se, assim, R\$ 97,66 referentes às despesas com embalagens de madeira por caminhão truck. Se a embalagem utilizada fosse a caixa plástica comprada retornável $(27 \mathrm{~kg})$, o processo de cálculo de sua utilização seria semelhante ao realizado para a caixa de madeira tipo "M", sendo 60 o número médio de viagens realizadas por esse tipo de embalagens até o término de sua vida útil e de $\mathrm{R} \$ 8,00$ a $\mathrm{R} \$ 10,00$ o preço de uma embalagem nova.

Se a embalagem utilizada fosse a caixa plástica de $20 \mathrm{~kg}$, sob o sistema de aluguel gerenciado por redes de supermercados, iria considerar-se, por exemplo, como $\mathrm{R} \$ 1,60$ o preço do aluguel de cada embalagem (valor fornecido por produtores do setor, em abril de 2003). No entanto, a cada lote de caixas alugado, o produtor deveria alugar mais dois para que se tivesse a seguinte distribuição dos lotes das caixas: um lote ficaria na propriedade, o outro na central de embalagens e o terceiro nas filiais do supermercado (com frutas). Com isso, o valor do aluguel de embalagens seria referente a três vezes o aluguel de uma caixa, ou seja, $\mathrm{R} \$ 4,80$ ( $\mathrm{R}$ 1,60 multiplicado por três lotes). Além disso, 
para cada caixa, de capacidade de $20 \mathrm{~kg}$, consideram-se oito viagens realizadas em um mês. Assim, o custo de utilização desse tipo de embalagem seria dado pela divisão do preço de aluguel ( $\mathrm{R} \$ 4,80$, no exemplo) de uma caixa em função do número máximo de viagens realizadas no período de um mês (8 viagens, no exemplo). Esse resultado seria dividido pela capacidade (20 kg) da embalagem e, em seguida, multiplicado pela quantidade de frutas destinadas ao cliente $(8.789 \mathrm{~kg})$. Poderia obter, dessa forma, a despesa referente à embalagem utilizada, equivalente a $\mathrm{R} \$ 263,67$ da carga de um caminhão truck vindo da fazenda produtora. Cabe ressaltar que a higienização dessas embalagens ocorre na central do supermercado, e o preço por esse serviço já está incluso no aluguel. Já o preço referente ao descarregamento do caminhão cheio na central e carregamento do mesmo com embalagens vazias não está incluso no valor do aluguel, sendo considerado um valor extra, analisado no item "despesas com carregamento/descarregamento (R\$caminhão truck)".

Caso se a embalagem utilizada fosse a de papelão, este item iria referir-se aos tipos de embalagens compradas e que não se incluem na classificação das embalagens citadas anteriormente. Essas embalagens são descartáveis, conhecidas como one way, citando-se como exemplos a caixa de papelão de $18 \mathrm{~kg}$ (para mercado interno), a caixa de papelão de $8 \mathrm{~kg}$ (para mercado externo) e o saco de $20 \mathrm{~kg}$ (tipo "redinha"). Para efeitos comparativos entre embalagens tipo "caixa", considerou-se neste trabalho apenas a caixa de papelão de $18 \mathrm{~kg}$ (para mercado interno). Logo, o custo de utilização desse tipo de embalagem seria dado pela divisão do preço de uma caixa de papelão descartável, no caso R\$2,00 pela capacidade da mesma, ou seja, $18 \mathrm{~kg}$. O resultado seria multiplicado pela quantidade de frutas destinadas aos clientes diretos $(8.789 \mathrm{~kg})$, que poderiam ser supermercados ou atacadistas, exceto CEASAs e/ou CEAGESP, obtendo-se a despesa referente a $\mathrm{R} \$ 976,56$ por caminhão truck .

Despesas com embalagens retornáveis perdidas (R\$/caminhão truck): são despesas referentes às perdas de embalagens retornáveis enviadas ao cliente. Esse cálculo é feito considerando-se, em média, $10 \%$ (no caso da embalagem utilizada ser a de madeira tipo "M") do total de despesas relacionadas ao custo de utilização de 
embalagens compradas retornáveis ( $\mathrm{R} \$$ 97,66). Dessa forma, obtém-se um valor equivalente a $\mathrm{R} \$$ 9,77, referente à carga de um caminhão truck. Quando se utilizar embalagens plásticas sob o sistema de aluguel, as perdas ou extravios destas durante o retorno são considerados nulos, devido à eficiência no processo administrativo das mesmas pelo supermercado. No entanto, se alguma embalagem for perdida no percurso entre o produtor e a central, o responsável deverá ser o produtor, que pagará o preço de $\mathrm{R} \$ 8,00$ por embalagem extraviada. Se as embalagens retornáveis utilizadas corresponderem às embalagens de "plástico comprada", o cálculo das despesas com as embalagens extraviadas ou perdidas é semelhante ao realizado inicialmente para as embalagens de madeira, considerando-se neste caso o valor de $2 \%$ do total de despesas relacionadas ao custo de utilização de embalagens compradas retornáveis.

Despesas com carregamento/descarregamento ( $\mathrm{R} \$$ /caminhão truck): essas despesas somente são consideradas na utilização de embalagens plásticas alugadas. Quando o caminhão truck chega à central de embalagens de um supermercado com as frutas devidamente embaladas, é cobrada uma taxa que inclui o preço para descarregamento desse caminhão e carregamento dele com embalagens vazias, que retornarão aos produtores. Essa taxa equivale atualmente a $\mathrm{R} \$ 7,50$ por caminhão truck. Assim, esse valor será dividido por $12.000 \mathrm{~kg}$ (que é a capacidade média de um caminhão truck) e, em seguida, multiplicado pela quantidade destinada à venda de frutas para o supermercado $(8.789 \mathrm{~kg})$, obtendo-se a despesa equivalente a $\mathrm{R} \$ 5,49$. Como no exemplo a embalagem considerada foi a de madeira, esse item apresentará valor nulo na Tabela 9.

Despesas com rótulos (R \$/caminhão truck): dada a publicação e validação da Portaria 62, no caso específico da laranja, as embalagens deverão apresentar rótulos, discriminando a origem e as características do produto. Segundo alguns produtores do setor, esses rótulos representam despesas equivalentes a $\mathrm{R} \$ 0,10$ por embalagem. Assim, esse valor será dividido pela capacidade da embalagem, no caso $27 \mathrm{~kg}$, pois se está considerando o uso de embalagem de madeira, e o total multiplicado pela quantidade destinada à venda de frutas para o cliente $(8.789 \mathrm{~kg})$, obtendo-se $\mathrm{R} \$ 32,55$ equivalentes a 
uma carga de caminhão truck. Esse tipo de despesa será válido para o produtor que utilizar somente "embalagens compradas retornáveis", pois embalagens descartáveis, como as de papelão, permitem a impressão de dados referentes à rastreabilidade do produto (sendo esse valor considerado no preço da embalagem). Já as embalagens "plásticas alugadas", por possuírem um local para portar um cartão com os dados específicos do produtor e das respectivas frutas vendidas, apresentam os custos referentes àrotulagem embutidos no item "Beneficiamento (R\$/caminhão truck)".

Beneficiamento (R\$/caminhão truck): as frutas que chegam da fazenda ao Packing-House passam por um processo de beneficiamento (seleção e lavagem, por exemplo), considerando-se $\mathrm{R} \$ 0,05 / \mathrm{kg}$ como custo de beneficiamento da fruta. Neste item, os gastos referentes à aplicação de cera não estarão embutidos, sendo calculados no item "Cera (R $\$$ /caminhão truck), pois não são todas as frutas que ao chegar à unidade de beneficiamento recebem aplicação de cera. No caso da utilização da embalagem de papelão, esse custo seria maior e equivalente a $\mathrm{R} \$ 0,08 / \mathrm{kg}$, por exemplo, pois, para esse tipo de caixa, consideram-se despesas como custos de utilização de grampos e/ou cola, além da mão-de-obra extra para montagem dessas caixas. O custo de beneficiamento, referente a $\mathrm{R} \$ 0,05 / \mathrm{kg}$ de fruta, seria então multiplicado pelo total de quilos de laranjas recebidas da fazenda (12.040 $\mathrm{kg}$ considerados inicialmente), obtendo-se assim o total de despesas referentes ao beneficiamento da carga de um caminhão truck ( $\mathrm{R} \$ 602,00$ ). Pode-se também considerar como despesas referentes ao beneficiamento gastos com toda a mão-de-obra envolvida nesse processo, despesas com higienização de embalagens (de plástico e de madeira retornáveis), gastos com aplicação de fungicidas em embalagens retornáveis e, somente para as embalagens plásticas sob o sistema de aluguel, despesas com cartões de papel em que são designados dados referentes à origem das frutas e do produtor, sendo equivalentes a um rótulo para rastreabilidade do produto.

Intermediação (R\$/caminhão truck): esse processo ocorre quando terceiros responsabilizam-se por vender as frutas beneficiadas no Packing-House. Quando isso acontece, os intermediários recebem $2 \%$ do total vendido. Dessa forma, a taxa de intermediação equivale a $2 \%$ (podendo variar conforme cada produtor), e assim sendo, 
essa porcentagem é aplicada sobre a receita obtida com a venda de frutas para o cliente ( $\mathrm{R} \$ 5.976,52)$, obtendo-se dessa forma a despesa com intermediários $(\mathrm{R} \$ 119,53)$.

Cera (R\$/caminhão truck): o preço de um tambor de cera (para beneficiar $160.000 \mathrm{~kg}$ de frutas) equivale a aproximadamente $\mathrm{R} \$ 510,00$. Assim, divide-se o preço de um tambor de cera pela sua capacidade de beneficiamento equivalente $(160.000 \mathrm{~kg})$. Esse resultado é multiplicado pelo total de quilos de frutas enceradas $(10.788 \mathrm{~kg}$ ). Obtém-se, desse modo, a despesa de $\mathrm{R}$ \$ 34,39 referente à utilização de cera para a carga inicialmente considerada $(12.040 \mathrm{~kg})$.

Frete Packing-House - Cliente (R\$caminhão truck): conforme já explicado no item "Frete médio indústria $(\mathrm{R} \$)$ ", está se considerando neste trabalho a carga de apenas um caminhão truck. Assim, para proporção nos cálculos, irá considerar-se um valor de frete até o cliente equivalente a "um" caminhão truck. Assim, considerando-se uma distância entre 250 e $300 \mathrm{~km}$ para esse trajeto, o valor do frete por caminhão truck equivale a $\mathrm{R} \$ 580,00$. Logo, divide-se o valor do frete do caminhão pela sua capacidade $(12.000 \mathrm{~kg})$. Esse resultado é então multiplicado pela quantidade de frutas destinadas ao supermercado ou cliente em geral $(8.789 \mathrm{~kg})$, obtendo-se a despesa $(\mathrm{R} \$ 424,80)$ relativa ao frete da unidade de beneficiamento ao cliente (supermercado, por exemplo), o que corresponderia à carga de 0,73 caminhão. Cabe ainda ressaltar que não estão incluídos nesse item os valores equivalentes ao ICMS, seguros e pedágios incidentes sobre o frete, sendo estes fatores considerados no item "Despesas ICMS/frete + Permissão Trânsito (R\$/caminhão truck)". Entretanto, se as despesas como ICMS e seguro da carga, por exemplo, já estiverem incluídas no valor do frete, tornando-o impreciso se retiradas, deve-se considerar esse valor conjunto no item "Frete Packing-House - Cliente (R\$/caminhão truck)", e, conseqüentemente, apresentar um valor nulo no item "Despesas ICMS/frete + Permissão Trânsito (R\$/caminhão truck)". 
Despesas Diversas (R \$/caminhão truck): são despesas ocorridas durante o transporte, como por exemplo, despesas com "chapas"12, com refeições do motorista, com pedágios e também despesas com descarregamento das frutas no cliente. No exemplo, essas despesas correspondem a R \$ 60,00 por caminhão truck. Assim, divide-se esse valor pela capacidade média do caminhão (12.000 kg). O resultado obtido é então multiplicado pela quantidade de frutas destinadas ao supermercado ou outro cliente em geral $(8.789 \mathrm{~kg})$, obtendo-se $\mathrm{R} \$ 43,95$ como o total de despesas diversas para cada carga equivalente a um caminhão truck.

Despesas ICMS/frete + Permissão Trânsito (R\$/caminhão truck) $:$ a permissão $^{13}$ para transportar uma mercadoria em alguns estados corresponde, para citros, a um valor médio de $\mathrm{R} \$ 30,00$ por caminhão. Para o caso do transporte de frutas cítricas, segundo os produtores entrevistados, é cobrada a Permissão de Trânsito quando destinadas aos Estados de Mato Grosso, Paraná, Minas Gerais e São Paulo. Assim, esse valor somente será somado ao ICMS incidente sobre o frete se a mercadoria for destinada a outro estado. Já o valor do ICMS sobre o frete varia de acordo com o estado de destino. Dessa forma, segundo Brasil (2002), se os estados destinatários forem Minas Gerais, Paraná, Rio de Janeiro, Santa Catarina e São Paulo, o ICMS corresponderá a $12 \%$ do valor do frete. Se os estados de destino pertencerem às regiões Norte, Nordeste e Centro-Oeste, ou se corresponder especificamente ao Estado do Espírito Santo, o ICMS corresponderá a 7\% do valor do frete. Para melhor compreensão desse cálculo, considera-se que o destinatário localiza-se no Estado de São Paulo e, assim sendo, não se considera o valor referente à permissão para trânsito. Dessa forma, o valor do ICMS sobre o frete a partir da unidade de beneficiamento até o cliente ( $\mathrm{R} \$ 580,00)$ será de $12 \%$, proporcionando um valor de $\mathrm{R} \$ 69,60$. Logo, esse valor será então dividido pela capacidade do caminhão truck $(12.000 \mathrm{~kg}) \mathrm{e}$, em seguida, multiplicado pelo total de

\footnotetext{
12 Chapas são trabalhadores que ajudam na descarga dos caminhões. COMEÇA fraca a greve dos caminhoneiros no Estado. http://an.uol.com.br/2001/jan/30/0eco.htm(03 Nov. 2003).

13 Permissão de Trânsito: documento que acompanha mudas ou partes de vegetais destinadas à multiplicação, quando houver restrição ao livre trânsito. http://www.agricultura.gov.br/sarc/dfpv/ in_03_1984.htm(04 nov. 2003)
} 
frutas destinadas ao cliente $(8.789 \mathrm{~kg})$, resultando em $\mathrm{R} \$ 50,98$ como despesas de ICMS sobre o frete de um caminhão truck.

Despesas bancárias (R\$/caminhão truck): são despesas com emissão de boleto bancário, por exemplo, para o cliente efetuar o pagamento da carga adquirida. Assim, divide-se o valor das despesas bancárias ( $\mathrm{R} \$ 2,00$, em média) correspondentes à carga de um caminhão truck pela capacidade média do mesmo $(12.000 \mathrm{~kg})$. O resultado obtido é então multiplicado pela quantidade de frutas destinadas ao supermercado ou outro cliente em geral $(8.789 \mathrm{~kg})$, obtendo-se o total de despesas bancárias $(\mathrm{R} \$ 1,46)$ para uma carga equivalente a $12.000 \mathrm{~kg}$.

Funrural (R\$/caminhão truck): essa taxa corresponde a 2,3\% do total de receita obtida com a venda de frutas para o supermercado ou outros clientes $(8.789 \mathrm{~kg})$, obtendo-se, assim, $\mathrm{R} \$ 137,46$ por caminhão truck.

Desconto Financeiro (R\$/caminhão truck): equivale a uma taxa estabelecida pelo supermercado (somente quando este for o comprador da carga), a qual é descontada no preço de compra das frutas. Dessa forma, o supermercado, com aplicação do desconto financeiro, paga um valor menor pela aquisição da mercadoria. Os supermercados exigem essa taxa a fim de repassar seus custos logísticos e custos provenientes de promoções realizadas aos seus consumidores, para os produtores (fornecedores das frutas). Geralmente essa taxa varia entre 3\% e 15\% (dependendo se o supermercado pertence às pequenas ou grandes redes) do total de receita obtida com a venda de frutas para esse cliente. Para fins de cálculo e exemplificação, considera-se neste item o desconto financeiro de $3 \%$ (correspondente à taxa cobrada por um supermercado pertencente a uma pequena rede e que aceita frutas embaladas em caixas de madeira). Dessa forma, poderia observar-se uma despesa equivalente a R $\$ 179,30$, resultante da aplicação de uma taxa equivalente a $3 \%$ da receita do produtor obtida com a venda de frutas ao supermercado ( $\mathrm{R} \$ 5.976,52)$.

Custo de oportunidade da embalagem (R \$/caminhão truck): para melhor compreensão deste item, cabe ressaltar o conceito de custo de oportunidade. Segundo 
Ross et al. (2002), se um ativo for utilizado em um projeto, as receitas que possa gerar em empregos alternativos serão perdidas e estas deverão ser vistas como custos, então denominados de "custos de oportunidade". Assim, no caso do presente trabalho, ao realizar o projeto de compra de embalagens, o produtor renuncia a outras oportunidades de investimentos, como, por exemplo, investir na poupança a uma taxa de $0,80 \%$ ao mês, investimento alternativo considerado neste estudo. Considerou-se o período de um mês, pois, de acordo com os produtores entrevistados, esse é o intervalo médio de tempo necessário para efetuar o pagamento das embalagens adquiridas. Logo, para cada tipo de embalagem utilizada, têm-se os respectivos custos de oportunidade.

Se o produtor utilizasse a embalagem de aluguel, o custo de oportunidade seria obtido com a multiplicação da taxa de investimento na poupança, ou seja, $0,80 \%$ ao mês (dado referente a setembro de 2003) pelo valor investido na embalagem de aluguel no período equivalente. Assim, seria multiplicado $0,80 \%$ por $\mathrm{R} \$ 4,80$ ( $\mathrm{R} \$ 1,60$ multiplicado por três lotes). O valor obtido seria então dividido pelo total de frutas carregadas por essa embalagem ao longo de um mês (160 kg), ou seja, este último valor poderia ser obtido com a multiplicação da capacidade da embalagem $(20 \mathrm{~kg})$ pelo número de viagens realizadas no período de um mês (8 viagens). $\mathrm{O}$ total resultante desses cálculos seria multiplicado pelo total de frutas $(8.789 \mathrm{~kg})$ destinadas ao cliente, obtendo-se R $\$ 2,1094$ como custo de oportunidade referente à carga de um caminhão truck que veio da fazenda produtora.

Se o produtor usasse embalagens compradas retornáveis, de maneira semelhante, o custo de oportunidade seria obtido com a multiplicação da taxa de investimento na poupança, ou seja, $0,80 \%$ ao mês (dado referente a setembro de 2003) pelo valor investido na compra da embalagem retornável, preço este que deveria ser pago ao final de um mês ( $R$ \$ 3,00 se a embalagem for de madeira ou $R \$ 8,00$ se for de plástico, por exemplo). O resultado seria dividido pelo total de frutas carregadas por essa embalagem ao longo de um mês (162 kg), obtido com a multiplicação da capacidade da embalagem (27 kg, tanto para embalagens plásticas como para as de madeira) pelo número de viagens realizadas no período de um mês (6 viagens, tanto para 
embalagens plásticas como para as de madeira). Logo, o total resultante desses cálculos seria então multiplicado pelo total de frutas $(8.789 \mathrm{~kg})$ destinadas ao cliente. Como se está considerando a embalagem de madeira para ilustração dos cálculos da planilha, temse que o custo de oportunidade referente à aquisição de embalagens necessárias para transportar e embalar as laranjas destinadas ao cliente (a partir de uma carga de caminhão truck vinda da fazenda) equivale a $\mathrm{R} \$ 1,30$.

Se o produtor utilizasse embalagens descartáveis, tal como a caixa de papelão de $18 \mathrm{~kg}$ (para mercado interno), para obtenção do custo de oportunidade, seria necessário também multiplicar a taxa de investimento na poupança $(0,80 \%$ ao mês $)$ pelo valor investido na compra da embalagem descartável, preço este que deveria ser pago ao final de um mês (R\$ 2,00). Então, o resultado seria dividido pelo total de frutas carregadas por essa embalagem ao longo de um mês $(18 \mathrm{~kg})$, obtido com a multiplicação da capacidade da embalagem $(18 \mathrm{~kg}$ ) pelo número de viagens realizadas no período de um mês, que nesse caso equivale a apenas uma viagem, pois a embalagem é descartável. Dessa forma, o total obtido nesses cálculos seria multiplicado pelo total de frutas (8.789 $\mathrm{kg}$ ) destinadas ao cliente, obtendo-se o custo de oportunidade de $\mathrm{R} \$ 7,81$, referente à carga de um caminhão truck.

Perdas pelo uso da embalagem (R\$/caminhão truck): quando os clientes se localizarem a uma distância superior a $1000 \mathrm{~km}$ do Packing-House, perdas de $10 \%$ e de $2 \%$ podem ser observadas na carga de um caminhão truck, quando utilizadas as embalagens de madeira e de papelão, respectivamente ${ }^{14}$. Se tal fato ocorresse, poderia observar-se a mesma porcentagem de perdas dos frutos destinados aos clientes sobre a receita obtida com a venda das frutas. Assim, como no caso está se considerando a embalagem de madeira, seria observada uma despesa correspondente a $10 \%$ do total da receita obtida com a venda de laranja ao cliente, ou seja, $\mathrm{R} \$$ 5.976,52. Dessa forma, um gasto de $\mathrm{R} \$ 597,65$ por caminhão truck poderia ser obtido se o produtor utilizasse embalagem de madeira para entregar laranjas em mercados localizados a partir de 1.000

\footnotetext{
14 Estimativas de perdas fornecidas pelos produtores entrevistados e pelo Instituto de Pesquisas Tecnológicas (IPT), 2003.
} 
km da unidade de beneficiamento. O valor de $\mathrm{R} \$ 597,65$ somente é observado na Tabela 9 por motivos de exemplificação e de compreensão desse cálculo, uma vez que não seria necessária sua constatação pelo fato de o cliente, no exemplo considerado, se localizar a uma distância compreendida entre 200 e $300 \mathrm{~km}$ da unidade de beneficiamento, conforme esclarecido no item "Frete Packing-House - Cliente (R\$caminhãotruck)".

\section{- Cálculo do Lucro}

Lucro (ou prejuízo) sem depreciação (R \$/caminhão truck): é dado pela diferença entre a receita total e a despesa total, obtendo-se $\mathrm{R} \$ 30,02$. A receita total é dada pela soma da receita obtida por meio da venda de frutas aos clientes e a receita adquirida mediante a venda de laranja à indústria. Já a despesa total é dada pela soma de todos os fatores anteriormente mencionados.

Depreciação 8 anos (R $\$$ /caminhão truck): o lucro (ou prejuízo) obtido não leva em consideração a depreciação do maquinário de beneficiamento das frutas no Packing-House, sendo chamado de lucro bruto. Assim, considerando-se que o valor desse maquinário seja de $\mathrm{R} \$ 1.000 .000,00$ e a sua depreciação seja de 8 anos, tem-se, por ano, uma depreciação de $\mathrm{R} \$ 125.000,00$. Além disso, a capacidade desse maquinário é de beneficiar 320.000 caixas $(40,80 \mathrm{~kg}$ ) de laranja ou $13.056 .000 \mathrm{~kg}$ dessa fruta. Dessa forma, dividindo-se o valor da depreciação anual desse maquinário $(\mathrm{R} \$ 125.000,00)$ pela sua capacidade anual de beneficiamento $(13.056 .000 \mathrm{~kg})$, obtém-se o valor da depreciação por quilo de fruta que chega à unidade de beneficiamento a partir da fazenda ( $\mathrm{R}$ \$ 0,010). Logo, como os valores exemplificados da planilha considerada referem-se a uma carga de caminhão truck, multiplica-se então o valor da depreciação por quilo de fruta pela quantidade de frutas recebidas no Packing-House $(12.040 \mathrm{~kg})$, obtendo-se o valor de $\mathrm{R} \$ 115,27$, equivalente à depreciação do maqui nário (8 anos) para a carga considerada.

Lucro (ou prejuízo) líquido ( $\mathrm{R} \$$ caminhão truck): será calculado por meio da diferença entre o lucro bruto e o valor da depreciação do maquinário de beneficiamento sobre essa carga considerada, obtendo-se um prejuízo de $\mathrm{R} \$ 85,25$. 
A seguir, são realizadas algumas comparações entre os lucros obtidos nos diferentes níveis de refugo, partir da utilização de alguns indicadores.

Valor do quilo de laranja destinada ao cliente, sem depreciação ( $\mathrm{R} \$ / \mathrm{kg}$ ): inicialmente esse indicador é calculado por meio da diferença entre a despesa total $(\mathrm{R} \$$ 6.495,66) e a receita $(R \$ 549,16)$ referente às frutas vendidas para a indústria (que corresponde à diferença entre o valor de $\mathrm{R} \$ 590,40$, obtido com a venda de laranjas para a indústria e $\mathrm{R} \$ 41,24$ correspondente ao valor médio do frete até a mesma). O resultado obtido é dividido pela quantidade $(8.789 \mathrm{~kg})$ de frutas destinadas ao supermercado ou outro cliente, obtendo-se neste caso um custo de $\mathrm{R} \$ 0,68 / \mathrm{kg}$ de laranja destinada ao cliente.

Valor do quilo de laranja destinada ao cliente, com depreciação ( $\mathrm{R} \$ / \mathrm{kg}$ ): esse indicador é calculado pela diferença entre a despesa total, que corresponde a $\mathrm{R} \$$ 6.495,66, a receita $(\mathrm{R} \$ 549,16)$ referente às frutas vendidas para a indústria e a depreciação do maquinário (8 anos) sobre a carga de um caminhão truck considerada (R\$ 115,27). O resultado contabilizado é então dividido pela quantidade de $8.789 \mathrm{~kg}$ de frutas destinadas ao supermercado ou outro cliente, obtendo-se neste caso um custo de $\mathrm{R} \$ 0,69 / \mathrm{kg}$ de laranja destinada ao cliente.

Valor de venda por quilo $(\mathrm{R} \$ / \mathrm{kg})$ : corresponde ao preço do quilo de laranja vendida ao cliente $(\mathrm{R} \$ 0,68)$.

Lucro (ou prejuízo), sem depreciação (\%): corresponde ao cálculo que envolve a diferença entre o preço da laranja ( $\mathrm{R} \$ 0,68 / \mathrm{kg}$ ) vendida ao cliente e o valor obtido de laranja destinada ao cliente, sem depreciação do maquinário ( $R$ \$ 0,68/kg), dividido por este último fator. No caso considerado, obteve-se um lucro de 0,50\%.

Lucro (ou prejuízo), com depreciação (\%): corresponde ao cálculo que envolve a diferença entre o preço da laranja $(R \$ 0,68 / \mathrm{kg})$ vendida ao cliente e o valor obtido de laranja destinada ao cliente, com depreciação do maquinário ( $R$ \$ 0,69/kg), 
dividido por este último fator. Na ilustração apresentada, observa-se um prejuízo de $1,41 \%$.

Dessa forma, estabelecendo-se comparações com as porcentagens obtidas de lucro com depreciação, pôde-se observar para que nível máximo de refugo é considerada viável a venda de laranjas. Além disso, sob as mesmas condições de receitas e despesas obtidas com os processos de compra, beneficiamento e venda de uma carga de laranja de $12.040 \mathrm{~kg}$ (vinda da fazenda produtora), pôde-se analisar e estabelecer qual das embalagens é mais viável economicamente, sob o ponto de vista de utilização, considerando-se diferentes tipos e sistemas de embalagens, com os custos envolvidos com cada um desses fatores.

\subsection{Método proposto e instrumental metodológico}

Alguns dos principais estudos e pesquisas realizados para definição do custo de utilização de uma embalagem específica puderam ser observados na seção anterior. Dos trabalhos citados consideraram-se como mais relevantes a planilha formulada por Gutierrez (2001) e a desenvolvida pelas Fazendas Reunidas Raio de Sol, op. cit., p.50.

Para chegar à definição de uma planilha, completa e de fácil manipulação, e que também fosse capaz de demonstrar qual dos três principais tipos de embalagem é mais viável sob o ponto de vista econômico para casos específicos, foram realizadas entrevistas com três produtores representativos do setor, durante março a outubro de 2003.

A partir da resposta obtida nessas entrevistas, adotourse então para a avaliação e análise dos objetivos deste trabalho, a planilha Fazendas Reunidas Raio de Sol, op. cit., p.50. Tal planilha, cuja estrutura se encontra reproduzida na Tabela 9, foi então considerada como instrumental metodológico para a realização deste trabalho, considerando o total de receitas e despesas de uma carga de laranjas referente a um caminhão truck, a partir da fazenda até a unidade de beneficiamento, e desta até os seus respectivos clientes. A partir desses dados, foi realizada uma análise por meio do valor 
referente ao lucro (considerando-se a depreciação do maquinário de beneficiamento das frutas) obtido com a utilização de cada tipo de embalagem para laranja para cada produtor considerado, podendo-se então escolher entre elas a mais viável economicamente. Para alimentar os dados pertinentes a essa planilha, foram contatados os mesmos produtores representativos de laranja para mesa, entrevistados inicialmente para a definição da metodologia.

Cada um dos produtores entrevistados constitui um estudo de caso sendo, portanto, essa pesquisa caracterizada como um estudo de multicasos. Para Triviños (1992), esse tipo de método científico permite ao pesquisador estudar dois ou mais casos sem a preocupação de comparação dos resultados obtidos em cada um deles. Esses estudos visam analisar um objeto de estudo, de maneira singular, mesmo que, posteriormente, tenham sido observadas semelhanças com outros casos, retratando a realidade de forma completa e profunda.

Yin (2001) relata que o passo inicial para organizar um estudo de multicasos é a definição da teoria ou a caracterização do problema. Depois, parte-se para a apresentação dos casos selecionados e para definições dos indicadores de análise. Estes são de grande importância para o processo de coleta de dados e o desenvolvimento da pesquisa, em que cada caso consiste de um estudo completo, com seus respectivos eventos relevantes e conclusões, apresentando, em determinadas situações, as causas pelas quais alguns fatos ocorreram e outros, não.

Dessa forma, este estudo visa detectar, por intermédio do uso da planilha Fazendas Reunidas Raio de Sol, op. cit., p.50, qual embalagem é mais viável economicamente sob o ponto de vista de utilização, em cada um dos casos (produtores entrevistados), dadas as respectivas condições específicas. Tal abordagem proporcionou, mediante um enfoque explicativo e analítico, o conhecimento de algumas características dos fenômenos relacionados aos processos organizacionais de cada produtor, estabelecendo-se assim o evento ideal (tipo de embalagem) para cada caso. 


\subsection{Especificação dos dados}

A validação da metodologia deste estudo ocorreu com a realização de três entrevistas coma produtores representativos do setor de citros no Estado de São Paulo. Por questões particulares e exigências de cada produtor, os entrevistados serão referidos por:

- $\quad$ entrevistado 1 ;

- $\quad$ entrevistado 2;

- entrevistado 3.

Após a definição da planilha Fazendas Reunidas Raio de Sol, op. cit., p.50 como instrumental metodológico dessa pesquisa, os três entrevistados foram novamente contatados, pessoalmente, para aferições de valores reais e relativos a cada propriedade adotados na planilha de referência, tornando-a representativa e permitindo assim caracterizar os estudos de casos específicos.

$\mathrm{Na}$ primeira vez em que se realizaram as visitas aos três produtores, documentou-se cada entrevista, tendo sido coletadas as informações das principais características de cada propriedade em questão, a serem descritas no próximo capítulo. Já na segunda vez em que se realizaram as visitas aos mesmos entrevistados, aferiram-se valores específicos de cada propriedade na planilha considerada, o que permitiu a análise da melhor alternativa para cada entrevistado e verificar se a embalagem mais viável para cada um coincidiria com a inicialmente considerada. Deve-se reforçar que este estudo não visa realizar uma análise estatística dos casos em questão (considerando-se dados por amostragem), e sim uma análise descritiva de três casos específicos, no contexto de multicasos.

Os tipos de embalagens considerados são:

- Caixas de madeira tipo "M", com capacidade para 27 kg; 
- Caixas plásticas, com capacidade para 20 e 27 kg;

- $\quad$ Caixas de papelão, com capacidade para $18 \mathrm{~kg}$.

Cada embalagem possui vantagens e desvantagens de uso, sendo relativas à cada estrutura ou ao produtor entrevistado. Para estabelecer a viabilidade de utilização de cada embalagem, é necessário conhecer também o sistema vigente, em cada estudo de caso. Assim, os sistemas relacionados ao uso das embalagens consideradas são:

- Descartável ou conhecido como one way;

- Retornável ou reutilizável.

Neste trabalho, dados os tipos de embalagens e casos estudados, tem-se que a embalagem de papelão é descartável, não retornando ao processo direto de uso de caixas, sendo, na maioria das vezes, reciclável. É muito utilizada para destinação de frutas a mercados distantes, diretamente ao cliente, sem passar por CEASAs e raramente empregada no mercado interno para comercialização em mercados próximos (somente sob exigência do cliente).

A embalagem de madeira tipo "M" é retornável, tanto em percursos diretos até o varejo, a partir da fazenda produtora, como em percursos indiretos, em que os intermediários são as CEASAs ou a CEAGESP. Cabe ressaltar que o número de viagens de retorno dilui o preço pago pela embalagem, tornando seu uso atrativo ao produtor. No entanto, deve-se considerar uma perda de aproximadamente $10 \%$ de embalagens de madeira vazias retornadas.

Já as caixas plásticas, dentro do sistema reutilizável, podem ser caracterizadas como embalagens compradas ou de aluguel. Se pertencerem ao sistema "reutilizável comprada", essas embalagens são administradas pelo próprio produtor ou algum responsável designado por ele, havendo um nível quase nulo de perdas e extravios de embalagens retornadas. $\mathrm{O}$ fato de as caixas plásticas compradas apresentarem um preço de aquisição elevado faz que os produtores comercializem as 
frutas diretamente com o varejo, evitando os intermediários CEASAs e CEAGESP, que não possuem um sistema logístico adequado, o que pode vir a acarretar um grande número de embalagens extraviadas.

Se as caixas plásticas pertencerem ao sistema "reutilizável alugada", essas embalagens serão administradas por grandes supermercados (Pão-de-Açúcar e Carrefour, por exemplo), os quais exigem que seus clientes utilizem caixas plásticas padronizadas de $20 \mathrm{~kg}$ e, para isso, efetuem um pagamento de aluguel pela utilização das mesmas.

Além dos fatores mencionados, de grande importância para a análise da viabilidade de embalagem para cada entrevistado, serão considerados três cenários para facilitar as comparações dos diferentes tipos de embalagens dentro de cada estudo de caso. Assim, por meio da Tabela 10, pode-se obter melhor compreensão de cada cenário considerado nesta pesquisa. 
Tabela 10. Especificações de cada cenário considerado, 2003.

\begin{tabular}{cll}
\hline Cenários & \multicolumn{1}{c}{ Mercado a ser atendido } & \multicolumn{1}{c}{ Embalagens possíveis } \\
\hline 1 & Supermercados de grandes redes & De plástico sob sistema aluguel \\
1 & Atacados, CEASAs ou CEAGESP & De madeira "M" \\
1 & Atacados, CEASAs ou CEAGESP & De papelão \\
1 & Atacados, CEASAs ou CEAGESP & De "plástico comprada" \\
2 & Supermercados de pequenas redes & De plástico sob sistema aluguel \\
2 & Atacados, CEASAs ou CEAGESP & De madeira "M" \\
2 & Atacados, CEASAs ou CEAGESP & De papelão \\
2 & Atacados, CEASAs ou CEAGESP & De "plástico comprada" \\
3 & Supermercados de pequenas redes & De plástico sob sistema aluguel \\
3 & Supermercados de pequenas redes & De madeira "M" \\
3 & Supermercados de pequenas redes & De papelão \\
3 & Supermercados de pequenas redes & De "plástico comprada"
\end{tabular}

Fonte: dados de pesquisa.

A partir da ilustração da Tabela 10, tem-se:

Cenário 1: considera-se a utilização da embalagem de plástico sob o sistema de aluguel, quando o cliente é um supermercado pertencente a uma grande rede (taxa de desconto financeiro equivalente a $15 \%$ e o valor do aluguel da embalagem é dado por R\$ 4,50 por embalagem). Além disso, consideram-se as utilizações das embalagens de papelão, de "plástico comprada" e de madeira "M", quando o cliente corresponde aos atacadistas, às CEASAs ou à CEAGESP (logo, a taxa de desconto financeiro nestes casos é nula).

Cenário 2 considera-se o uso da embalagem de plástico sob o sistema de aluguel, quando o cliente é um supermercado pertencente a uma pequena rede (taxa de 
desconto financeiro equivalente a 3,5\% e o valor do aluguel da embalagem é dado por $\mathrm{R} \$ 2,10$ por embalagem). Consideram-se então as utilizações das embalagens de papelão, de "plástico comprada" e de madeira "M", quando o cliente corresponde aos atacadistas, às CEASAs ou à CEAGESP (logo, a taxa de desconto financeiro nestes casos é nula).

Cenário 3: considera-se a utilização de todos os tipos de embalagens somente para clientes como supermercados pertencentes às pequenas redes. Neste caso, considera-se a taxa de desconto financeiro de 3,5\% como despesa para a utilização de todas as embalagens, além da embalagem de plástico sob sistema de aluguel.

A partir do conhecimento sobre os diferentes tipos de embalagens e respectivos sistemas, considerados neste estudo de multicasos, composto por casos específicos de três produtores entrevistados, pretende-se esclarecer qual a embalagem mais viável economicamente para cada um dos casos estudados, em cada cenário considerado.

\subsection{Considerações finais}

No próximo capítulo, são descritas as principais características dos três entrevistados e comentados os resultados obtidos a partir da planilha Fazendas Reunidas Raio de Sol, op. cit., p.50, conforme as especificações dos cenários considerados. 


\section{RESULTADOS}

A partir das entrevistas conduzidas para escolha da planilha mais adequada para os fins deste trabalho, pôde-se também observar os motivos pelos quais alguns produtores optaram pela utilização de cada tipo de embalagem, as vantagens e desvantagens de cada uma delas e os principais motivos pelos quais não mudariam de opção. Assim, durante a primeira visita realizada aos três produtores entrevistados, obtiveram-se informações para descrever o processo de utilização das embalagens para laranja de mesa. A partir disso, foram observados os principais fatores em comum entre eles e também a descrição de diferentes cenários para uso de iguais tipos de embalagens. A seguir, tem-se a descrição das três entrevistas realizadas na primeira visita, e, na sequiência, como resultado da segunda visita, tem-se a avaliação dos resultados obtidos a partir da aferição dos valores de cada produtor na planilha Fazendas Reunidas Raio de Sol, op. cit., p.50, para cada cenário considerado.

\subsection{Caracterização do tipo de embalagem para laranja de mesa e do seu processo de utilização sob a ótica do produtor entrevistado " 1 "}

O produtor entrevistado possui uma área de $8.800 \mathrm{~m}^{2}$, sendo $4.000 \mathrm{~m}^{2}$ cobertos e equivalentes à unidade de beneficiamento. São comercializados laranjas, tangerinas e limões de diversas variedades, sendo Murcote, Lima e Baía variedades consideradas nobres e de mesa.

Das frutas comercializadas, $30 \%$ são produzidos pelo entrevistado e os outros $70 \%$ são comprados de terceiros. Somente nos meses de janeiro a março, período de entressafra, comercializam-se somente as frutas produzidas no próprio PackingHouse, sem a necessidade de compra de frutas de outros produtores. 
As laranjas são colhidas em sacolas e em seguida colocadas a granel em caminhões truck ou carretas. Já as frutas de mesa são transportadas (da fazenda para a unidade de beneficiamento) em caixas plásticas de $27 \mathrm{~kg}$, em caminhões truck (450 caixas) ou carretas (780 caixas) do tipo "baú lonado"15.

A frota de caminhões que realiza o transporte da unidade produtora até o Packing-House, e deste para o ponto-de-venda, em sua maioria, é terceirizada, sendo a outra parte pertencente ao entrevistado. O valor do frete do caminhão truck, por exemplo, da fazenda para o Packing-House é de aproximadamente R $\$ 210,00$, sendo $\mathrm{R} \$$ 0,70 por caixa-peso $(40,8 \mathrm{~kg})$ para uma faixa de distância de cerca de $150 \mathrm{~km}$. Já o frete do caminhão truck a partir da unidade de beneficiamento até às CEASAs, também para uma faixa de distância de $150 \mathrm{~km}$, aproxima-se de $\mathrm{R} \$ 300,00$. Esse frete inclui a viagem de retorno, o que pode implicar que o caminhão não retorne vazio a partir da CEAGESP ou das CEASAs até a unidade de beneficiamento.

O caminhão truck geralmente retorna da CEAGESP ou da CEASA para a unidade de beneficiamento com 1.000 caixas vazias, enquanto o do tipo lonado volta com 700 unidades. Para o caso de uma carreta, esta retorna com 1.300 caixas vazias.

Ao chegar ao Packing-House, as frutas são depositadas em rampas de cimento para então serem destinadas a silos de armazenamento. Já as frutas nobres, como chegam em caixas, são colocadas na "área de caixaria", à espera do beneficiamento.

Assim, toda a fruta que chega à propriedade desse entrevistado passará pelo processo de escolha e beneficiamento, realizado por um maquinário de fabricação espanhola, o qual beneficia quinze toneladas de fruta por hora.

$\mathrm{Na}$ área de embalamento, circulam entre 12 e 15 pessoas responsáveis por esse processo. Em alguns casos raros, utiliza-se embalagem de papelão para comercialização de frutas nobres, como Lima e Murcote, destinadas ao mercado interno.

\footnotetext{
15 Baú lonado: tipo de carroceria para veículos leves, semipesados e semi-reboques de 1 , 2 e 3 eixos. Construída em estrutura de aço, sendo o revestimento lateral e do teto de lona especial de PVC ativado e laqueado, com medidas e detalhes de acabamento específico conforme marca/modelo. PRODUTOS, baú lonado. http://www.rodovia.ind.br/bau_lonado.htm (04 nov. 2003)
} 
Assim, a embalagem utilizada por esse entrevistado, o qual atende somente ao mercado interno, é a de madeira tipo "M", cuja capacidade equivale a $27 \mathrm{~kg}$. Alega não exportar por considerar o mercado internacional muito exigente, não aceitando, por exemplo, frutas com pintas pretas. Logo, atende ao mercado interno como as CEASAs e CEAGESP (maioria dos casos) e clientes diretos, como alguns supermercados (não sendo estes pertencentes às grandes redes). Na safra de 2002, esse produtor enviou à CEAGESP cerca de 2.100 caixas de madeira com laranjas por semana (8.400 caixas por mês).

Cada caminhão carregado no Packing-House passa por uma rígida conferência, no intuito de verificar se a quantidade de caixas embaladas para encher um caminhão é de fato igual à quantidade observada após o carregamento. Outra conferência é realizada na CEAGESP, assim que o caminhão chega com as frutas para a venda. Além disso, ao retornar à propriedade, o caminhão traz caixas vazias, devendo esse número coincidir com o de embalagens cheias transportadas inicialmente. É feita então uma terceira conferência do número de embalagens vazias que retornam da CEAGESP. Embora haja um processo rígido de controle de caixas por parte desse produtor, ele estima um nível de $10 \%$ de perdas dessas embalagens na CEAGESP.

As embalagens vazias retornadas são separadas, sendo que as consideradas em boas condições são destinadas à pulverização contra fungos, e as demais, consideradas em péssimas condições ou quebradas, são destinadas ao "setor de reparos", existente no próprio Packing-House, e que ocupa uma área de $300 \mathrm{~m}^{2}$.

Teoricamente, cada caixa de laranja seria vendida por aproximadamente $\mathrm{R} \$$ 15,00 na CEAGESP. Mas a esse valor é agregado $\mathrm{R} \$ 1,00$ equivalente ao custo de administração de cada caixa, além de mais $\mathrm{R}$ \$ 1,00 correspondente ao valor de perda de cada caixa, totalizando para a venda $\mathrm{R} \$ 17,00$. Segundo o entrevistado, dessa forma ele consegue repassar para o cliente os custos de administração e de perda de cada caixa, mostrando-se satisfeito por estar realizando todo esse processo há três anos. 
$\mathrm{O}$ fato de o produtor agregar um acréscimo de $\mathrm{R} \$ 1,00$ ao valor de venda de cada caixa cheia implica recuperar cada caixa perdida, por meio da compra de uma caixa maloqueira ${ }^{16}$, cujo valor é de $\mathrm{R} \$ 1,00$ aproximadamente.

Conforme informações obtidas pelo produtor, atualmente uma caixa de madeira nova, com capacidade para $27 \mathrm{~kg}$, custa entre $\mathrm{R} \$ 2,50$ e $\mathrm{R} \$ 3,00$. De acordo com esse entrevistado, para pagar o valor de cada caixa, cada unidade deveria retornar até dez vezes; porém, o máximo que ele atingiu com retorno dessas caixas foi de seis viagens. Já as caixas de madeira consideradas descartáveis custam entre $R$ \$ 1,50 e R\$ 2,00 .

As principais despesas da unidade de beneficiamento em questão correspondem a salários, encargos, manutenção de maquinários, luz, telefone e caixaria. As embalagens de madeira utilizadas não são paletizáveis, pois a CEAGESP ou a CEASA não possuem estrutura adequada (com empilhadeiras) para receber cargas unitizadas.

Atualmente o produtor encontra-se satisfeito por utilizar a caixa de madeira tipo "M" para laranja, embora não possua dados que comprovem qual tipo de embalagem seria considerado ideal e menos oneroso. Entretanto, mesmo o custo de perda das caixas sendo repassado para o cliente, a administração dessas caixas costuma representar um cansativo trabalho de retorno. Tal fato promove o desejo de utilizar outros tipos de embalagens, como as caixas plásticas alugadas, usadas por grandes redes supermercadistas (Pão-de-Açúcar e Carrefour, por exemplo), além das embalagens de papelão.

O grande receio de utilizar a caixa de papelão para a laranja refere-se ao custo operacional envolvido no processo. Se, por exemplo, for adotada a embalagem de papelão e seu concorrente usar a de madeira, teme-se que o concorrente consiga vender sua laranja por um preço unitário menor (devido a um menor custo agregado a esse tipo

\footnotetext{
${ }^{16}$ Caixas maloqueiras são caixas roubadas e revendidas (às vezes ao próprio dono) dentro das CEAGESP e/ou CEASAs por determinados grupos ou quadrilhas, assim denominados. (CEAGESP. Centro de Qualidade em Horticultura - CQH, São Paulo). Comunicação pessoal, 2002.
} 
de embalagem), fazendo que o primeiro tenha que baixar o seu preço, tornando-o equivalente ao da concorrência, mas proporcionando-lhe prejuízos.

\subsection{Caracterização do tipo de embalagem para laranja de mesa e do seu processo de utilização sob a ótica do produtor entrevistado “2”}

O produtor entrevistado é proprietário de uma área coberta equivalente a $4.600 \mathrm{~m}^{2}$, sendo $1.000 \mathrm{~m}^{2}$ destinados à área de reparo das embalagens de madeira $\mathrm{e}$ armazenamento de todos os tipos de embalagens.

São produzidas e comercializadas laranjas do tipo Lima e Baía (a partir de fevereiro) e Poncã (a partir de março). O pico de comercialização ocorre entre julho e dezembro. A partir de julho, inicia-se também a exportação da variedade Murcote.

Das frutas comercializadas, $30 \%$ equivalem àquelas produzidas pelo próprio proprietário do Packing-House e 70\% são adquiridas de outros produtores. As frutas chegam à unidade de beneficiamento em caixas plásticas de $27 \mathrm{~kg}$. Essas frutas passam por processos de seleção, beneficiamento, desverdecimento ${ }^{17}$ (em câmaras frias) e embalamento.

As frutas são embaladas em caixas de madeira (tipo "M", de $27 \mathrm{~kg}$, ou descartáveis, de $21 \mathrm{~kg}$ ), de plástico (de $27 \mathrm{~kg}$ ) e de papelão (tanto para exportação, com capacidade para $8 \mathrm{~kg}$, quanto para mercado interno, com capacidade para $18 \mathrm{~kg}$ ).

São necessárias 12 pessoas para embalar 400 caixas em uma hora. Na época de pico de comercialização, são necessárias vinte embaladeiras. $\mathrm{O}$ entrevistado não tem despesas com as embalagens, pois estas são de propriedade do cliente, sendo este o único responsável pelo custo de administração e extravio das mesmas.

Assim, o custo das embalagens é repassado ao cliente, que paga a este produtor somente pela fruta e pelo seu beneficiamento. As frutas são vendidas diretamente para atacadistas; no entanto, há vendas também para a CEAGESP e para as

\footnotetext{
${ }^{17}$ A técnica do desverdecimento consiste na exposição das frutas ao etileno ou na aplicação de geradores de etileno. Uma vez executados em condições adequadas, esses tratamentos aceleram a redução na coloração verde da casca e promovem o aparecimento das colorações típicas das variedades. KLUGE, R.A. Desverdecimento de citrus. http://www .ciagri.usp.br/ rakluge/desverd.html (04 nov. 2003)
} 
CEASAs. Entretanto, esse produtor não possui filiais nesses locais (como um box na CEAGESP, por exemplo), vendendo as laranjas com a própria marca e também para outros agregarem suas próprias marcas.

A única embalagem que é comprada por esse proprietário é a de papelão; porém, esse custo será agregado ao preço final de venda da caixa cheia juntamente com as despesas de mão-de-obra para montagem e grampos. Essas embalagens são utilizadas para atender ao mercado do Nordeste, que recebe anualmente 300 mil caixas de papelão com laranja dos tipos Poncã, Lima, Baía e Murcote. Já aos demais mercados, como o do Estado de São Paulo, são destinadas 600 mil embalagens com fruta, entre caixas plásticas e de madeira. A compra das caixas de papelão é feita semanalmente, conforme a comercialização das frutas.

Raramente essa unidade de beneficiamento apresenta estoques de embalagens de papelão e, segundo o entrevistado, isso somente ocorreu após um cliente ter optado pela embalagem de madeira em vez das caixas de papelão, depois de já efetuada a compra destas, requerendo assim sua estocagem. $\mathrm{O}$ estoque de embalagens de papelão existente não apresenta perdas, pois as condições do ambiente são adequadas e todo material é paletizado.

Para a aquisição das embalagens de papelão, o proprietário realiza uma pesquisa de mercado, analisando o preço (em média $\mathrm{R} \$ 1,70$ a unidade) e a gramatura do material, que deverá ser bastante resistente, pois será destinado a mercados distantes, como os do Nordeste.

A partir do pico de comercialização (geralmente o mês de junho), a Poncã e Murcote são destinadas em grande quantidade para o Nordeste, com um fluxo de um caminhão truck (capacidade máxima para 750 caixas de papelão cheias) por dia. $\mathrm{O}$ frete, tanto o de ida como o de volta, é pago pelo cliente.

Dificilmente as embalagens de papelão promovem perdas nas frutas (por amassamento, por exemplo). Tal fato poderá ocorrer se a distância até o cliente for muito longa, como é o caso de clientes no Nordeste. Assim, as perdas aceitáveis para 
este mercado equivalem entre $2 \%$ e $3 \%$ por caminhão, embora raramente ocorram devido àadequada gramatura do papelão.

Após o beneficiamento, o carregamento das caixas (de plástico, de madeira e de papelão) no caminhão é manual, não se utilizando empilhadeiras, pois a maioria das embalagens não apresenta medidas paletizáveis. Dessa forma, são necessárias três ou quatro pessoas para carregar um caminhão truck (750 caixas de papelão) por uma hora.

O produtor aconselha o uso da embalagem de papelão para longas distâncias, pois a mesma permite o carregamento de uma maior quantidade de fruta, pelo fato desta embalagem vazia pesar menos que a de outro material (madeira, por exemplo). Assim, quanto maior a distância a ser percorrida, maior será o frete, e, portanto, nessas condições, é mais vantajoso transportar maior quantidade de fruta.

No entanto, segundo o entrevistado, existem fortes restrições a utilizar embalagens de papelão para laranja. Considerando-se dois concorrentes, um que utilize caixa de madeira $(27 \mathrm{~kg})$ e outro, caixa de papelão $(18 \mathrm{~kg})$ e analisando-se o preço dessas caixas cheias, tem-se que a de madeira custa até $\mathrm{R} \$ 20,00$ e a de papelão, aproximadamente $\mathrm{R} \$ 15,00$. Dividindo-se o preço de cada caixa pela sua respectiva capacidade, obtém-se o valor por quilo. Assim, no caso do concorrente que utiliza a caixa de madeira, o custo da fruta será de $\mathrm{R} \$ 0,75 / \mathrm{kg}$. Já o concorrente que usar a de papelão terá o custo de $\mathrm{R} \$ 0,85$ por quilo de fruta. Dessa forma, não é vantajoso, sob o ponto de vista do consumidor, adquirir laranjas em caixas de papelão, pois ele estaria comprando cada quilo de fruta por $\mathrm{R} \$ 0,10$ a mais que se estivesse comprando em embalagem de madeira. Cabe ressaltar que essa diferença pode tornar-se mais acentuada quando se considera uma compra em larga escala.

Assim, dos três tipos de embalagens utilizados por esse produtor, a de papelão é sem dúvida a mais prática e higiênica, porém o maior problema é agregar o custo dessa embalagem ao da mercadoria. Já as caixas plásticas e de madeira apresentam maiores níveis de perdas por embalamento, custo com administração, despesas relacionadas às embalagens extraviadas e quebradas, custos de limpeza ou desinfecção e frete de retorno. Entretanto, a despesa com essas embalagens pode ser amortizada com o 
número de viagens de retorno realizadas (por exemplo, seis viagens em média, no caso da embalagem de madeira). Para esse produtor entrevistado, é indiferente utilizar qualquer um desses tipos, pois as embalagens que chegam até sua propriedade são fornecidas pelos seus clientes, cabendo ao produtor apenas a cobrança pelo valor da fruta e pelo preenchimento das embalagens. Assim, exceto no caso das embalagens de papelão, são seus clientes os responsáveis pelos custos de administração e perdas das embalagens.

\subsection{Caracterização do tipo de embalagem para laranja de mesa e do seu processo de utilização sob a ótica do produtor entrevistado “3”}

Esse entrevistado não forneceu dados específicos sobre o tamanho de seu Packing-House e outras particularidades citadas nas demais entrevistas. No entanto, salientou com grande nível de detalhamento as diferenças entre as embalagens para laranja de mesa, as vantagens e desvantagens de cada tipo de embalagem, destacando a razão da preferência para cada uma delas.

Todas as variedades comercializadas por esse produtor são variedades consideradas para mesa. Assim, têm-se como exemplo as Tangerinas, laranjas do tipo Murcote, Poncã e Cravo. Além dessas variedades, têm-se frutas consideradas de meiaestação, como a Pêra Rio, e as variedades tardias, como a Natal e a Valência.

As frutas vêm do campo em caminhões truck (quatorze toneladas ou 580 caixas), chegando ao Packing-House em caixas plásticas de $23 \mathrm{~kg}$ (sendo $2 \mathrm{~kg}$ equivalentes ao peso da caixa vazia). Considera-se, para cada caminhão, o descarte de $2 \%$ das frutas, devido à perda de água por transpiração durante o trajeto do campo à unidade de beneficiamento. Ao chegar ao Packing-House, essas frutas passam por um processo de seleção e beneficiamento. Além disso, cerca de $15 \%$ das frutas que vão para o beneficiamento (já descartados os $2 \%$ de perda) são destinadas à indústria, pois não apresentam características (cor, aspecto e tamanho, por exemplo) para serem classificadas como do tipo mesa. Excluindo-se os $2 \%$ e os $15 \%$ referentes às perdas das frutas, as demais são destinadas ao beneficiamento e vendidas, na grande maioria, para grandes redes de supermercado e atacadistas (Pão-de-Açúcar, por exemplo). 
O entrevistado adota o sistema de aluguel de embalagens plásticas para supermercados. O aluguel referente a cada caixa plástica de $20 \mathrm{~kg}$ é de aproximadamente $\mathrm{R} \$ 1,50$ e além disso, é estabelecido um contrato de venda da mercadoria para o supermercado por um determinado período de tempo. Dessa forma, independentemente do número de caixas por lote, o produtor deverá alugar três lotes de embalagens, sendo que um deles fica no Packing-House, outro em circulação e o último lote fica na central de embalagens do supermercado, disponível para retorno quando o caminhão chega com um lote de caixas cheias. A central de embalagens do supermercado é responsável pelo processo de higienização das embalagens e o custo dessa atividade está embutido no valor do aluguel. Em casos de perda de embalagem, quando o lote não estiver sob a administração da central, a responsabilidade é do produtor, que paga, para cada caixa perdida, o equivalente ao preço de uma embalagem nova, ou seja, $\mathrm{R} \$ 5,80$.

Raramente esse produtor vende frutas para as CEASAs e/ou CEAGESP. Isso somente ocorre quando o cliente fornece a embalagem, que por sua vez, é a de madeira tipo "M". Assim, as frutas são vendidas sem agregação do preço e da administração da embalagem, sendo o frete da unidade de beneficiamento às CEASAs ou CEAGESP pago pelo cliente.

Esse produtor utiliza também outros tipos de embalagens, como sacos de 20 $\mathrm{kg}$ e embalagens de papelão $(8 \mathrm{~kg})$ para exportação. A grande maioria de seus clientes é composta por supermercados e atacadistas.

Conforme observado anteriormente, o produtor entrevistado utiliza, para o mercado interno, embalagens plásticas por meio do sistema de aluguel. Prefere usar caixas plásticas sob esse sistema, pois as embalagens plásticas compradas, sob o mesmo sistema das caixas de madeira, envolvem uma preocupação, por parte do produtor, de administrar e higienizar as embalagens, ao passo que sob o sistema de aluguel, esses fatores são de responsabilidade da central de embalagens dos supermercados que as alugam, embora esses custos estejam embutidos no preço de aluguel. 
A caixa de papelão seria a ideal, dadas as condições de higiene e qualidade de impressão apresentadas por ela. Entretanto, comparando-se esse tipo de embalagem com a de madeira tipo " $\mathrm{M}$ ", tem-se que a de madeira custa em média $\mathrm{R} \$ 2,50$, com duração média de seis viagens de retorno, e a de papelão custa em média $R \$ 1,80$ por viagem, uma vez que é descartável. Logo, a de madeira custaria aproximadamente $\mathrm{R} \$$ 0,41 por viagem e a de papelão custaria $R \$ 1,80$ por viagem, ou seja, a de madeira custaria nove vezes menos que a da de papelão por viagem. Sob esse ponto de vista, a embalagem de madeira seria mais viável.

Comparando-se a embalagem plástica comprada $(27 \mathrm{~kg})$ com a de madeira tipo "M" (27 kg), tem-se que a de plástico seria mais viável, pois esta embalagem dura em média um ano, sendo cinco viagens por mês ou 60 viagens por ano. Já a embalagem de madeira possui duração média de seis viagens. Assim, sendo o preço da embalagem de plástico $\mathrm{R} \$ 5,80$, tem-se por viagem um preço de aproximadamente $\mathrm{R} \$ 0,01$. No caso da embalagem de madeira, conforme já observado, tem-se um preço de $\mathrm{R} \$ 0,41$ por viagem. Além disso, a embalagem de madeira possui um material poroso que permite o acúmulo de fungos, que provocam doenças, requerendo a aplicação de fungicida, que pode equivaler a $10 \%$ do preço da embalagem.

Existe também uma questão cultural muito forte que permite a preferência pela embalagem de madeira. Embora a caixa plástica apresente maior facilidade de manuseio e preenchimento com frutas, quando cheia, ela não apresenta a disposição de "trançado" das laranjas. Já a embalagem de madeira, por assumir diferentes dimensões e estrutura, permite que as frutas sejam arrumadas de maneira muito requisitada (e também apreciada) por seus compradores: a trançada. Neste mercado, a arrumação das frutas na embalagem de madeira é considerada uma arte. Assim, devido a essas questões culturais, muitos clientes desse produtor entrevistado deixaram de adquirir suas frutas por não serem vendidas em caixas de madeira.

Esse produtor acredita na evolução do sistema de embalagens para frutas. Além disso, tem observado que o papelão é a grande tendência em material para embalagens, embora seja considerado oneroso para frutas cítricas (que possuem baixo 
valor agregado). Assim, devido às diferenças e vantagens apresentadas, além da alta durabilidade, esse produtor optou pela embalagem de plástico, especificamente sob o sistema de aluguel, pois ele acredita repassar a preocupação da administração das caixas para as centrais de embalagens de seus clientes.

\subsection{Viabilidade econômica dos diferentes tipos de embalagem}

Para análise da viabilidade econômica dos diferentes tipos de embalagens a partir da planilha desenvolvida Fazendas Reunidas Raio de Sol, op. cit., p.50, considerou-se a mesma quantidade de frutas comercializadas, ou seja, o equivalente a uma carga de caminhão truck (12.040 kg de laranja) vinda da fazenda produtora à unidade de beneficiamento e desta para os clientes (supermercados ou atacadistas ou CEASAs).

As embalagens consideradas foram embalagens plásticas, sendo as alugadas com capacidade para $20 \mathrm{~kg}$ e as compradas e retornáveis com capacidade para $27 \mathrm{~kg}$; embalagens de madeira tipo "M" compradas e retornáveis com capacidade para $27 \mathrm{~kg}$; e embalagens descartáveis de papelão com capacidade para $18 \mathrm{~kg}$. Esse estudo de multicasos apresenta três casos distintos de produtores que utilizam embalagens diferentes. No entanto, as comparações de embalagens serão feitas dentro de cada estudo de caso, constituindo três casos singulares, não se comparando os resultados entre os produtores entrevistados. Assim, tem-se na seqüência a aferição dos dados específicos de cada produtor entrevistado na planilha adotada e, para cada um deles, foram conduzidas simulações, a partir dos mesmos dados, em cada cenário estabelecido, porém utilizando-se de embalagens diferentes das já utilizadas por cada um deles.

\subsubsection{Resultados específicos para o entrevistado "1"}

Esse produtor, conforme caracterizado anteriormente, utiliza embalagens de madeira tipo "M" para envio de suas frutas (considerada para esta análise a variedade Pêra, pois corresponde ao cultivar comercializado em maior expressão no momento em que a entrevista para coleta de dados específicos foi realizada) às CEASAs e à 
CEAGESP. Os dados específicos desse entrevistado foram coletados durante a segunda visita e encontram-se disponíveis no Apêndice 2.

Os valores então coletados foram aferidos na planilha Fazendas Reunidas Raio de Sol, op. cit., p.50, obtendo-se os respectivos porcentuais de lucro com depreciação ${ }^{18}$ para cada nível de refugo, sendo os valores dos lucros referentes à venda de uma carga de caminhão truck para os clientes CEASAs ou CEAGESP, com a utilização de embalagem de madeira tipo "M". Os resultados obtidos com os valores fornecidos pelo produtor 1 , com a embalagem utilizada, podem ser analisados na Tabela 11.

\footnotetext{
$18 \mathrm{Na}$ planilha adotada, utilizou-se lucro com depreciação na análise da viabilidade econômica das embalagens pois, considerou-se que o produtor adquiriu o maquinário para beneficiamento das frutas, sendo necessário, portanto, considerar a depreciação relativa a esse equipamento.
} 
Tabela 11.Cálculo de custo referente à utilização da embalagem de madeira tipo "M”, comprada e retornável, entrevistado "1”, 2003.

\begin{tabular}{|c|c|c|c|c|c|}
\hline $\operatorname{Refug}(\%)$ & $35.0 \%$ & $300 \%$ & $250 \%$ & $20.0 \%$ & $150 \%$ \\
\hline Perda (\%) & $2,00 \%$ & $2,00 \%$ & $2,00 \%$ & $2,00 \%$ & $2,00 \%$ \\
\hline Indústria (caixas de $40,8 \mathrm{~kg}$ ) & 103,30 & 88,50 & 73,80 & 59,00 & 44,30 \\
\hline Clientes (supermercados ou atacadistas ou CEASAs) - $\mathrm{kg}$ de citrus & 7.585 & 8.187 & 8.789 & 9.391 & 9.993 \\
\hline Total de laranjas enceradas $(\mathrm{kg})$ & 10.306 & 10.547 & 10.788 & 11.029 & 11.269 \\
\hline \multicolumn{6}{|l|}{ Receitas } \\
\hline Total de Fruta para o Cliente (R\$/caminhãotruck) & $\mathrm{R} \$ 4.551 .00$ & $\mathrm{R} \$ 4.912 .20$ & $\mathrm{R} \$ 5.273 .40$ & $\mathrm{R} \$ 5.634 .60$ & $\mathrm{R} \$ 5.995 .80$ \\
\hline Total de Fruta para a Indústria (R\$/caminhão truck) & $\mathrm{R} \$ 929.70$ & $\mathrm{R} \$ 796.50$ & $\mathrm{R} \$ 664.20$ & $\mathrm{R} \$ 531.00$ & $\mathrm{R} \$ 398.70$ \\
\hline Frete médio Indústria (R\$/caminhãot truck) & $(\mathrm{R} \$ 54.97)$ & $(\mathrm{R} \$ 47.10)$ & $(\mathrm{R} \$ 39.27)$ & $(\mathrm{R} \$ 31.40)$ & $(\mathrm{R} \$ 23.58)$ \\
\hline Total das receitas (R\$/caminhão truck) & $\mathrm{R} \$ 5.425 .73$ & $\mathrm{R} \$ 5.661 .60$ & $\mathrm{R} \$ 5.898 .33$ & $\mathrm{R} \$ 6.134 .20$ & $\mathrm{R} \$ 6.370 .92$ \\
\hline \multicolumn{6}{|l|}{ Despesas } \\
\hline Fruta (R\$/caminhão truck) & $\mathrm{R} \$ 3.541 .20$ & $\mathrm{R} \$ 3.541 .20$ & $\mathrm{R} \$ 3.541 .20$ & $\mathrm{R} \$ 3.541 .20$ & $\mathrm{R} \$ 3.541 .20$ \\
\hline Colheita (R\$/caminhão truck) & $\mathrm{R} \$ 354.12$ & $\mathrm{R} \$ 354.12$ & $\mathrm{R} \$ 354.12$ & $\mathrm{R} \$ 354.12$ & $\mathrm{R} \$ 354.12$ \\
\hline Frete Fazenda-Packing-House (R\$/caminhão truck) & $\mathrm{R} \$ 206.56$ & $\mathrm{R} \$ 206.56$ & $\mathrm{R} \$ 206.56$ & $\mathrm{R} \$ 206.56$ & $\mathrm{R} \$ 206.56$ \\
\hline Despesas com uso de embalagens (R\$/caminhão truck) & $\mathrm{R} \$ 84.28$ & $\mathrm{R} \$ 90.97$ & $\mathrm{R} \$ 97.66$ & $\mathrm{R} \$ 104.34$ & $\mathrm{R} \$ 111.03$ \\
\hline Despesas com embalagens retornáveis perdidas ( $\mathrm{R} \$$ /caminhão truck) & $\mathrm{R} \$ 8.43$ & $\mathrm{R} \$ 9.10$ & $\mathrm{R} \$ 9.77$ & $\mathrm{R} \$ 10.43$ & $\mathrm{R} \$ 11.10$ \\
\hline Despesas com carregamento/descarregamento (RS/caminhão truck) & $\mathrm{R} \$ 0.00$ & $\mathrm{R} \$ 0.00$ & $\mathrm{R} \$ 0.00$ & $\mathrm{R} \$ 0.00$ & $\mathrm{R} \$ 0.00$ \\
\hline Despesas com rótulos (R\$/caminhão truck) & $\mathrm{R} \$ 28.09$ & $\mathrm{R} \$ 30.32$ & $\mathrm{R} \$ 32.55$ & $\mathrm{R} \$ 34.78$ & $\mathrm{R} \$ 37.01$ \\
\hline Beneficiamento (R\$/caminhão truck) & $\mathrm{R} \$ 541.80$ & $\mathrm{R} \$ 541.80$ & $\mathrm{R} \$ 541.80$ & $\mathrm{R} \$ 541.80$ & $\mathrm{R} \$ 541.80$ \\
\hline Intermediação (R\$/caminhão truck) & $\mathrm{R} \$ 0.00$ & $\mathrm{R} \$ 0.00$ & $\mathrm{R} \$ 0.00$ & $\mathrm{R} \$ 0.00$ & $\mathrm{R} \$ 0.00$ \\
\hline Cera (R\$/caminhão truck) & $\mathrm{R} \$ 48.31$ & $\mathrm{R} \$ 49.44$ & $\mathrm{R} \$ 50.57$ & $\mathrm{R} \$ 51.70$ & $\mathrm{R} \$ 52.83$ \\
\hline Frete Packing-House - Cliente (R\$/caminhãotruck) & $\mathrm{R} \$ 189.63$ & $\mathrm{R} \$ 204.68$ & $\mathrm{R} \$ 219.73$ & $\mathrm{R} \$ 234.78$ & $\mathrm{R} \$ 249.83$ \\
\hline Despesas Diversas (R\$/caminhão truck) & $\mathrm{R} \$ 0.00$ & $\mathrm{R} \$ 0.00$ & $\mathrm{R} \$ 0.00$ & $\mathrm{R} \$ 0.00$ & $\mathrm{R} \$ 0.00$ \\
\hline Despesas ICMS/frete+ Permissão trânsito (R\$/caminhão truck) & $\mathrm{R} \$ 0.00$ & $\mathrm{R} \$ 0.00$ & $\mathrm{R} \$ 0.00$ & $\mathrm{R} \$ 0.00$ & $\mathrm{R} \$ 0.00$ \\
\hline Despesas Bancárias (R\$/caminhão truck) & $\mathrm{R} \$ 158$ & $R \$ 1.71$ & $\mathrm{R} \$ 1.83$ & $R \$ 1.96$ & $\mathrm{R} \$ \supset \cap \mathrm{nR}$ \\
\hline Funrural (R\$/caminhão truck) & $\mathrm{R} \$ 104.67$ & $\mathrm{R} \$ 112.98$ & $\mathrm{R} \$ 121.29$ & $\mathrm{R} \$ 129.60$ & $\mathrm{R} \$ 137.90$ \\
\hline Desconto Financeiro (R\$/caminhão truck ) & $\mathrm{R} \$ 0.00$ & $\mathrm{R} \$ 0.00$ & $\mathrm{R} \$ 0.00$ & $\mathrm{R} \$ 0.00$ & $\mathrm{R} \$ 0.00$ \\
\hline Custo de oportunidade da embalagem ( $\mathrm{R} \$$ /caminhão truck) & $\mathrm{R} \$ 1,12$ & $\mathrm{R} \$ 1,21$ & $\mathrm{R} \$ 1,30$ & $\mathrm{R} \$ 1,39$ & $\mathrm{R} \$ 1,48$ \\
\hline Perdas pelo uso da embalagem (R\$/caminhão truck) & $\mathrm{R} \$ 0.00$ & $\mathrm{R} \$ 0.00$ & $\mathrm{R} \$ 0.00$ & $\mathrm{R} \$ 0.00$ & $\mathrm{R} \$ 0.00$ \\
\hline Total das despesas (RS/caminhão truck) & $\mathrm{R} \$ 5.109 .79$ & $\mathrm{R} \$ 5.144 .08$ & $\mathrm{R} \$ 5.178 .37$ & $\mathrm{R} \$ 5.212 .66$ & $\mathrm{R} \$ 5.246 .94$ \\
\hline Lucro (ou preiuízo) sem depreciacão (R\$/caminhão truck) & $\mathrm{R} \$ 315.94$ & $\mathrm{R} \$ 517.52$ & $\mathrm{R} \$ 719.96$ & $\mathrm{R} \$ 921.55$ & $\mathrm{R} \$ 1.123 .98$ \\
\hline Depreciacão 8anos (R\$/caminhão truck) & $(\mathrm{R} \$ 115.27)$ & $(\mathrm{R} \$ 115.27)$ & $(\mathrm{R} \$ 115.27)$ & $(\mathrm{R} \$ 115.27)$ & $(\mathrm{R} \$ 115.27)$ \\
\hline Lucro (ou preiuízo) líquido (R\$/caminhão truck) & $\mathrm{R} \$ 200.66$ & $\mathrm{R} \$ 402.25$ & $\mathrm{R} \$ 604.69$ & $\mathrm{R} \$ 806.27$ & $\mathrm{R} \$ 1.008 .71$ \\
\hline Valor do quilo de laranja destinada ao cliente, sem depreciação ( $\mathrm{R} \$ / \mathrm{kg}$ ) & $\mathrm{R} \$ 0,56$ & $\mathrm{R} \$ 0,54$ & $\mathrm{R} \$ 0,52$ & $\mathrm{R} \$ 0,50$ & $\mathrm{R} \$ 0,49$ \\
\hline Valor do quilo de laranja destinada ao cliente, com depreciação $(\mathrm{R} \$ / \mathrm{kg})$ & $\mathrm{R} \$ 0,57$ & $\mathrm{R} \$ 0,55$ & $\mathrm{R} \$ 0,53$ & $\mathrm{R} \$ 0,51$ & $\mathrm{R} \$ 0,50$ \\
\hline Valor de venda $(\mathrm{R} \$ / \mathrm{kg})$ & $\mathrm{R} \$ 0,60$ & $\mathrm{R} \$ 0,60$ & $\mathrm{R} \$ 0,60$ & $\mathrm{R} \$ 0,60$ & $\mathrm{R} \$ 0,60$ \\
\hline Lucro (prejuízo), sem depreciação (\%) & $7,46 \%$ & $11,78 \%$ & $15,81 \%$ & $19,55 \%$ & $23,07 \%$ \\
\hline Lucro (nreimízo) com denreciacão (\%) & $4.61 \%$ & $892 \%$ & $1295 \%$ & $1670 \%$ & $2023 \%$ \\
\hline
\end{tabular}

Fonte: Fazendas Reunidas Raio de Sol, op. cit., p.50 e dados de pesquisa. 
A partir da Tabela 11, foram feitas simulações para avaliação de uso dos demais tipos de embalagens e, para isso, foram realizadas mudanças em alguns valores de determinados itens da planilha, conforme descrito a seguir.

a) Uso de embalagem plástica sob o sistema de aluguel: adotoutse o valor de $\mathrm{R}$ \$ 4,50 (R\$ 1,50 multiplicado por três), equivalente ao preço do aluguel por caixa (para o cenário 1); o valor de $15 \%$ correspondente à taxa de desconto financeiro (para o cenário 1); o valor de $\mathrm{R} \$ 2,10$ ( $\mathrm{R} \$ 0,70$ multiplicado por três) equivalente ao preço do aluguel por caixa (para os cenários 2 e 3); o valor de 3,5\% correspondente à taxa de desconto financeiro (para os cenários 2 e 3); o valor de $\mathrm{R} \$$ 7,50 por caminhão equivalente às "despesas por carregamento/descarregamento" na central do supermercado; o valor de $0,80 \%$ como sendo a taxa mensal da poupança (setembro de 2003) para o cálculo do custo de oportunidade de uso desta embalagem; valores nulos para os itens "despesas com embalagens retornáveis perdidas", "despesas com rótulos" (estando esses incluídos nas despesas obtidas com beneficiamento) e "perdas pelo uso da embalagem".

b) Uso de embalagem de papelão: adotourse o valor de $\mathrm{R} \$ 2,00$ referente ao preço da embalagem de papelão; o valor de 0,80\% como sendo a taxa mensal da poupança (setembro de 2003) para o cálculo do custo de oportunidade de uso da referida embalagem; valores nulos para os itens "desconto financeiro", "despesas com carregamento/descarregamento" na central do supermercado, "despesas com embalagens retornáveis perdidas", "despesas com rótulos" (uma vez que as informações do produtor poderão ser impressas na própria embalagem) e "perdas pelo uso da embalagem".

c) Uso de embalagens plásticas compradas retornáveis: adotourse o valor de $\mathrm{R} \$ 10,00$ referente ao preço da embalagem de "plástico comprada", e, neste mesmo item, considerou-se o valor de 60 viagens de retorno da embalagem; o valor de $2 \%$ referente ao nível de perdas de embalagens retornáveis; o valor de $\mathrm{R} \$ 0,10$ por embalagem referente às despesas com rótulos; o valor de $0,80 \%$ como sendo a taxa mensal da poupança (setembro de 2003) para o cálculo do custo de oportunidade de uso da referida embalagem; valores nulos foram atribuídos aos itens "desconto financeiro", 
"despesas com carregamento/descarregamento" na central do supermercado e "perdas pelo uso da embalagem".

Assim, aferiram-se os mesmos valores fornecidos pelo entrevistado "1" na planilha por mais três vezes, sendo que, em cada uma das simulações, consideraram-se valores referentes a cada tipo de embalagem (diferentes daquela utilizada, de fato, pelo entrevistado " 1 ").

A partir dos resultados ilustrados com a Tabela 11 (referente à embalagem utilizada na realidade) e também dos obtidos a partir das simulações adicionais (referentes ao uso dos demais tipos de embalagens), obtiveram-se os níveis porcentuais de lucro com depreciação para cada nível de refugo, permitindo a comparação de uso de diferentes tipos de embalagens para o produtor “1”, conforme ilustra a Tabela 12.

Tabela 12. Nível porcentual de lucro com depreciação para os diferentes tipos de embalagens e respectivos sistemas, em diferentes níveis de refugo, referentes ao entrevistado "1", cenário 1, 2003.

\begin{tabular}{lccccc}
\hline \multicolumn{1}{c}{ Embalagens } & \multicolumn{5}{c}{ Níveis de Refugo } \\
& $35 \%$ & $30 \%$ & $25 \%$ & $20 \%$ & $15 \%$ \\
\hline Plástica (comprada retornável) & 5,64 & 10,03 & 14,15 & 17,98 & 21,59 \\
Madeira (retornável) & 4,61 & 8,92 & 12,95 & 16,70 & 20,23 \\
Papelão (descartável) & $(10,38)$ & $(7,23)$ & $(4,33)$ & $(1,65)$ & 0,84 \\
Plástica (aluguel) & $(11,30)$ & $(8,22)$ & $(5,38)$ & $(2,76)$ & $(0,33)$ \\
\hline
\end{tabular}

Fonte: dados de pesquisa.

Analisando-se a Tabela 12, observa-se que as embalagens de madeira e de "plástico comprada" são as mais viáveis para o entrevistado "1", em todos os níveis de refugo, sendo esta última a que se destaca perante todas as alternativas de embalagens. Como terceira opção, esse entrevistado poderia estar utilizando a embalagem de papelão, 
porém somente se admitindo um nível de $15 \%$ de refugo. Logo, se utilizasse a embalagem de papelão sob os níveis de refugo correspondentes a 35\%, 30\%, $25 \%$ e $20 \%$, ou ainda se utilizasse a embalagem plástica sob o sistema de aluguel em qualquer nível de refugo, esse produtor estaria observando prejuízos com a venda de uma carga de caminhão truck de laranjas.

Cabe salientar que embalagens plásticas sob o sistema de aluguel são utilizadas somente por clientes como supermercados (que representam uma despesa adicional referente à taxa de desconto financeiro). Na Tabela 12, consideraram-se resultados referentes ao cenário 1 , ou seja, a porcentagem de lucro obtido com a venda de frutas ao supermercado em questão (quando se utiliza embalagem plástica sob o sistema de aluguel) refere-se a um supermercado pertencente a uma das grandes redes, como Pão-de-Açúcar, por exemplo. Assim, a taxa de desconto financeiro exigida por esse tipo de supermercado equivale a $15 \%$ e o valor do aluguel de cada embalagem corresponde a $\mathrm{R} \$ 1,50$. Para o cenário 1 , pode-se concluir então que não é lucrativa a venda de laranjas (no caso, variedade Pêra) aos supermercados de grandes redes, ou seja, não é recomendado o uso de embalagens plásticas sob sistema de aluguel, para qualquer nível de refugo. Por outro lado, se o produtor vender suas frutas para clientes que não sejam supermercados, como, por exemplo, CEASAs, CEAGESP ou outros atacadistas, em que não se aplicam taxas de desconto financeiro, ele obterá lucro. Esse lucro pode ser observado utilizando-se tanto embalagens de madeira como de "plástico comprada", para qualquer nível de refugo, ou ainda, utilizando embalagem de papelão mas somente para o nível de refugo de $15 \%$. Para obtenção de maior viabilidade econômica de uso, o produtor, no cenário 1, deveria utilizar a embalagem de "plástico comprada", preferencialmente para o nível de refugo de $15 \%$.

Existem supermercados que pertencem a pequenas redes, em que a taxa de desconto financeiro corresponde a 3,5\% e o valor do aluguel de cada embalagem plástica equivale a $\mathrm{R} \$ 0,70$, sendo esses valores significativamente menores que os cobrados por supermercados pertencentes às grandes redes. 
Para esse contexto, tem-se o cenário 2 , em que se considera que o entrevistado " 1 " vende laranjas da variedade Pêra para supermercados pertencentes às pequenas redes, quando simuladas informações na planilha para uso de embalagem plástica de aluguel. Assim, na Tabela 13, observam-se diferentes valores de porcentagens de lucro com depreciação, ao se considerar embalagem plástica sob o sistema de aluguel.

Tabela 13. Nível porcentual de lucro com depreciação para os diferentes tipos de embalagens e respectivos sistemas, em diferentes níveis de refugo, referentes ao entrevistado "1", cenário 2, 2003.

\begin{tabular}{lccccc}
\multicolumn{1}{c}{ Embalagens } & \multicolumn{5}{c}{ Níveis de Refugo } \\
& $35 \%$ & $30 \%$ & $25 \%$ & $20 \%$ & $15 \%$ \\
\hline Plástica (comprada retornável) & 5,64 & 10,03 & 14,15 & 17,98 & 21,59 \\
Madeira (retornável) & 4,61 & 8,92 & 12,95 & 16,70 & 20,23 \\
Plástica (aluguel) & 1,30 & 5,33 & 9,09 & 12,59 & 15,87 \\
Papelão (descartável) & $(10,38)$ & $(7,23)$ & $(4,33)$ & $(1,65)$ & 0,84 \\
\hline
\end{tabular}

Fonte: dados de pesquisa.

Observa-se, a partir da Tabela 13, que ao se utilizar embalagem plástica alugada, ou seja, ao vender suas frutas ao supermercado, que neste caso pertence a uma pequena rede, o produtor poderá estar obtendo lucro em qualquer nível de refugo, ou ainda, se ele vender laranjas ao setor supermercadista, compensaria vender aos supermercados pertencentes às pequenas redes. No entanto, considerando-se as demais alternativas de embalagens e clientes, seria ainda mais lucrativo se esse entrevistado vendesse suas frutas a outros tipos de clientes, como atacadistas, CEASAs e CEAGESP, utilizando-se de embalagens como as de madeira tipo "M" ou as de "plástico comprada" (preferencialmente). Como terceira alternativa, no cenário 2, deveria haver mais vendas 
de frutas para supermercados de pequenas redes (utilizando-se embalagens plásticas sob o sistema de aluguel). Na seqüência, somente deveria ser descartada a hipótese de vender suas frutas a clientes como os atacadistas, as CEASAs e a CEAGESP, se ocorresse o uso da embalagem de papelão, mesmo sob o nível de refugo $15 \%$ (único nível lucrativo para essa alternativa).

Se o produtor insistisse em vender frutas somente para supermercados, temse o cenário 3. Para esse cenário, considera-se que o produtor deseja vender suas frutas para redes supermercadistas tendo como alternativa, todos os tipos de embalagens consideradas neste estudo. Para que esse fato ocorra, é necessário que o supermercado, considerado cliente, pertença a pequenas redes, pois os pertencentes às grandes redes somente aceitam laranjas em embalagens plásticas sob o sistema de aluguel. Assim, foram aferidas despesas referentes à taxa de desconto financeiro (3,5\%), nos cálculos das planilhas de cada uma das simulações referentes ao uso de cada tipo de embalagem. Os resultados podem ser observados na Tabela 14 .

Tabela 14. Nível porcentual de lucro com depreciação para os diferentes tipos de embalagens e respectivos sistemas, em diferentes níveis de refugo, referentes ao entrevistado "1", cenário 3, 2003.

\begin{tabular}{lccccc}
\hline \multicolumn{1}{c}{ Embalagens } & \multicolumn{5}{c}{ Níveis de Refugo } \\
& $35 \%$ & $30 \%$ & $25 \%$ & $20 \%$ & $15 \%$ \\
\hline Plástica (comprada retornável) & 1,87 & 5,95 & 9,77 & 13,30 & 16,62 \\
Plástica (aluguel) & 1,30 & 5,33 & 9,09 & 12,59 & 15,87 \\
Madeira (retornável) & 0,92 & 4,92 & 8,66 & 12,12 & 15,37 \\
Papelão (descartável) & $(13,10)$ & $(10,15)$ & $(7,43)$ & $(4,92)$ & $(2,59)$ \\
\hline
\end{tabular}

Fonte: dados de pesquisa.

Considerando os dados da Tabela 14, observa-se que, se o produtor insistisse em vender suas laranjas apenas para o setor supermercadista, no caso, pertencente às 
pequenas redes, ele ainda continuaria observando o maior nível de lucro utilizando-se de embalagens de "plástico comprada", em qualquer nível de refugo. Nesse cenário, como segunda opção, ele poderia vender suas frutas utilizando-se de embalagens plásticas sob o sistema de aluguel, e como terceira alternativa, utilizar a embalagem de madeira, sendo ambas as opções viáveis em qualquer nível de refugo. Já a embalagem de papelão, no cenário 3, apresenta-se inviável, mesmo sob o nível de refugo $15 \%$, que em outros cenários apresentou-se viável.

Para melhor avaliação da viabilidade de uso de embalagens, deve-se considerar as perdas nos frutos proporcionadas pela utilização de cada tipo de embalagem. No entanto, para este estudo de caso, em que o cliente (atacadistas, CEASAs ou CEAGESP) se localiza a uma distância média de $150 \mathrm{~km}$ a partir do Packing-House (Apêndice 2), não se consideram despesas referentes às perdas proporcionadas pela utilização de embalagens de papelão e de madeira "M", uma vez que tais perdas são consideradas significativas somente para distâncias acima de 1.000 $\mathrm{km}^{19}$.

Se essas despesas fossem consideradas, ou seja, se o entrevistado "1" apresentasse clientes distantes a pelo menos $1.000 \mathrm{~km}$ da unidade de beneficiamento, seriam observadas, além de maiores despesas referentes ao custo das embalagens de madeira e de papelão, maiores despesas referentes ao custo do frete a partir do PackingHouse até o cliente. Ao se atualizar os cálculos devidos que considerem os índices de perdas, poderiam observar-se menores valores de lucro com depreciação em todos os níveis de refugo nas simulações realizadas com todos os tipos de embalagens, principalmente com as de papelão e de madeira, que apresentariam valores de despesas adicionais relativas às perdas por utilização, implicando variações no ranking de classificação das embalagens nos cenários considerados.

\footnotetext{
19 Estimativas de perdas fornecidas pelos produtores entrevistados e pelo Instituto de Pesquisas Tecnológicas (IPT), 2003.
} 


\subsubsection{Resultados específicos para o entrevistado " 2 "}

Esse entrevistado se caracteriza principalmente por vender laranjas de variedade Murcote para clientes (atacadistas) da região Nordeste, localizados a mais de $1.000 \mathrm{~km}$ da unidade de beneficiamento. Tem utilizado, para atender a esse mercado, embalagens de papelão $(18 \mathrm{~kg})$, sendo que o valor do frete é de responsabilidade do cliente. Embora esse produtor venda suas laranjas em outros tipos de embalagens, a de papelão é a única que ele se responsabiliza pelas despesas de utilização, sendo o uso desse tipo de embalagem considerado como o caso real deste estudo de caso.

Durante a segunda visita realizada a esse entrevistado, coletaram-se então dados específicos referentes às despesas e receitas obtidas a partir da compra de uma carga de caminhão truck da fazenda, e da venda da mesma para clientes como atacadistas (neste caso), considerando-se despesas referentes ao uso da embalagem de papelão e com beneficiamento, entre outras. Os dados específicos desse entrevistado encontram-se no Apêndice 3.

Assim, conforme realizado para o entrevistado "1", serão também neste caso conduzidas simulações utilizando-se outros tipos de embalagens, além da utilizada de fato pelo produtor "2", no caso, a embalagem de papelão (18 kg). Dessa forma, por meio da Tabela 15, pode-se observar os resultados de lucro com depreciação obtidos (para os diversos níveis de refugo), a partir da aferição de dados coletados durante a segunda visita. 
Tabela 15. Cálculo de custo referente à utilização da embalage m de papelão (18 kg), entrevistado “2”, 2003.

\begin{tabular}{|c|c|c|c|c|c|}
\hline Refugo (\%) & $35,0 \%$ & $30.0 \%$ & $25.0 \%$ & $20.0 \%$ & $15.0 \%$ \\
\hline Perda (\%) & $2,00 \%$ & $2,00 \%$ & $2,00 \%$ & $2,00 \%$ & $2,00 \%$ \\
\hline Indústria (caixas de 40,8 kg) & 103,30 & 88,50 & 73,80 & 59,00 & 44,30 \\
\hline Clientes (supermercados ou atacadistas ou CEASAs) - $\mathrm{kg}$ de citrus & 7.585 & 8.187 & 8.789 & 9.391 & 9.993 \\
\hline Total de laranjas enceradas $(\mathrm{kg})$ & 10.306 & 10.547 & 10.788 & 11.029 & 11.269 \\
\hline \multicolumn{6}{|l|}{ Receitas } \\
\hline Total de Fruta para o Cliente (R\$/caminhão truck) & $\mathrm{R} \$ 4.171,75$ & $\mathrm{R} \$ 4.502,85$ & $\mathrm{R} \$ 4.833,95$ & $\mathrm{R} \$ 5.165,05$ & $\mathrm{R} \$ 5.496,15$ \\
\hline Total de Fruta para a Indústria (R\$/caminhão truck) & $\mathrm{R} \$ 991.68$ & $\mathrm{R} \$ 849.60$ & $\mathrm{R} \$ 708.48$ & $\mathrm{R} \$ 566.40$ & $\mathrm{R} \$ 425.28$ \\
\hline Frete médio Indústria ( $\mathrm{R} \$ / c a m i n h a ̃ o$ truck) & $(\mathrm{R} \$ 105,44)$ & $(\mathrm{R} \$ 90,33)$ & $(\mathrm{R} \$ 75,33)$ & $(\mathrm{R} \$ 60,22)$ & $(\mathrm{R} \$ 45,22)$ \\
\hline Total das receitas ( $\mathrm{R} \$$ /caminhão truck $)$ & $\mathrm{R} \$ 5.057,99$ & $\mathrm{R} \$ 5.262,12$ & $\mathrm{R} \$ 5.467,10$ & $\mathrm{R} \$ 5.671,23$ & $\mathrm{R} \$ 5.876,21$ \\
\hline \multicolumn{6}{|l|}{ Despesas } \\
\hline Fruta (R\$/caminhão truck) & $\mathrm{R} \$ 2.951 .00$ & $\mathrm{R} \$ 2.951 .00$ & $\mathrm{R} \$ 2.951 .00$ & $\mathrm{R} \$ 2.951 .00$ & $\mathrm{R} \$ 2.951 .00$ \\
\hline Colheita (R\$/caminhão truck) & $\mathrm{R} \$ 368,88$ & $\mathrm{R} \$ 368,88$ & $\mathrm{R} \$ 368,88$ & $\mathrm{R} \$ 368,88$ & $\mathrm{R} \$ 368,88$ \\
\hline Frete Fazenda_Packing-House (R $\$ /$ caminhão truck) & $\mathrm{R} \$ 206,57$ & $\mathrm{R} \$ 206,57$ & $\mathrm{R} \$ 206,57$ & $\mathrm{R} \$ 206,57$ & $\mathrm{R} \$ 206,57$ \\
\hline Despesas com uso de embalagens (R\$/caminhão truck) & $\mathrm{R} \$ 758,50$ & $\mathrm{R} \$ 818,70$ & $\mathrm{R} \$ 878,90$ & $\mathrm{R} \$ 939,10$ & $\mathrm{R} \$ 999,30$ \\
\hline Despesas com embalagens retornáveis perdidas ( $\mathrm{R} \$$ /caminhão truck) & $\mathrm{R} \$ 0.00$ & $\mathrm{R} \$ 0.00$ & $\mathrm{R} \$ 0.00$ & $\mathrm{R} \$ 0.00$ & $\mathrm{R} \$ 0.00$ \\
\hline Despesas com carregamento/descarregamento ( $\mathrm{R} \$ / \mathrm{caminhão}$ truck) & $\mathrm{R} \$ 0,00$ & $\mathrm{R} \$ 0,00$ & $\mathrm{R} \$ 0,00$ & $\mathrm{R} \$ 0,00$ & $\mathrm{R} \$ 0,00$ \\
\hline Despesas com rótulos ( $\mathrm{R} \$ / c a m i n h a ̃ o ~ t r u c k)$ & $\mathrm{R} \$ 0,00$ & $\mathrm{R} \$ 0,00$ & $\mathrm{R} \$ 0,00$ & $\mathrm{R} \$ 0,00$ & $\mathrm{R} \$ 0,00$ \\
\hline Beneficiamento (R\$/caminhão truck) & $\mathrm{R} \$ 361,20$ & $\mathrm{R} \$ 361,20$ & $\mathrm{R} \$ 361,20$ & $\mathrm{R} \$ 361,20$ & $\mathrm{R} \$ 361,20$ \\
\hline Intermediação (R\$/caminhão truck) & $\mathrm{R} \$ 0,00$ & $\mathrm{R} \$ 0,00$ & $\mathrm{R} \$ 0,00$ & $\mathrm{R} \$ 0,00$ & $\mathrm{R} \$ 0,00$ \\
\hline Cera ( $\mathrm{R} \$ /$ caminhão truck $)$ & $\mathrm{R} \$ 46.70$ & $\mathrm{R} \$ 47.79$ & $\mathrm{R} \$ 48.88$ & $\mathrm{R} \$ 49.97$ & $\mathrm{R} \$ 51.06$ \\
\hline Frete Packing-House - Cliente (R\$/caminhão truck) & $\mathrm{R} \$ 0,00$ & $\mathrm{R} \$ 0,00$ & $\mathrm{R} \$ 0,00$ & $\mathrm{R} \$ 0,00$ & $\mathrm{R} \$ 0,00$ \\
\hline Despesas Diversas (R\$/caminhão truck ) & $\mathrm{R} \$ 0,00$ & $\mathrm{R} \$ 0,00$ & $\mathrm{R} \$ 0,00$ & $\mathrm{R} \$ 0,00$ & $\mathrm{R} \$ 0,00$ \\
\hline Despesas ICMS/frete+ Permissão trânsito (R\$/caminhão truck) & $\mathrm{R} \$ 0,00$ & $\mathrm{R} \$ 0,00$ & $\mathrm{R} \$ 0,00$ & $\mathrm{R} \$ 0,00$ & $\mathrm{R} \$ 0,00$ \\
\hline Despesas Bancárias (R\$/caminhão truck) & $\mathrm{R} \$ 1.77$ & $\mathrm{R} \$ 1.91$ & $\mathrm{R} \$ 2.05$ & $\mathrm{R} \$ 2.19$ & $\mathrm{R} \$ 2.33$ \\
\hline Funrural ( $\mathrm{R} \$ /$ caminhão truck) & $\mathrm{R} \$ 95.95$ & $\mathrm{R} \$ 103.57$ & $\mathrm{R} \$ 111.18$ & $\mathrm{R} \$ 118.80$ & $\mathrm{R} \$ 126.41$ \\
\hline Desconto Financeiro (R\$/caminhão truck) & $\mathrm{R} \$ 0,00$ & $\mathrm{R} \$ 0,00$ & $\mathrm{R} \$ 0,00$ & $\mathrm{R} \$ 0,00$ & $\mathrm{R} \$ 0,00$ \\
\hline Custo de oportunidade da embalagem ( $\mathrm{R} \$$ /caminhão truck) & $\mathrm{R} \$ 6,07$ & $\mathrm{R} \$ 6,55$ & $\mathrm{R} \$ 7,03$ & $\mathrm{R} \$ 7,51$ & $\mathrm{R} \$ 7,99$ \\
\hline Perdas pelo uso da embalagem (R\$/caminhão truck ) & $\mathrm{R} \$ 83,44$ & $\mathrm{R} \$ 90,06$ & $\mathrm{R} \$ 96,68$ & $\mathrm{R} \$ 103,30$ & $\mathrm{R} \$ 109,92$ \\
\hline Total das despesas (R\$/caminhão truck) & $\mathrm{R} \$ 4.880 .07$ & $\mathrm{R} \$ 4.956 .22$ & $\mathrm{R} \$ 5.032 .37$ & $\mathrm{R} \$ 5.108 .52$ & $\mathrm{R} \$ 5.184 .67$ \\
\hline Lucro (ou prejuízo) sem depreciação (R\$/caminhão truck) & $\mathrm{R} \$ 177,92$ & $\mathrm{R} \$ 305,90$ & $\mathrm{R} \$ 434,73$ & $\mathrm{R} \$ 562,71$ & $\mathrm{R} \$ 691,54$ \\
\hline Depreciação 8anos (R\$/caminhão truck) & $(\mathrm{R} \$ 115,27)$ & $(\mathrm{R} \$ 115,27)$ & $(\mathrm{R} \$ 115,27)$ & $(\mathrm{R} \$ 115,27)$ & $(\mathrm{R} \$ 115,27)$ \\
\hline Lucro (ou prejuízo) líquido (R\$/caminhão truck) & $\mathrm{R} \$ 62,65$ & $\mathrm{R} \$ 190,63$ & $\mathrm{R} \$ 319,46$ & $\mathrm{R} \$ 447,44$ & $\mathrm{R} \$ 576,27$ \\
\hline Valor do quilo de laranja destinada ao cliente, sem depreciação ( $\mathrm{R} \$ / \mathrm{kg}$ ) & $\mathrm{R} \$ 0,53$ & $\mathrm{R} \$ 0,51$ & $\mathrm{R} \$ 0,50$ & $\mathrm{R} \$ 0,49$ & $\mathrm{R} \$ 0,48$ \\
\hline Valor do quilo de laranja destinada ao cliente, com depreciação $(\mathrm{R} \$ / \mathrm{kg})$ & $\mathrm{R} \$ 0,54$ & $\mathrm{R} \$ 0,53$ & $\mathrm{R} \$ 0,51$ & $\mathrm{R} \$ 0,50$ & $\mathrm{R} \$ 0,49$ \\
\hline Valor de venda $(\mathrm{R} \$ / \mathrm{kg})$ & $\mathrm{R} \$ 0,55$ & $\mathrm{R} \$ 0,55$ & $\mathrm{R} \$ 0,55$ & $\mathrm{R} \$ 0,55$ & $\mathrm{R} \$ 0,55$ \\
\hline Lucro (prejuízo), sem depreciação (\%) & $4,45 \%$ & $7,29 \%$ & $9,88 \%$ & $12,23 \%$ & $14,39 \%$ \\
\hline Lucro (prejuízo). com depreciacão (\%) & $1.52 \%$ & $4.42 \%$ & $7.08 \%$ & $9.48 \%$ & $11.71 \%$ \\
\hline
\end{tabular}

Fonte: Fazendas Reunidas Raio de Sol, op. cit., p.50 e dados de pesquisa. 
Assim, a partir da Tabela 15, foram feitas simulações para avaliação de uso dos demais tipos de embalagens e, para isso, foram realizadas mudanças em alguns valores de determinados itens da planilha, conforme descrito a seguir.

a) Uso de embalagem plástica sob o sistema de aluguel: adotour se o valor de $\mathrm{R} \$$ 4,50 ( $\mathrm{R}$ \$ 1,50 multiplicado por três) equivalente ao preço do aluguel por caixa (para o cenário 1); o valor de $15 \%$ correspondente à taxa de desconto financeiro (para o cenário 1); o valor de $\mathrm{R} \$ 2,10$ ( $\mathrm{R} \$ 0,70$ multiplicado por três) equivalente ao preço do aluguel por caixa (para os cenários 2 e 3); o valor de 3,5\% correspondente à taxa de desconto financeiro (para os cenários 2 e 3); o valor de $\mathrm{R} \$$ 7,50 por caminhão equivalente às "despesas por carregamento/descarregamento" na central do supermercado; o valor de $0,80 \%$ como sendo a taxa mensal da poupança (setembro de 2003) para o cálculo do custo de oportunidade de uso desta embalagem; valores nulos para os itens "despesas com embalagens retornáveis perdidas", "despesas com rótulos" (estando esses incluídos nas despesas obtidas com beneficiamento) e "perdas pelo uso da embalagem".

b) Uso de embalagem de madeira tipo "M": adotoutse o valor de R $\$ 3,00$ referente ao preço da embalagem de madeira e, neste mesmo item, considerourse o valor de 10 viagens de retorno da embalagem; o valor de $10 \%$ referente ao nível de perdas de embalagens retornáveis; o valor de R $\$ 0,10$ para despesas com rótulos; o valor de $10 \%$ referente às perdas pela utilização da embalagem de madeira; o valor de $0,80 \%$ como sendo a taxa mensal da poupança (setembro de 2003) para o cálculo do custo de oportunidade de uso da referida embalagem; valores nulos para os itens "despesas com carregamento/descarregamento" na central do supermercado e "desconto financeiro".

c) Uso de embalagens plásticas compradas retornáveis: adotourse o valor de $\mathrm{R} \$ 10,00$ referente ao preço da embalagem de "plástico comprada" e, neste mesmo item, considerou-se o valor de 60 viagens de retorno da embalagem; o valor de $2 \%$ referente ao nível de perdas de embalagens retornáveis; o valor de $\mathrm{R} \$ 0,10$ por embalagem referente às despesas com rótulos; o valor de 0,80\% como sendo a taxa mensal da poupança (setembro de 2003) para o cálculo do custo de oportunidade de uso da referida 
embalagem; valores nulos foram atribuídos aos itens "desconto financeiro", "despesas com carregamento/descarregamento" na central do supermercado e "perdas pelo uso da embalagem".

Segundo os próprios entrevistados, não se observam perdas significativas (então consideradas nulas) em laranjas transportadas em embalagens plásticas pelo fato dessas embalagens serem resistentes, de superfície lisa (não ferem o fruto), altamente ventiladas e paletizáveis, não se deslocando com os movimentos bruscos do caminhão. Já as embalagens de papelão e as de madeira proporcionam níveis específicos de perdas em laranjas por elas embaladas, sendo essas perdas observadas somente quando as frutas são transportadas por distâncias superiores a $1.000 \mathrm{~km}$. Conforme os entrevistados, observam-se perdas relativas a $2 \%$ do total de frutas transportadas em um caminhão truck, por embalagens de papelão (devido à má circulação de ar dentro delas e à baixa capacidade de empilhamento se comparada às embalagens de madeira e de plástico). Já no caso das embalagens de madeira, observam-se perdas de até $10 \%$ no total da carga (embora elas permitam boa ventilação dos frutos, apresenta baixa estabilidade de pilha, por não ser paletizáveis, esmagando os frutos, principalmente quando as condições das estradas são ruins).

Com a aferição dos dados reais do entrevistado "2", a partir da Tabela 15, foram realizadas simulações com utilização das demais embalagens, a partir das considerações citadas nos parágrafos anteriores. Dessa forma, considerando-se o cenário 1, o produtor possui as seguintes alternativas: utilizar a embalagem de plástico sob o sistema de aluguel e vender suas frutas para supermercados de grandes redes (cuja taxa de desconto financeiro equivale a $15 \%$ e o aluguel por caixa equivale a um valor de $\mathrm{R} \$$ 1,50 multiplicado por três) ou vender laranjas para outros clientes que não sejam supermercados, como, por exemplo, atacadistas, utilizando-se de embalagens de "plástico compradas", de madeira tipo "M" ou de papelão (que é o caso real desse entrevistado, o qual vende suas frutas para atacadistas situados na região Nordeste).

O resultado dessas considerações em Fazendas Reunidas Raio de Sol, op. cit., p.50, no cenário 1 , diz respeito à obtenção das porcentagens de lucro com 
depreciação (para cada nível de refugo), obtidas com a venda de laranjas de variedade Murcote, a partir de uma carga de caminhão truck vinda da fazenda produtora, considerando-se o uso de cada tipo de embalagem, conforme ilustram os resultados observados na Tabela 16.

Tabela 16. Nível porcentual de lucro com depreciação para os diferentes tipos de embalagens e respectivos sistemas, em diferentes níveis de refugo, referentes ao entrevistado "2", cenário 1, considerando-se perdas por utilização de embalagens de papelão e madeira, 2003.

\begin{tabular}{lccccc}
\hline \multicolumn{1}{c}{ Embalagens } & \multicolumn{5}{c}{ Níveis de Refugo } \\
& $35 \%$ & $30 \%$ & $25 \%$ & $20 \%$ & $15 \%$ \\
\hline Plástica (comprada retornável) & 24,88 & 29,29 & 33,38 & 37,14 & 40,66 \\
Madeira (retornável) & 9,78 & 13,17 & 16,30 & 19,14 & 21,79 \\
Plástica (aluguel) & 1,59 & 4,49 & 7,14 & 9,56 & 11,79 \\
Papelão (descartável) & 1,52 & 4,42 & 7,08 & 9,48 & 11,71 \\
\hline
\end{tabular}

Fonte: dados de pesquisa.

Observa-se, por meio da Tabela 16, que o produtor 2 apresenta lucro (para qualquer nível de refugo) ao utilizar qualquer uma das alternativas de embalagem e respectivos sistemas. Tal ocorrência poderia ser explicada pelo fato de considerar, para este estudo de caso, que o cliente é o responsável pelas despesas relacionadas ao valor do frete das frutas a partir do Packing-House. Assim, o valor da despesa total para o entrevistado "2" é significativamente reduzido, uma vez que o frete representa um valor considerável, dado que o cliente se situa a aproximadamente $1.970 \mathrm{~km}$ da unidade de beneficiamento desse produtor.

Embora na realidade seja utilizada a embalagem de papelão e esta lhe apresente lucro em qualquer nível de refugo, ao considerar alternativas de embalagens, observa-se que papelão é a terceira alternativa mais viável. Dessa forma, seria mais 
viável que este produtor vendesse laranjas a clientes como os atacados, as CEASAs ou a CEAGESP utilizando-se, como primeira alternativa, a embalagem de "plástico comprada" e, como segunda opção, a de madeira "M". Como alternativa menos viável, o produtor poderia vender suas frutas a supermercados pertencentes às grandes redes (Carrefour, por exemplo), utilizando-se da embalagem plástica sob o sistema de aluguel.

$\mathrm{Na}$ sequiência, considerando-se as abordagens do cenário 2, tem-se que o produtor poderá estar vendendo suas frutas a supermercados pertencentes às pequenas redes (sendo 3,5\% a taxa de desconto financeiro e $\mathrm{R} \$ 2,10$ /caixa o valor do aluguel) ou ainda vender laranjas Murcote para atacadistas ou CEASAs utilizando-se de embalagens de madeira "M", de "plástico compradas" ou de papelão. Na Tabela 17, podem ser observados os valores referentes às porcentagens de lucro com depreciação (para cada nível de refugo) dadas as simulações mencionadas.

Tabela 17. Nível porcentual de lucro com depreciação para os diferentes tipos de embalagens e respectivos sistemas, em diferentes níveis de refugo, referentes ao entrevistado "2", cenário 2, considerando-se perdas por utilização de embalagens de papelão e madeira, 2003.

\begin{tabular}{lccccc}
\hline \multicolumn{1}{c}{ Embalagens } & \multicolumn{5}{c}{ Níveis de Refugo } \\
& $35 \%$ & $30 \%$ & $25 \%$ & $20 \%$ & $15 \%$ \\
\hline Plástica (comprada retornável) & 24,88 & 29,29 & 33,38 & 37,14 & 40,66 \\
Plástica (aluguel) & 18,78 & 22,76 & 26,45 & 29,82 & 32,97 \\
Madeira (retornável) & 9,78 & 13,17 & 16,30 & 19,14 & 21,79 \\
Papelão (descartável) & 1,52 & 4,42 & 7,08 & 9,48 & 11,71 \\
\hline
\end{tabular}

Fonte: dados de pesquisa.

Por meio dos dados da Tabela 17, considerando-se agora o cenário 2, observam-se lucros a partir da utilização de quaisquer tipos de embalagens e sistemas 
para qualquer um dos níveis de refugo considerados. A opção mais viável para esse produtor, no cenário 2, seria a venda de laranjas para atacadistas ou CEASAs, utilizando-se a embalagem "plástica comprada" e, como segunda alternativa, a venda de suas frutas para supermercados pertencentes às pequenas redes, utilizando-se embalagens plásticas sob o sistema de aluguel. Como terceira opção, observa-se a embalagem de madeira tipo "M" e, como alternativa menos viável, o uso da embalagem de papelão.

Considera-se então o cenário 3, em que o produtor estaria vendendo suas frutas apenas para o cliente supermercado. Nesse caso, esse cliente corresponderia a supermercados pertencentes às pequenas redes, pois são somente estes que admitem o uso de outras embalagens e sistemas alternativos, além do sistema de aluguel de caixas plásticas. Assim, para fins comparativos de utilização de embalagens, considera-se, em cada simulação da planilha, a taxa de desconto financeiro de 3,5\%, obtendo-se, de acordo com a Tabela 18, valores referentes às porcentagens de lucro com depreciação (para cada nível de refugo) dadas as utilizações de diferentes tipos de emb alagens.

Tabela 18. Nível porcentual de lucro com depreciação para os diferentes tipos de embalagens e respectivos sistemas, em diferentes níveis de refugo, referentes ao entrevistado “2”, cenário 3, considerando-se perdas por utilização de embalagens de papelão e madeira, 2003.

\begin{tabular}{lccccc}
\hline \multicolumn{1}{c}{ Embalagens } & \multicolumn{5}{c}{ Níveis de Refugo } \\
& $35 \%$ & $30 \%$ & $25 \%$ & $20 \%$ & $15 \%$ \\
\hline Plástica (comprada retornável) & 19,65 & 23,69 & 37,43 & 30,86 & 34,06 \\
Plástica (aluguel) & 18,78 & 22,76 & 26,45 & 29,82 & 32,97 \\
Madeira (retornável) & 5,72 & 8,86 & 11,75 & 14,37 & 16,81 \\
Papelão (descartável) & $(1,96)$ & 0,74 & 3,21 & 5,44 & 7,51 \\
\hline
\end{tabular}

Fonte: dados de pesquisa. 
Por meio dos valores porcentuais de lucro com depreciação demonstrados na Tabela 18, observa-se que a única alternativa para a qual o produtor estaria observando prejuízo seria aquela relacionada à utilização da embalagem de papelão sob o nível de refugo de 35\%. Nota-se que a embalagem "plástica comprada" apresenta-se como a alternativa mais viável ao fornecer laranjas para supermercados de pequenas redes e, como segunda opção, apresenta-se a embalagem plástica sob o sistema de aluguel. Ao considerar os níveis de perdas proporcionados pelo uso das embalagens de madeira e de papelão, percebe-se que a terceira opção mais viável se refere à embalagem de madeira "M", prevalecendo a de papelão como a menos viável sob os níveis de refugo de $15 \%$ a $30 \%$, e como inviável considerando-se o nível de refugo de $35 \%$.

Dessa forma, se esse entrevistado vendesse suas laranjas apenas para supermercados de pequenas redes, considerando-se a taxa de desconto financeiro $(3,5 \%)$

para todas as simulações relacionadas ao uso de todos os tipos de embalagens, tem-se que esse produtor obteria maiores porcentagens de lucro com depreciação (em todos os níveis de refugo) se ele utilizasse embalagens "plásticas compradas". Se utilizasse a embalagem de papelão poderia obter menores índices de lucro ou ainda prejuízo, se usasse essa embalagem sob o nível de refugo de $35 \%$.

\subsubsection{Resultados específicos do entrevistado “ 3 ”}

Conforme já caracterizado, esse entrevistado vende laranjas de variedade Pêra para o Pão-de-Açúcar, supermercado pertencente a uma grande rede. Para tal, o produtor utiliza-se de embalagens plásticas sob o sistema de aluguel. A análise de viabilidade do uso desse tipo de embalagem, de acordo com seu respectivo sistema, foi feita com dados aferidos na planilha Fazendas Reunidas Raio de Sol, op. cit., p.50, obtendo-se como resultado os valores de lucro com depreciação, mostrados na Tabela 19. Os dados específicos desse produtor foram coletados durante a segunda visita realizada (vide Apêndice 4) e, a partir disso, foram também realizadas análises de viabilidade de uso dos demais tipos de embalagens, a partir de simulações por meio dos cenários 1,2 e 3, até então considerados. Logo, pôde-se estabelecer para esse estudo de caso qual é a embalagem mais viável sob o ponto de vista econômico de utilização em 
cada um dos cenários considerados, para cada nível de refugo em questão e para determinados clientes (supermercados ou atacadistas, por exemplo). 
Tabela 19. Cálculo de custo referente à utilização da embalagem de plástico (20 kg), sob o sistema de aluguel, entrevistado " 3 ".

\begin{tabular}{|c|c|c|c|c|c|}
\hline Refugo (\%) & $350 \%$ & $30.0 \%$ & $25.0 \%$ & $200 \%$ & $150 \%$ \\
\hline Perda $(\%)$ & $2,00 \%$ & $2,00 \%$ & $2,00 \%$ & $2,00 \%$ & $2,00 \%$ \\
\hline Indústria (caixas de 40,8kg) & 103,30 & 88,50 & 73,80 & 59,00 & 44,30 \\
\hline Clientes (supermercados ou atacadistas ou CEASAs) - $\mathrm{kg}$ de citrus & 7.585 & 8.187 & 8.789 & 9.391 & 9.993 \\
\hline Total de laranjas enceradas $(\mathrm{kg})$ & 10.306 & 10.547 & 10.788 & 11.029 & 11.269 \\
\hline \multicolumn{6}{|l|}{ Receitas } \\
\hline Total de Fruta para o Cliente (R\$/caminhão truck ) & $\mathrm{R} \$ 4.171,75$ & $\mathrm{R} \$ 4.502,85$ & $\mathrm{R} \$ 4.833,95$ & $\mathrm{R} \$ 5.165,05$ & $\mathrm{R} \$ 5.496,15$ \\
\hline Total de Fruta para a Indústria (R\$/caminhão truck ) & $\mathrm{R} \$ 1.012 .34$ & $\mathrm{R} \$ 867.30$ & $\mathrm{R} \$ 723.24$ & $\mathrm{R} \$ 578.20$ & $\mathrm{R} \$ 434.14$ \\
\hline Frete médio Indústria (R\$/caminhão truck) & $(\mathrm{R} \$ 60.47)$ & $(\mathrm{R} \$ 51.81)$ & $(\mathrm{R} \$ 43.20)$ & $(\mathrm{R} \$ 34.54)$ & ( $\mathrm{R} \$ 25.93)$ \\
\hline Total das receitas (R\$/caminhão truck) & $\mathrm{R} \$ 5.123 .62$ & $\mathrm{R} \$ 5.318 .34$ & $\mathrm{R} \$ 5.513 .99$ & $\mathrm{R} \$ 5.708 .71$ & $\mathrm{R} \$ 5.904 .36$ \\
\hline \multicolumn{6}{|l|}{ Despesas } \\
\hline Fruta (RS/caminhão truck) & $\mathrm{R} \$ 2.803 .45$ & $\mathrm{R} \$ 2.803 .45$ & $\mathrm{R} \$ 2.803 .45$ & $\mathrm{R} \$ 2.803 .45$ & $\mathrm{R} \$ 2.803 .45$ \\
\hline Colheita (R\$/caminhão truck) & $\mathrm{R} \$ 324.61$ & $\mathrm{R} \$ 324.61$ & $\mathrm{R} \$ 324.61$ & $\mathrm{R} \$ 324.61$ & $\mathrm{R} \$ 324.61$ \\
\hline Frete Fazenda-Packing-House (R\$/caminhão truck) & $\mathrm{R} \$ 120.00$ & $\mathrm{R} \$ 120.00$ & $\mathrm{R} \$ 120.00$ & $\mathrm{R} \$ 120.00$ & $\mathrm{R} \$ 120.00$ \\
\hline Despesas com uso de embalagens ( $\mathrm{R} \$ /$ caminhão truck) & $\mathrm{R} \$ 213.33$ & $\mathrm{R} \$ 230.26$ & $\mathrm{R} \$ 247.19$ & $\mathrm{R} \$ 264.12$ & $\mathrm{R} \$ 281.05$ \\
\hline Despesas com embalagens retornáveis perdidas ( $\mathrm{R} \$$ /caminhão truck ) & $\mathrm{R} \$ 0.00$ & $\mathrm{R} \$ 0.00$ & $\mathrm{R} \$ 0.00$ & $\mathrm{R} \$ 0.00$ & $\mathrm{R} \$ 0.00$ \\
\hline Despesas com carregamento/descarregamento (R\$/caminhão truck) & $\mathrm{R} \$ 4.74$ & $\mathrm{R} \$ 5.12$ & $\mathrm{R} \$ 5.49$ & $\mathrm{R} \$ 5.87$ & $\mathrm{R} \$ 6.25$ \\
\hline Despesas com rótulos ( $\mathrm{R} \$ /$ caminhão truck) & $\mathrm{R} \$ 0.00$ & $\mathrm{R} \$ 0.00$ & $\mathrm{R} \$ 0.00$ & $\mathrm{R} \$ 0.00$ & $\mathrm{R} \$ 0.00$ \\
\hline Beneficiamento (R\$/caminhão truck) & $\mathrm{R} \$ 963.20$ & $\mathrm{R} \$ 963.20$ & $\mathrm{R} \$ 963.20$ & $\mathrm{R} \$ 963.20$ & $\mathrm{R} \$ 963.20$ \\
\hline Intermediação (R\$/caminhão truck) & $\mathrm{R} \$ 62.58$ & $\mathrm{R} \$ 67.54$ & $\mathrm{R} \$ 72.51$ & $\mathrm{R} \$ 77.48$ & $\mathrm{R} \$ 82.44$ \\
\hline Cera (R\$/caminhão truck) & $\mathrm{R} \$ 37.36$ & $\mathrm{R} \$ 38.23$ & $\mathrm{R} \$ 39.11$ & $\mathrm{R} \$ 39.98$ & $\mathrm{R} \$ 40.85$ \\
\hline Frete Packing-House - Cliente (R\$/caminhão truck) & $\mathrm{R} \$ 214.91$ & $\mathrm{R} \$ 231.97$ & $\mathrm{R} \$ 249.02$ & $\mathrm{R} \$ 266.08$ & $\mathrm{R} \$ 283.14$ \\
\hline Despesas Diversas (R\$/caminhão truck) & $\mathrm{R} \$ 37.93$ & $\mathrm{R} \$ 40.94$ & $\mathrm{R} \$ 43.95$ & $\mathrm{R} \$ 46.96$ & $R \$ 49.97$ \\
\hline Despesas ICMS/frete+ Permissão trânsito (RS/caminhão truck) & $\mathrm{R} \$ 0.00$ & $\mathrm{R} \$ 0.00$ & $\mathrm{R} \$ 0.00$ & $\mathrm{R} \$ 0.00$ & $\mathrm{R} \$ 0.00$ \\
\hline Despesas Bancárias (R\$/caminhão truck) & $\mathrm{R} \$ 0.00$ & $\mathrm{R} \$ 0.00$ & $\mathrm{R} \$ 0.00$ & $\mathrm{R} \$ 0.00$ & $\mathrm{R} \$ 0.00$ \\
\hline Funrural (R\$/caminhão truck) & $\mathrm{R} \$ 95.95$ & $\mathrm{R} \$ 103.57$ & $\mathrm{R} \$ 111.18$ & $\mathrm{R} \$ 118.80$ & $\mathrm{R} \$ 126.41$ \\
\hline Desconto Financeiro (R\$/caminhão truck) & $\mathrm{R} \$ 625.76$ & $\mathrm{R} \$ 675.43$ & $\mathrm{R} \$ 725.09$ & $\mathrm{R} \$ 774.76$ & $\mathrm{R} \$ 824.42$ \\
\hline Custo de oportunidade da embalagem ( $\mathrm{R} \$ / \mathrm{caminh} a ̃ o$ truck) & $\mathrm{R} \$ 1,71$ & $\mathrm{R} \$ 1,84$ & $\mathrm{R} \$ 1,98$ & $\mathrm{R} \$ 2,11$ & $\mathrm{R} \$ 2,25$ \\
\hline Perdas pelo uso da embalagem (R\$/caminhão truck) & $\mathrm{R} \$ 0.00$ & $\mathrm{R} \$ 0.00$ & $\mathrm{R} \$ 0.00$ & $\mathrm{R} \$ 0.00$ & $\mathrm{R} \$ 0.00$ \\
\hline Total das despesas (R\$/caminhão truck) & $\mathrm{R} \$ 5.505 .52$ & $\mathrm{R} \$ 5.606 .15$ & $\mathrm{R} \$ 5.706 .78$ & $\mathrm{R} \$ 5.807 .41$ & $\mathrm{R} \$ 5.908 .04$ \\
\hline Lucro (ou preiuízo) sem depreciacão (R\$/caminhão truck) & $(\mathrm{R} \$ 381.90)$ & $(\mathrm{R} \$ 287.80)$ & $(\mathrm{R} \$ 192.79)$ & $(\mathrm{R} \$ 98.69)$ & $(\mathrm{R} \$ 3.68)$ \\
\hline Depreciação 8anos (R\$/caminhão truck) & $(\mathrm{R} \$ 115.27)$ & (R\$ 115.27) & (RS 115.27) & $(\mathrm{R} \$ 115.27)$ & (R\$ 115.27) \\
\hline Lucro (ou prejuízo) líquido ( $\mathrm{R} \$ /$ caminhão truck) & $(\mathrm{R} \$ 497.17)$ & (R\$ 403.08) & (R\$308.06) & $(\mathrm{R} \$ 213.97)$ & $(\mathrm{R} \$ 118.95)$ \\
\hline Valor do quilo de laranja destinada ao cliente, sem depreciação ( $\mathrm{R} \$ / \mathrm{kg}$ ) & $\mathrm{R} \$ 0,60$ & $\mathrm{R} \$ 0,59$ & $\mathrm{R} \$ 0,57$ & $\mathrm{R} \$ 0,56$ & $\mathrm{R} \$ 0,55$ \\
\hline Valor do quilo de laranja destinada ao cliente, com depreciação $(\mathrm{R} \$ / \mathrm{kg})$ & $\mathrm{R} \$ 0,62$ & $\mathrm{R} \$ 0,60$ & $\mathrm{R} \$ 0,59$ & $\mathrm{R} \$ 0,57$ & $\mathrm{R} \$ 0,56$ \\
\hline Valor de venda $(\mathrm{R} \$ / \mathrm{kg})$ & $\mathrm{R} \$ 0,55$ & $\mathrm{R} \$ 0,55$ & $\mathrm{R} \$ 0,55$ & $\mathrm{R} \$ 0,55$ & $\mathrm{R} \$ 0,55$ \\
\hline Lucro (prejuízo), sem depreciação (\%) & $(8,39) \%$ & $(6,01) \%$ & $(3,84) \%$ & $(1,87) \%$ & $(0,07) \%$ \\
\hline Lucro (nreiúzo) com depreciacão (\%) & $(1065) \%$ & $(822) \%$ & $(5,09) \%$ & $(398) \%$ & $(2,2) \%$ \\
\hline
\end{tabular}

Fonte: Fazendas Reunidas Raio de Sol, op. cit., p.50 e dados de pesquisa. 
Para as simulações de avaliação de uso dos demais tipos de embalagens, foram realizadas mudanças em alguns valores de determinados itens da planilha, conforme descrito a seguir.

a) Uso de embalagem de madeira tipo "M": adotoutse o valor de $\mathrm{R} \$ 3,00$ referente ao preço da embalagem de madeira, e, neste mesmo item, considerourse o valor de 10 viagens de retorno da embalagem; o valor de $10 \%$ referente ao nível de perdas de embalagens retornáveis; o valor de $\mathrm{R} \$ 0,10$ para despesas com rótulos; o valor de $0,80 \%$ como sendo a taxa mensal da poupança (setembro de 2003) para o cálculo do custo de oportunidade de uso da referida embalagem; valores nulos para os itens "despesas com carregamento/descarregamento" na central do supermercado, "perdas pelo uso da embalagem" e "desconto financeiro".

b) Uso de embalagens plásticas compradas retornáveis: adotou-se o valor de R\$ 10,00 referente ao preço da embalagem de "plástico comprada", e, neste mesmo item, considerou-se o valor de 60 viagens de retorno da embalagem; o valor de $2 \%$ referente ao nível de perdas de embalagens retornáveis; o valor de $\mathrm{R} \$ 0,10$ por embalagem referente às despesas com rótulos; o valor de $0,80 \%$ como sendo a taxa mensal da poupança (setembro de 2003) para o cálculo do custo de oportunidade de uso da referida embalagem; valores nulos foram atribuídos aos itens "desconto financeiro", "despesas com carregamento/descarregamento" na central do supermercado e "perdas pelo uso da embalagem".

c) Uso de embalagem de papelão: adotourse o valor de $\mathrm{R} \$ 2,00$ referente ao preço da embalagem de papelão; o valor de $0,80 \%$ como sendo a taxa mensal da poupança (setembro de 2003) para o cálculo do custo de oportunidade de uso da referida embalagem; valores nulos para os itens: "desconto financeiro", "despesas com carregamento/descarregamento" na central do supermercado, "despesas com embalagens retornáveis perdidas", "despesas com rótulos" (uma vez que as informações do produtor poderão ser impressas na própria embalagem) e "perdas pelo uso da embalagem". 
Os resultados obtidos por meio das simulações adicionais (referentes ao uso dos demais tipos de embalagens) e os respectivos níveis porcentuais de lucro com depreciação para cada nível de refugo, para o produtor 3, de acordo com o cenário 1 , podem ser observados na Tabela 20.

Tabela 20. Nível porcentual de lucro com depreciação para os diferentes tipos de embalagens e respectivos sistemas, em diferentes níveis de refugo, referentes ao entrevistado “3”, cenário 1, 2003.

\begin{tabular}{lccccc}
\hline \multicolumn{1}{c}{ Embalagens } & \multicolumn{5}{c}{ Níveis de Refugo } \\
& $35 \%$ & $30 \%$ & $25 \%$ & $20 \%$ & $15 \%$ \\
\hline Plástica (comprada retornável) & 6,89 & 10,39 & 13,62 & 16,57 & 19,33 \\
Madeira (retornável) & 5,74 & 9,16 & 12,33 & 15,21 & 17,90 \\
Plástica (aluguel) & $(10,65)$ & $(8,22)$ & $(5,99)$ & $(3,98)$ & $(2,12)$ \\
Papelão (descartável) & $(10,72)$ & $(8,30)$ & $(6,08)$ & $(4,07)$ & $(2,21)$ \\
\hline
\end{tabular}

Fonte: dados de pesquisa.

O cenário 1, conforme já relatado, caracteriza-se por apresentar a opção do cliente estar vendendo laranjas de variedade Pêra para supermercados pertencentes a grandes redes utilizando-se embalagem plástica sob o sistema de aluguel (com taxa de desconto financeiro equivalente a $15 \%$ e valor do aluguel correspondente a $R \$ 4,50$ ) e ainda apresentar as opções do cliente estar vendendo suas frutas para outros clientes, como atacadistas, CEAGESP ou CEASAs, utilizando-se embalagens de "plástico compradas", de madeira "M" e de papelão. Cabe salientar que, nesse estudo de caso, o uso da embalagem de plástico sob sistema de aluguel para supermercado pertencente a uma grande rede é um caso real e não uma simulação. Assim, sob as considerações dessa análise, tem-se que não está sendo viável para o entrevistado “3” vender laranjas para um supermercado de grande rede em nenhum nível de refugo, ou seja, não está sendo viável utilizar a embalagem de plástico sob o sistema de aluguel sob as condições de taxa de desconto financeiro de $15 \%$ e aluguel equivalente a $\mathrm{R} \$ 4,50$. Observa-se que 
seria mais viável para o entrevistado " 3 ”, ainda nesse cenário, vender suas laranjas para outros tipos de clientes, como atacadistas, CEASAs ou CEAGESP e, assim sendo, seria mais viável para utilizar-se da embalagem plástica comprada, em qualquer nível de refugo. Como segunda alternativa, o produtor poderia vender laranjas para atacadistas ou CEASAs utilizando-se embalagens de madeira "M", em qualquer nível de refugo. Como terceira opção, não recomendada por apresentar prejuízos em qualquer nível de refugo, seria a de utilizar a embalagem de plástico sob o sistema de aluguel para vender suas frutas aos clientes atacadistas ou CEASAs. No entanto, seria menos onerosa se comparada à opção de venda de frutas a clientes como atacadistas ou CEASAs, utilizando-se embalagem de papelão.

Considerando-se o cenário 2 , tem-se que o produtor poderia vender suas frutas a supermercados pertencentes às pequenas redes (com taxa de desconto financeiro de 3,5\% e aluguel equivalente a $\mathrm{R} \$ 2,10$ ) ou vendê-las para outros clientes, como atacadistas, CEASAs ou CEAGESP, utilizando-se embalagens de "plástico compradas", de papelão, ou de madeira "M". Assim, por meio da Tabela 21, sob as considerações do cenário 2, têm-se os valores porcentuais de lucro com depreciação para cada tipo de embalagem. 
Tabela 21. Nível porcentual de lucro com depreciação para os diferentes tipos de embalagens e respectivos sistemas, em diferentes níveis de refugo, referentes ao entrevistado “3”, cenário 2, 2003.

\begin{tabular}{lccccc}
\hline \multicolumn{1}{c}{ Embalagens } & \multicolumn{5}{c}{ Níveis de Refugo } \\
& $35 \%$ & $30 \%$ & $25 \%$ & $20 \%$ & $15 \%$ \\
\hline Plástica (comprada retornável) & 6,89 & 10,39 & 13,62 & 16,57 & 19,33 \\
Madeira (retornável) & 5,74 & 9,16 & 12,33 & 15,21 & 17,90 \\
Plástica (aluguel) & 2,39 & 5,59 & 8,55 & 11,24 & 13,75 \\
Papelão (descartável) & $(10,72)$ & $(8,30)$ & $(6,08)$ & $(4,07)$ & $(2,21)$ \\
\hline
\end{tabular}

Fonte: dados de pesquisa.

Por meio dos valores de lucro com depreciação da Tabela 21, observa-se que prevalece, no cenário 2, a alternativa de vender frutas para clientes como atacadistas ou CEASAs utilizando-se embalagem "plástica comprada", e secundariamente a embalagem de madeira "M", ambas para qualquer nível de refugo. No entanto, a terceira opção passa a ser a de vender laranjas para supermercados pertencentes às pequenas redes, a partir da utilização de embalagens de plástico sob o sistema de aluguel em qualquer nível de refugo. Além disso, tem-se a alternativa de vender frutas para atacadistas ou CEASAs utilizando-se a embalagem de papelão, que, além de ser a menos viável para o cenário 2, não é recomendada por apresentar prejuízos em todos os níveis de refugo.

O cenário 3 apresenta as alternativas de uso de todos os tipos de embalagens quando o cliente se refere a supermercados pertencentes às pequenas redes (com taxa de desconto financeiro de 3,5\% e aluguel equivalente a $\mathrm{R} \$ 2,10$ ). Os resultados observados constam na Tabela 22. Observa-se que, se o produtor insistir em vender suas frutas somente a supermercados pertencentes às pequenas redes, a opção mais viável é a de utilizar a embalagem "plástica comprada", em qualquer nível de refugo. Como segunda alternativa, o produtor poderia estar utilizando a embalagem de plástico sob o sistema de aluguel e, como terceira opção, ele poderia estar utilizando a embalagem de madeira 
“M”, ambas em qualquer nível de refugo. Já a utilização de embalagem de papelão não seria recomendada pois, além de ser a menos viável das alternativas, apresenta prejuízos de uso em todos os níveis de refugo.

Tabela 22. Nível porcentual de lucro com depreciação para os diferentes tipos de embalagens e respectivos sistemas, em diferentes níveis de refugo, referentes ao entrevistado "3”, cenário 3, 2003.

\begin{tabular}{lccccc}
\hline \multicolumn{1}{c}{ Embalagens } & \multicolumn{5}{c}{ Níveis de Refugo } \\
& $35 \%$ & $30 \%$ & $25 \%$ & $20 \%$ & $15 \%$ \\
\hline Plástica (comprada retornável) & 3,03 & 6,28 & 9,27 & 12,00 & 14,54 \\
Plástica (aluguel) & 2,39 & 5,59 & 8,55 & 11,24 & 13,75 \\
Madeira (retornável) & 1,97 & 5,15 & 8,08 & 10,75 & 13,23 \\
Papelão (descartável) & $(13,43)$ & $(11,15)$ & $(9,06)$ & $(7,18)$ & $(5,45)$ \\
\hline
\end{tabular}

Fonte: dados de pesquisa.

Para o estudo de caso relacionado ao produtor "3", não se consideraram as despesas referentes às perdas proporcionadas pela utilização de embalagens de papelão ( $2 \%$ da receita obtida com a venda de fruta ao cliente) e de madeira (10\% da receita obtida com a venda de fruta ao cliente), pois o cliente neste caso se localiza a uma distância de até $220 \mathrm{~km}$ a partir do Packing-House, sendo então essas despesas consideradas nulas.

\subsection{Considerações finais sobre os entrevistados}

A princípio não existe uma única melhor embalagem para a comercialização de laranja, e sim a melhor embalagem para cada produtor, conforme suas particularidades. A Tabela 23 mostra as embalagens e os respectivos sistemas mais viáveis de uso para cada produtor entrevistado para esta pesquisa, em cada situação ou cenário considerado. 
Tabela 23. Embalagens utilizadas ou recomendadas para cada produtor, 2003.

\begin{tabular}{llll}
\hline & Entrevistado 1 & Entrevistado 2 & Entrevistado 3 \\
\hline Cenário 1 & Plástica (comprada & Plástica (comprada & Plástica (comprada \\
& retornável) & retornável) & retornável) \\
Cenário 2 & Plástica (comprada & Plástica (comprada & Plástica (comprada \\
& retornável) & retornável) & retornável) \\
Cenário 3 & Plástica (comprada & Plástica (comprada & Plástica (comprada \\
& retornável) & retornável) & retornável) \\
Situação Atual & Madeira (retornável) & Papelão (descartável) & Plástica (aluguel) \\
\hline
\end{tabular}

Fonte: dados de pesquisa.

Nota-se que coincidentemente, a embalagem de "plástico comprada" apresentou-se como a mais viável de utilização para todos os entrevistados, em todos os cenários. Ainda nesse contexto, vale lembrar que, nos resultados obtidos para o entrevistado "2", estão consideradas as perdas proporcionadas pela utilização das embalagens de madeira "M" e de papelão.

Outra importante consideração refere-se à importância da planilha Fazendas Reunidas Raio de Sol, op. cit., p.50 não somente como instrumental de análise para obter qual embalagem é mais viável economicamente de uso para cada entrevistado, mas também como instrumental de formação do preço $(\mathrm{R} \$ / \mathrm{kg})$ da fruta a ser vendida ao cliente, de forma que o produtor venha a detectar a partir de que preço são notados lucros. Assim, por meio da Tabela 24 , observa-se o preço $(\mathrm{R} \$ / \mathrm{kg})$ pelo qual deveriam ser vendidas as laranjas, conforme o entrevistado, para que se observassem lucros, em todos os níveis de refugo, utilizando-se embalagens de papelão e de plástico sob o sistema de aluguel, nos três cenários considerados. 
Tabela 24. Preço do kg da fruta, nos cenários considerados, utilizando-se determinadas embalagens, para obtenção de um valor a partir do qual se obtêm valores de lucro com depreciação em todos os níveis de refugo, para cada entrevistado, 2003.

\begin{tabular}{clccc}
\hline Entrevistado & Embalagens & $\begin{array}{c}\text { Cenário 1 } \\
(\mathrm{R} \$ / \mathrm{kg})\end{array}$ & $\begin{array}{c}\text { Cenário 2 } \\
(\mathrm{R} \$ / \mathrm{kg})\end{array}$ & $\begin{array}{c}\text { Cenário 3 } \\
(\mathrm{R} \$ / \mathrm{kg})\end{array}$ \\
\hline 1 & Papelão (descartável) & 0,68 & 0,68 & 0,70 \\
1 & Plástico (alugada) & 0,70 & - & - \\
2 & Papelão (descartável) & - & - & 0,57 \\
3 & Papelão (descartável) & 0,62 & 0,62 & 0,65 \\
3 & Plástico (alugada) & 0,64 & - & - \\
\hline
\end{tabular}

Fonte: dados de pesquisa.

As embalagens de plástico sob o sistema de aluguel e de papelão foram as que não apresentaram níveis porcentuais de lucro com depreciação nos cenários considerados para o entrevistados. Assim, por meio da planilha Fazendas Reunidas Raio de Sol, op. cit., p.50, atribuíram-se valores no item "Total de fruta para cliente (R\$/caminhão truck)", até que se observasse um valor ( $\mathrm{R} \$ / \mathrm{kg}$ de fruta) a partir do qual se observariam valores de lucro para todos os níveis de refugo. Logo, obteve-se que, para o cenário 1, o produtor " 1 " deveria vender suas laranjas a um preço de $\mathrm{R} \$ 0,67 / \mathrm{kg}$ utilizando-se embalagens de papelão, ou a um preço de $\mathrm{R} \$ 0,70 / \mathrm{kg}$ utilizando-se embalagens plásticas sob o sistema de aluguel. Ainda sob esse cenário, o produtor "3" deveria vender suas laranjas a um preço de $\mathrm{R} \$ 0,62 / \mathrm{kg}$ utilizando-se embalagens de papelão, ou a um preço de $\mathrm{R} \$ 0,64 / \mathrm{kg}$, se utilizasse a embalagem de plástico sob o sistema de aluguel. Considerando-se o cenário 2, tem-se que o produtor "1" deveria vender suas frutas a um preço de $\mathrm{R} \$ 0,68 / \mathrm{kg}$ ao se utilizar embalagens de papelão, para obter lucro com depreciação em todos os níveis de refugo, ao passo que o produtor "3" deveria vender suas laranjas a $\mathrm{R} \$ 0,62 / \mathrm{kg}$, utilizando-se embalagem de papelão. Já no cenário 3, a partir da utilização de embalagens de papelão, tem-se que os produtores " 1 ", 
"2" e "3" deveriam vender suas frutas aos preços de $\mathrm{R} \$ 0,70 / \mathrm{kg}, \mathrm{R} \$ 0,57 / \mathrm{kg}$ e $\mathrm{R} \$$ 0,65/kg, respectivamente, para que obtivessem lucro com depreciação em todos os níveis de refugo considerados. 


\section{CONCLUSÕES}

Buscourse, com este trabalho, dentro do contexto de multicasos, a análise da viabilidade econômica da utilização de diferentes tipos de embalagens para laranja de mesa, a partir do estudo de três casos referentes a produtores localizados no Estado de São Paulo.

Conforme as análises realizadas sobre os dados específicos de cada produtor, por intermédio da planilha Fazendas Reunidas Raio de Sol, op. cit., p.50, pôde-se concluir qual a embalagem mais adequada economicamente para cada caso, considerando-se os eventuais níveis de perdas proporcionados pelo uso das embalagens de papelão e das embalagens de madeira tipo " $M$ ".

Nesse sentido, os resultados apresentados e analisados nesta dissertação permitem indicar que, genericamente, não existe uma única embalagem mais viável economicamente sob o ponto de vista de utilização. O que realmente se pode afirmar é que há a embalagem mais viável economicamente para cada caso (ou produtor), dadas suas características específicas, como formas de negociações de frete com o cliente, pagamentos de taxas referentes ao transporte, níveis de perdas relativos ao uso de determinadas embalagens em distâncias longas, variações nos preços da fruta vendida ao cliente e à indústria, valores de preços referentes ao custo de beneficiamento, variações de custos referentes às embalagens utilizadas, despesas referentes à intermediação e variações de taxas relativas ao desconto financeiro (conforme o tipo de supermercado).

A partir dessas considerações, observou-se que a viabilidade de uso de cada tipo de embalagem está relacionada não somente ao tipo de embalagem, mas 
também ao sistema utilizado (aluguel, retornável ou descartável), o que pode implicar despesas equivalentes às embalagens retornáveis perdidas para os casos de uso de embalagens de madeira e de "plástico compradas".

Cabe também relatar que o tipo de cliente influencia a análise da embalagem mais viável para os estudos de caso considerados. Se o cliente corresponder a um supermercado, devem ser consideradas as despesas referentes à taxa de desconto financeiro. Se o cliente corresponder aos atacadistas, às CEASAs ou à CEAGESP, essa taxa será nula; porém, devem-se considerar despesas relativas às perdas de embalagens retornadas (para embalagens reutilizáveis), uma vez que esses clientes normalmente não apresentam condições logísticas adequadas para administração das caixas retornadas.

Dessa forma, para uma avaliação mais concreta da embalagem mais viável para cada caso estudado, optoutse pela consideração dos fatores "tipos de clientes", "tipos de embalagens" e "tipos de sistemas" utilizados por produtor entrevistado, sob os níveis de refugo de $15 \%, 20 \%, 25 \%, 30 \%$ e $35 \%$, em três cenários diferentes.

O entrevistado " 1 " se caracterizou pelo fato de vender as laranjas em caixas de madeira "M" destinadas às CEASAs e à CEAGESP. A partir da análise dos dados específicos desse produtor, observou-se que a embalagem de "plástico comprada" apresentou-se como a mais viável economicamente sob o ponto de vista de utilização nos três cenários considerados, para todos os níveis de refugo. Isso significa que, no primeiro cenário, esse produtor deveria vender suas laranjas a atacadistas ou às CEASAs, preferencialmente, utilizando-se de embalagens de "plástico compradas", em vez de vendê-las aos clientes, supermercadistas pertencentes às grandes redes (que apresentam taxas de desconto financeiro de $15 \%$ e exigem o uso de embalagens de plástico sob o sistema de aluguel). No segundo cenário também se verificou maior viabilidade se o produtor utilizasse embalagem de "plástico comprada" para clientes dos tipos atacadista ou CEASAs em vez de clientes supermercadistas; porém, nesse cenário os clientes supermercadistas são pertencentes às pequenas redes (que apresentam taxa de desconto financeiro equivalente a 3,5\% e não exigem necessariamente o uso da embalagem plástica sob o sistema de aluguel). Mesmo no terceiro cenário, em que 
apenas se considerou que o cliente corresponde a um supermercado pertencente a uma pequena rede, foi encontrada maior viabilidade econômica ao utilizar a embalagem de plástico comprada.

O entrevistado "2" se destacou por vender suas frutas em embalagens de papelão a mercados distantes (localizados na região Nordeste), sendo de responsabilidade do cliente as despesas relativas ao frete correspondente a esse percurso. Nesse caso, qualquer um dos tipos de embalagens considerados neste estudo apresentout se economicamente viável, sendo a embalagem de plástico comprada a mais viável em todos os cenários e em todos os níveis porcentuais de refugo. Isso significa que, no primeiro cenário, esse produtor deveria vender suas laranjas a clientes como atacadistas ou CEASAs, preferencialmente utilizando-se embalagens de "plástico compradas", em vez de vendê-las aos clientes supermercadistas pertencentes às grandes redes, utilizandose embalagens de plástico sob o sistema de aluguel. No segundo cenário também se notou maior viabilidade se o produtor utilizasse embalagem de "plástico comprada" para clientes do tipo atacadista ou CEASAs em vez de dientes supermercadistas pertencentes às pequenas redes. Já no terceiro cenário, em que apenas se considerou que o cliente corresponde a um supermercado pertencente a uma pequena rede, foi também encontrada maior viabilidade econômica ao utilizar a embalagem de "plástico comprada”. Além disso, o cliente desse entrevistado localiza-se a uma distância de 1.970 km a partir do Packing-House, o que demandou a consideração de perdas proporcionadas pelo uso de embalagens de papelão (em função da má ventilação interna) e de madeira (em função da falta de estabilidade de pilha e abrasão aos frutos).

O entrevistado "3" apresentourse como usuário da embalagem de plástico sob o sistema de aluguel e fornecendo a supermercado pertencente ao grupo Pão-deAçúcar (considerado como grande rede supermercadista). A partir das simulações conduzidas, observou-se que a embalagem de "plástico comprada" apresentoutse como a mais viável economicamente, sob o ponto de vista de utilização nos três cenários considerados e em todos os níveis de refugo em questão. Isso implica que, no primeiro cenário, é mais viável vender suas laranjas para clientes como atacadistas ou CEASAs 
utilizando-se embalagens de "plástico compradas" em vez de vendê-las aos supermercados pertencentes às grandes redes. No segundo cenário também se verificou maior vantagem econômica utilizando-se embalagem de "plástico comprada" quando o cliente foi considerado um atacadista ou CEASA, em vez de um supermercado pertencente a uma pequena rede. Da mesma forma, para o cenário 3, a embalagem de "plástico comprada" também foi apresentada como a mais viável embora nesse cenário o cliente considerado fosse apenas um supermercado pertencente a uma pequena rede (que admite o uso de outras embalagens, não necessariamente sob o sistema de aluguel).

Além dessas conclusões obtidas em cada estudo de caso, observourse que o valor do frete a partir do Packing-House até o cliente pode apresentar significativa participação no total de despesas, e que, se esse valor for repassado aos clientes, o produtor pode apresentar o privilégio de utilizar qualquer um dos tipos de embalagens (e respectivos sistemas) sem apresentar prejuízos na venda de suas frutas, conforme pôde ser observado no caso do entrevistado 2. No entanto, deve-se estar atento aos demais tipos de despesas já mencionados e também por qual valor o produtor estará vendendo suas frutas aos clientes e à indústria.

Diante desses fatores, a planilha Fazendas Reunidas Raio de Sol, op. cit., p.50, adotada neste trabalho, também permitirá estabelecer qual o valor mínimo equivalente ao preço da fruta $(\mathrm{R} \$ / \mathrm{kg})$ a ser vendida, não necessariamente laranja, podendo ser aplicada a outras frutas, específico às características de cada produtor e a cada tipo de embalagem utilizada. Isso permitiria o produtor observar em sua atividade de comercialização lucros com depreciação em todos os níveis de refugo.

Nesse sentido, observou-se que, se o entrevistado "1", sob o cenário 1, desejasse utilizar as embalagens de papelão e de plástico sob o sistema de duguel, que até então representaram prejuízos, deveria vender suas laranjas ao preço mínimo de $\mathrm{R} \$$ $0,68 / \mathrm{kg}$ e ao preço de $\mathrm{R} \$ 0,70 / \mathrm{kg}$, respectivamente, para observar lucro em todos os níveis de refugo, contrariando a opção inicialmente estabelecida (que corresponde ao uso da embalagem de "plástico comprada" como a mais viável para o cenário 1). Para o cenário 2, ele deveria vender suas frutas ao preço de $\mathrm{R} \$ 0,68 / \mathrm{kg}$ utilizando-se a 
embalagem de papelão, para obter lucro em todos os níveis de refugo, se desejasse contrariar a opção estabelecida inicialmente ("plástico comprada”). Já para o cenário 3, esse produtor deveria vender a laranja ao preço de $\mathrm{R} \$ 0,70 / \mathrm{kg}$, se desejasse utilizar a embalagem de papelão, contrariando a opção indicada inicialmente ("plástico comprada"), para obter um lucro em todos os níveis de refugo considerados.

No caso do entrevistado "2", somente seria observado prejuízo se fosse utilizada a embalagem de papelão, no cenário 3, para o nível de refugo equivalente a $35 \%$. Se mesmo assim fosse feita a opção de uso dessa embalagem nesse cenário, contrariando o tipo indicado inicialmente ("plástico comprada"), seriam observados valores de lucro em todos os níveis de refugo considerado, se o produtor vendesse sua laranja ao preço de $\mathrm{R} \$ 0,57 / \mathrm{kg}$.

Para o entrevistado " 3 ", observou-se, durante a análise dos resultados, que o uso da embalagem de papelão e de plástico sob o sistema de aluguel apresentou prejuízos de utilização, em todos os níveis de refugo no cenário 1. Se mesmo assim esse entrevistado desejasse utilizar as embalagens de papelão e de plástico sob o sistema de aluguel, contrariando a embalagem inicialmente indicada como a mais viável ("plástico comprada"), ele deveria vender suas laranjas por $\mathrm{R} \$ 0,62 / \mathrm{kg}$ e $\mathrm{R} \$ 0,64 / \mathrm{kg}$, respectivamente, para obter lucro em todos os níveis de refugo. No cenário 2, observour se que apenas o uso da embalagem de papelão apresentou prejuízos de utilização. Se o entrevistado 3 insistisse na utilização dessa embalagem nesse cenário, contrariando a inicialmente estabelecida como a mais viável para esse cenário ("plástico comprada"), ele deveria vender sua fruta por $\mathrm{R} \$ 0,62 / \mathrm{kg}$ para que obtivesse lucro em todos os níveis de refugo. Observou-se também no cenário 3 que o uso da embalagem de papelão foi a única alternativa que apresentou prejuízos de utilização. Assim, se esse produtor ainda desejasse utilizar essa embalagem, contrariando a opção iniciamente apresentada como a mais viável ("plástico comprada"), ele deveria vender o quilo da laranja por $\mathrm{R} \$ 0,65$, para obter o lucro em todos os níveis de refugo considerados.

Dessa forma, a planilha Fazendas Reunidas Raio de Sol, op. cit., p.50, até então não documentada na literatura, a partir deste estudo de multicasos, passa a ser 
formalmente reconhecida, permitindo a sua utilização para pesquisas acadêmicas e para pesquisas de ordem prática por parte de produtores de frutas, não obrigatoriamente de laranja. A partir disso, os produtores poderiam estar avaliando qual embalagem seria a mais viável economicamente para sua estrutura, permitindo também o estabelecimento do melhor preço da fruta para ser vendida ao cliente (e eventualmente à indústria), quando desejasse utilizar outras embalagens alternativas às inicialmente estabelecidas como as mais viáveis, dentro de cada cenário, observando lucros em todos os níveis de refugo. Provavelmente, a embalagem mais viável ao produtor poderia conferir um preço ao produto final mais viável ao consumidor.

Outras considerações importantes foram observadas durante as entrevistas realizadas a campo para coleta de dados específicos de cada produtor. Os três entrevistados acreditam que, uma vez beneficiadas, as laranjas dificilmente sofrerão perdas pelo uso da embalagem, pois receberam tratamentos que lhe conferem resistência. No entanto, quando a distância percorrida a partir da unidade de beneficiamento até o cliente for superior a $1.000 \mathrm{~km}$, perdas em laranjas (mesmo beneficiadas) por utilização de embalagens de papelão e de madeira " $M$ " poderão ser da ordem de $2 \%$ e $10 \%$, respectivamente. Para o caso da embalagem de papelão, essas perdas são provenientes da má ventilação interna da caixa e da absorção de umidade, reduzindo a resistência da embalagem, esmagando os frutos. Para o caso da embalagem de madeira, as perdas se referem à abrasão proporcionada pela superfície não laminada da madeira e à falta de estabilidade de pilha, pelo fato de essas embalagens não apresentarem medidas paletizáveis, desarranjando-se durante o percurso, principalmente em estradas com péssimas condições. Cabe ressaltar que esses níveis de perdas são também assim mensurados por instituições de pesquisas como o Instituto de Pesquisas Tecnológicas (IPT) e pela CEAGESP, por meio de trabalhos desenvolvidos pelo Centro de Qualidade em Horticultura $(\mathrm{CQH})$.

Ainda por intermédio das visitas realizadas, percebeu-se que os produtores defendem a embalagem que atualmente utilizam como a mais viável, embora não possuam um instrumental de análise tal como a planilha Fazendas Reunidas Raio de Sol, 
op. cit., p.50. Além disso, embora alguns utilizem embalagens retornáveis, tem-se observado o desejo dos produtores em repassar a responsabilidade de administração de caixas para o cliente. Casos de outros produtores foram citados pelos entrevistados em que o cliente leva as embalagens vazias até o produtor e este apenas as carrega com as frutas vendidas, minimizando despesas referentes à utilização e administração das embalagens. A avaliação da viabilidade desse sistema citado também seria possível de ser analisada por meio da utilização da planilha Fazendas Reunidas Raio de Sol, op. cit., p.50, considerando-se como nulas as despesas referentes às embalagens utilizadas.

Deve-se evidenciar que o estudo da viabilidade econômica de utilização de diferentes tipos de embalagem para cada caso específico requer a consideração conjunta das perdas proporcionadas pelo uso de determinadas embalagens em longas distâncias e dos custos envolvidos com a utilização das mesmas. Se forem consideradas apenas as perdas proporcionadas pelo uso de embalagens, pode-se correr o risco de utilizar embalagens muito caras, conferindo um alto valor ao preço final do produto. Se forem consideradas apenas embalagens mais viáveis financeiramente, pode-se estar utilizando embalagens que não preservam a qualidade do fruto, não atendendo às exigências do consumidor, além de contribuir para o aumento do volume de frutas estragadas e desperdiçadas.

É importante ressaltar que o nível de perdas durante o transporte, principalmente em função do uso de diferentes embalagens, é uma questão muito discutida, por não se observarem pesquisas capazes de evidenciar esse fator de maneira precisa e concreta.

Com relação à legislação específica, a aprovação da Portaria 62, as embalagens para laranja, assim como para outras frutas e legumes em geral, deverão ser paletizáveis, higienizadas e rotuladas.

Nesse sentido, novas embalagens vêm sendo desenvolvidas por pesquisadores de diversas instituições (o Instituto de Pesquisas Tecnológicas, por exemplo, vem desenvolvendo embalagens de madeira laminada para laranjas, paletizáveis e passíveis de higienização). Isso confere às embalagens maior 
responsabilidade com relação à fruta, pois deverão, além de embalar e proteger o conteúdo, preservar a qualidade, de modo que as características da fruta sejam compatíveis às apresentadas no rótulo, quando chegarem ao destino final. Aliados a isso, estudos e pesquisas podem ser desenvolvidos por meio da planilha Fazendas Reunidas Raio de Sol, op. cit., p.50, para cada nova embalagem, a fim de avaliar a viabilidade de uso das mesmas, conjuntamente às eventuais perdas proporcionadas por elas.

Em termos de trabalhos futuros correlatos, pesquisas de avaliação da viabilidade econômica do uso de embalagens para outras frutas e até mesmo para legumes e flores no mercado interno brasileiro são recomendadas. Em paralelo, a planilha Fazendas Reunidas Raio de Sol, op. cit., p.50 pode vir a se configurar como instrumental metodológico de ampla aplicação para esses estudos. Outra recomendação diz respeito às avaliações de viabilidade econômica de utilização de embalagens de frutas destinadas à exportação, podendo-se considerar despesas relativas às exigências de medidas técnicas e sanitárias impostas pelos diferentes mercados internacionais, proporcionando maior competitividade e qualidade de produtos brasileiros no mercado externo. 


\section{REFERÊNCIAS BIBLIOGRÁFICAS}

ABPO: a força do papelão ondulado. Circuito Agrícola, n.36, p.14-15, maio 1996a.

ABPO participa de estudos para padronização de embalagens. Circuito Agrícola, n.37, p.16-17, jun. 1996b.

A LOGÍSTICA na cadeia de hortifrutícolas: a oportunidade da embalagem de papelão ondulado. Valinhos: Rigesa Papel, Celulose e Embalagens Ltda, 2001. 49p.

BALLOU, R.H. Gerenciamento da cadeia de suprimentos: planejamento, organização e logística empresarial. Porto Alegre: Bookman, 2001. 532p.

BANZATO, J.M. A integração das embalagens dentro do sistema logístico. http://www.guiadelogistica.com.br (01 maio 2001a)

BANZATO, J.M. A reciclagem das embalagens. http://www.guiadelogistica.com.br (01 maio 2001b)

BANZATO, J.M.; MOURA, R.A. Embalagem, unitização e conteinerização. 2.ed. São Paulo: IMAM, 1997. v.3. 354p.

BENZI, L.D. Embalagens adequadas evitam perdas no setor agrícola. Revista Tecnologística, v.3, n.26, p.22-26, jan. 1998a.

BENZI, L.D. Papelão garante posição no mercado. Revista Tecnologística, v.3, n.27, p.20-25, fev. 1998b.

BRASIL. Leis, decretos, etc. Decreto $\mathrm{n}^{\circ} 4130$ de 13 de fevereiro de 2002. Diário Oficial, 14 fev. 2002. Seção 1. Alíquotas.

CABRAL, A.C.D.; MADI, L.F.C.; SOLER, R.M.; ORTIZ, S.A. Embalagens de produtos alimentícios. Campinas: ITAL, CETEA, 1983. 338p. 
CAIXAS de madeira: embalagem natural e sustentável. Revi Pack, p.31, 2000. http://www.ital.org.br/Tecnologia_de_Embalagem/tecnologia_de_embalagem.html (25 out. 2003)

CAIXETA FILHO, J.V. A modelagem de perdas no transporte de produtos agrícolas. Piracicaba, 1995. 112p. Tese (Livre-Docência) - Escola Superior de Agricultura “Luiz de Queiroz”, Universidade de São Paulo.

CAMPOS, H.C.M.; NANTES, J.F.D. Embalagens convenientes: uma estratégia na diferenciação de produtos. http://www.gepai.dep.ufscar.br/gepai22.pdf (29 out. 2003)

CHITARRA, M.I.F. Embalagem e transporte de frutos. Informe Agropecuário, v.17, n.179, p.19-27, 1994.

CONTROLLING product damage in distrubuition. http://www.nfpafood.org/documents/May2003UnsaleablesBro15.pdf (23 Oct. 2003)

CORTEZ, L.A.B.; BRAUNBECK, O.A.; CASTRO, L.R.; FUNES, R.; CARDOSO, J.L. Sistemas de colheita para frutas e hortaliças: oportunidade para semimecanizados. Revista Frutas \& Legumes, v. 2, n.13, p.12-15, mar./abr. 2002.

FIGUEIREDO, N.M.S.; MADI, L.F.C.; VIEIRA, L.F.; SANT'ANA, L.A.R. Estudo comparativo do custo de embalagens de madeira e de papelão para a comercialização de tomate. Campinas, jan./fev. 1978. p.187-207. (ITAL. Boletim do Instituto de Tecnologia de Alimentos, 55)

GARCIA, J.L. Comércio de frutas na Europa. http://www.embrapa.br (22 abr. 2001)

GONÇALVES, J.S.; SOUZA, S.A.M. Produção e comercialização de laranja de mesa no Estado de São Paulo. Laranja, v.15, n.2, p.35-84, 1994.

GORENSTEIN, R. Comercialização: depois da colheita mais cuidados. Agrianual 2000. Anuário da Agricultura Brasileira, p.24-26, 2000.

GUTIERREZ, A.S.D. A mágica da embalagem São Paulo: CEAGESP, CQH, 2001. $11 \mathrm{p}$. 
HARDER, W.C. Normas de classificação e seus impactos na coordenação do sistema agroindustrial da laranja de mesa. Piracicaba, 1998. 75p. Monografia (Graduação) Escola Superior de Agricultura "Luiz de Queiroz”, Universidade de São Paulo.

IVANCKO, S.B. Escolha de embalagens para frutas e verduras. Agrianual 2002. Anuário da Agricultura Brasileira, p.40, 2002.

KOTLER, P. Administração de linhas de produtos, marcas e embalagens. In: KOTLER,

P. Administração de marketing: análise, planejamento, implementação e controle. São Paulo: Atlas, 1998. cap.15, p.382-411.

LEDERMANN, J.; YOUNT, L. Quantifying packaging waste at grocery stores. Resource Recycling, v.11, n.12, p.43-44, Dec. 1992.

MONER, J.B. El problemático futuro del embalaje en el sector hortofrutícola espanol. Fruticultura Profesional, n.52, p.61-62, ener./feb. 1993.

MOURA, R.A. Sistemas e técnicas de movimentação e armazenagem de materiais. 4.ed. São Paulo: IMAM, 1998. v.1. 452p.

MURARO, R.P.; WARDOWSKI, W.F. Estimated cost of packing florida citrus, 1990-91 season. Gainesville: University of Florida, Food and Resourse Economics Departament, Sep. 1992. 16p. (Economic Information Report, EI 92-7)

NADAY, M.J. Colheita, beneficiamento e embalagem dos citrus. In: MENTEN, J.O.M.; DOURADO-NETO, D.; TORRADO, P.V. Curso intensivo de citricultura. Piracicaba: ESALQ, A.E.C. Ceres, 1991. p.185-194.

OLIVEIRA, C.L.; NEVES, M.F.; SCARE, R.F. Embalagens para alimentos com enfoque em marketing: projetos e tendências. In: NEVES, M.F.; CASTRO, L.T. Marketing e estratégia em agronegócios e alimentos. São Paulo: Atlas, 2003. cap.7, p.147-161.

ONDE estão os parceiros logísticos para o projeto de banco de caixas? Revista Tecnologística, v.6, n.74, p.34-40, jan. 2002. 
PICHLER, E.F. Estudo de padronização de caixas para hortícolas. São Paulo: IPT, Divisão de Tecnologia de Transportes, Laboratório de Embalagens e Acondicionamento (LEA), 2001a. 19p. (Relatório Técnico, 53275)

PICHLER, E.F. Estudo de padronização de caixas para hortícolas. São Paulo: IPT, Divisão de Tecnologia de Transportes, Laboratório de Embalagens e Acondicionamento (LEA), 2001b. 22p. (Relatório Técnico, 56230)

PIOVESAN, M. Embalagem: segredo do bom negócio. Toda Fruta, v.2, n.11, p.20-24, 1987.

RAMOS, S.Y. Avaliação da localização de Packing-Houses no Estado de São Paulo: o caso da laranja de mesa. Piracicaba, 2001. 132p. Dissertação (Mestrado) - Escola Superior de Agricultura “Luiz de Queiroz”, Universidade de São Paulo.

RECICLAGEM no Brasil. http://www.abre.org.br (28 abr. 2002)

RIGESA. Produtos: frutas, flores e legumes: Plaform. http://www.rigesa.com.br/ produtos/frutas_plaform.jsp. (28 abr. 2002a)

RIGESA. Marcas e símbolos . http://www.rigesa.com.br/dicas. (28 abr. 2002b)

RIGESA. Impressão de embalagens em papelão ondulado I. http://www.rigesa.com.br/dicas/dica_01.jsp?tipld=52. (28 abr. 2002c)

ROSENBLOOM, B. Canais de marketing: uma visão gerencial. São Paulo: Atlas, 2002. 557p.

ROSS, S.A.; JAFFE, J.F.; WESTERFIELD, R.W. Valor presente líquido e orçamento de capital. In: ROSS, S.A.; JAFFE, J.F.; WESTERFIELD, R.W. Administração financeira. São Paulo: Atlas, 2002. cap.7, p.147-170.

ROY, S.K.; PAL, R.K. Multilocational studies to reduce post harvest losses during harvesting, handling, packaging, transportation and marketing of mango in Índia. Acta Horticulturae, n.291, p.499-507, June 1991. http://www.actahort.org/books/ 291/291_57.htm (29 Oct. 2003) 
SCHUUR, C.C.M. Packaging for fruits, vegetables and root crops. Bridgetown: FAO, Sep. 1988. 11p.

SERAGINI, L. Gestão estratégica da embalagem. In: SARANTÓPOULOS, C.I.G.L.; ORTIZ, S.A.; MADI, L.F.C. Brasil pack trends 2005: embalagem, distribuição e consumo. Campinas: ITAL, CETEA, 2000. p.243-263.

SERAGINI, L. Design, marcas e embalagem Ribeirão Preto: Universidade de São Paulo, 2002. 41p. (MBA Marketing FUNDACE)

SERAGINI, L. Design como estratégia empresarial. http://www.idea.org.br/programas/ 07.htm (08 set. 2003)

SETOR de embalagem: informações gerais sobre o setor de embalagem. http://www.spdesign.sp.gov.br/embala/embala3.htm (26 set. 2003)

SHEPHERD, A.W. A guide marketing costs and how to calculate them. Rome: FAO, Agricultural Support System Division, Marketing and Rural Finace Service, 1993. $23 \mathrm{p}$.

SILVA, M.L.M. Fruticultura: o fim da reforma das caixas. Agrianual 1999. Anuário da agricultura brasileira, p.34, 1999.

TRIVIÑOS, N.S. Introdução à pesquisa em ciências sociais: a pesquisa qualitativa em educação. São Paulo: Atlas, 1992. 175p.

YIN, R.K. Estudo de caso: planejamento e métodos. Porto Alegre: Bookman, 2001. $205 \mathrm{p}$. 
APÊNDICE 
APÊNDICE 1 - Instrução Normativa instituída em Novembro de 2002.

\section{MINISTÉRIO DA AGRICULTURA, PECUÁRIA E ABASTECIMENTO SECRETARIA DE APOIO RURAL E COOPERATIVISMO}

\section{INSTRUÇÃO NORMATIVA CONJUNTA SARC / ANVISA / INMETRO № 009, DE 12 DE NOVEMBRO DE 2002.}

O SECRETÁRIO DE APOIO RURAL E COOPERATIVISMO, DO MINISTÉRIO DA AGRICULTURA, PECUÁRIA E ABASTECIMENTO, O DIRETOR-PRESIDENTE DA AGÊNCIA NACIONAL DE VIGILÂNCIA SANITÁRIA, DO MINISTÉRIO DA SAÚDE, E O PRESIDENTE DO INSTITUTO NACIONAL DE METROLOGIA, NORMALIZAÇÃO E QUALIDADE INDUSTRIAL, DO MINISTÉRIO DO DESENVOLVIMENTO, INDÚSTRIA E COMÉRCIO EXTERIOR, no uso de suas respectivas atribuições legais, tendo em vista o disposto na Lei no 9.972, de 25 de maio de 2000, na Lei \& 9.782, de 26 de janeiro de 1999, na Lei if 8.080, de 19 de setembro de 1990, na Lei if 9.933, de 20 de dezembro de 1999,

Considerando a necessidade de regulamentar o acondicionamento, manuseio e comercialização dos produtos hortícolas "in natura" em embalagens próprias para a comercialização, visando à proteção, conservação e integridade dos mesmos;

Considerando a necessidade de assegurar a verificação das informações a respeito da classificação dos produtos hortícolas;

Considerando a necessidade de assegurar a obrigatoriedade da indicação qualitativa e quantitativa, da uniformidade dessas indicações e do critério para a verificação do conteúdo líquido, e o que consta do Processo if 21000.007895/2000-91, resolvem:

Art. 1ำ As embalagens destinadas ao acondicionamento de produtos hortícolas "in natura" devem atender, sem prejuízo das exigências dispostas nas demais legislações específicas, aos seguintes requisitos:

I - as dimensões externas devem permitir empilhamento, preferencialmente, em palete ("pallet") com medidas de 1,00 m (um metro) por 1,20 m (um metro e vinte centímetros);

II - devem ser mantidas íntegras e higienizadas;

III - podem ser descartáveis ou retornáveis; as retornáveis devem ser resistentes ao manuseio a que se destinam, às operações de higienização e não devem se constituir em veículos de contaminação; 
IV - devem estar de acordo com as disposições específicas referentes às Boas Práticas de Fabricação, ao uso apropriado e às normas higiênico-sanitárias relativas a alimentos;

V - as informações obrigatórias de marcação ou rotulagem, referentes às indicações quantitativas, qualitativas e a outras exigidas para o produto devem estar de acordo com as legislações específicas estabelecidas pelos órgãos oficiais envolvidos.

Art. 2- Para efeito desta Instrução Normativa Conjunta, entende-se por produtos hortícolas as frutas e hortaliças "in natura", não processadas e colocadas à disposição para comercialização.

Art. 3o $\mathrm{O}$ fabricante ou o fornecedor de embalagens de produtos hortícolas deve estar identificado nas mesmas, constando no mínimo a sua razão social, o número do CNPJ e o endereço.

Parágrafo único. É de inteira responsabilidade do fabricante informar as condições apropriadas de uso, tais como o peso máximo e o empilhamento suportável, as condições de manuseio, bem como se a mesma é retornável ou descartável.

Art. 4o $\mathrm{O}$ cumprimento do disposto nesta Instrução Normativa Conjunta, no que diz respeito à verificação das informações relativas à classificação do produto, constantes dos rótulos das embalagens, é de competência do órgão técnico competente do Ministério da Agricultura, Pecuária e Abastecimento. A verificação do cumprimento dos aspectos higiênico-sanitários compete ao Ministério da Saúde, e ao Ministério do Desenvolvimento, Indústria e Comércio Exterior, por parte do INMETRO, aqueles atinentes à indicação quantitativa das embalagens.

Parágrafo único. As ações referidas neste artigo serão exercidas de forma não cumulativa e baseadas na legislação específica de cada órgão oficial envolvido, observadas as suas respectivas áreas de competência.

Art. 5o- Os casos omissos serão resolvidos pelos órgãos oficiais envolvidos, observadas suas respectivas áreas de competência.

Art. 6o Esta Instrução Normativa Conjunta entra em vigor em 180 (cento e oitenta) dias, a contar da data de sua publicação.

RINALDO JUNQUEIRA DE BARROS

Secretário da SARC/MAPA

GONZALO VECINA NETO

Diretor-presidente da ANVISA/MS

\author{
ARMANDO MARIANTE CARVALHO JÚNIOR \\ Presidente do INMETRO/MDIC
}


APÊNDICE 2 - Dados específicos do entrevistado "1".

Para carga de fruta correspondenete a um caminhão truck
com capacidade média para $12.040 \mathrm{~kg}$
Produtor: Entrevistado $1 \quad$ Data: $29 / 09 / 2003$

Dados iniciais

Valores

Preço da fruta vendida ao Cliente $(\mathrm{R} \$ / \mathrm{kg})$

Preço da fruta vendida para a Indústria ( $\mathrm{R} \$ /$ caixa de $40,8 \mathrm{~kg}$ )

Frete do caminhão para a Indústria ( $\mathrm{R}$ /caminhão truck)

Distância média da Fazenda até a Indústria $(\mathrm{km})$

Preço da caixa de 40,8kg de laranja vinda da produção até o Packing-House (R \$/caixa de 40,8 kg', 12,00

Despesa com colheita das frutas na Fazenda (R\$/caixa de 40,8 kg)

Frete do caminhão da Fazenda para o Packing-House (R \$/caminhão truck)

Distância média da Fazenda até o Packing-House $(\mathrm{km})$

\section{Embalagens}

Preço do aluguel da caixa plástica para supermercados (R $\$ /$ caixa de $20 \mathrm{~kg}$ ao mês)

Despesa com descarregamento na Central do Supermercado (R $\$ /$ caminhão truck)

Preço da caixa de Madeira "M" (R \$/caixa nova)

Durabilidade da caixa Madeira "M" (número de viagens)

Preço da caixa plástica comprada (R \$caixa nova de $27 \mathrm{~kg}$ )

Durabilidade da caixa plástica comprada (número de viagens)

Preço da caixa de Papelão (R $\$$ caixa nova de $18 \mathrm{~kg}$ )

Perda de caixas retornáveis Madeira (\%)

Perda de caixas retornáveis Plásticas (\%)

\section{Demais despesas}

Beneficiamento: seleção, higienização das caixas retornáveis, cola ou grampo para caixa de papelão $(\mathrm{R} \$ / \mathrm{kg})$

Intermediação: terceiros que vendem frutas do Packing-House aos Clientes

(\% do total vendido destinada aos terceiros)

$\begin{array}{ll}\text { Preço do tambor (para } 160000 \mathrm{~kg} \text { de fruta) de cera (R } \$ / \text { tambor) } & 750,00\end{array}$

$\begin{array}{ll}\text { Frete do Packing-House até cliente (R \$/caminhão truck) } & 300,00\end{array}$

Distância média do Packing-House até cliente $(\mathrm{km})$

Despesa: chapas, pedágio, refeição motorista e descarregamento no cliente (R $\$ /$ caminhão truck)

Despesa com ICMS sobre o frete (R \$/caminhão truck) ou \% do ICMS sobre o frete

Despesas bancárias: boletos bancários ( $\mathrm{R} \$$ caminhão truck)

Taxa do Funrural (\%)

Taxa de desconto financeiro (\% do total da carga de um caminhão vendida aos supermercados)

Estimativas de perdas de frutas proporcionadas pela utilização de cada embalagem

\section{(amassamento, má ventilação)}

Uso da caixa de Papelão (18 kg) em distâncias acima de $1000 \mathrm{~km}-(\%)$

Uso da caixa de Papelão (18 kg) em distâncias abaixo de $1000 \mathrm{~km}-(\%)$

Uso da caixa de Madeira tipo "M" comprada retornável (27 kg) em distâncias acima de $1000 \mathrm{~km}-(\%), \quad 10$

Uso da caixa de Madeira tipo "M" comprada retornável (27 kg) em distâncias abaixo de 1000 km -(\%), 0

Uso da caixa de plástico em distâncias acima de $1000 \mathrm{~km}-(\%)$

Uso da caixa de plástico em distâncias abaixo de $1000 \mathrm{~km}-(\%)$ 
APÊNDICE 3 - Dados específicos do entrevistado "2".

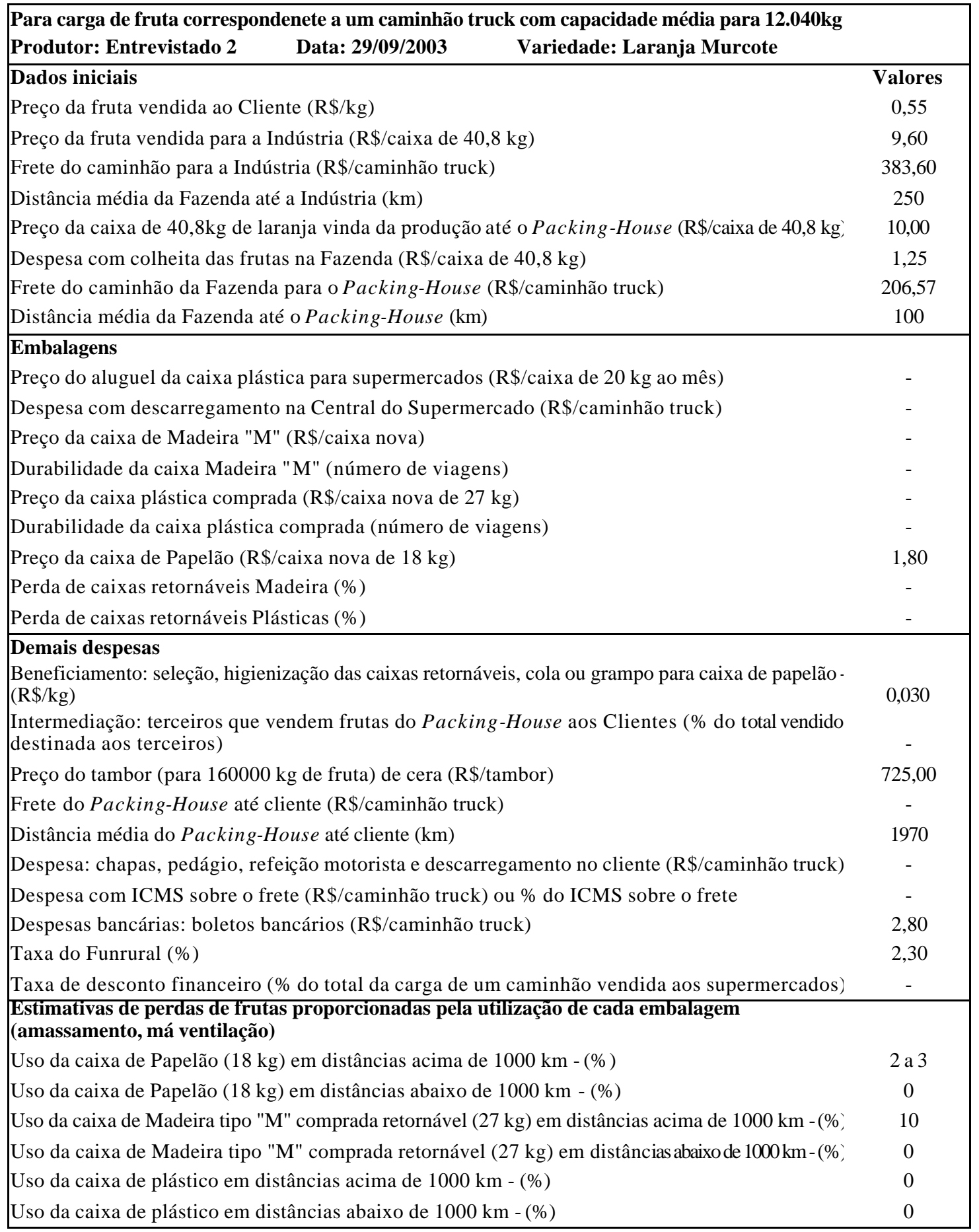


APÊNDICE 4 - Dados específicos do entrevistado "3".

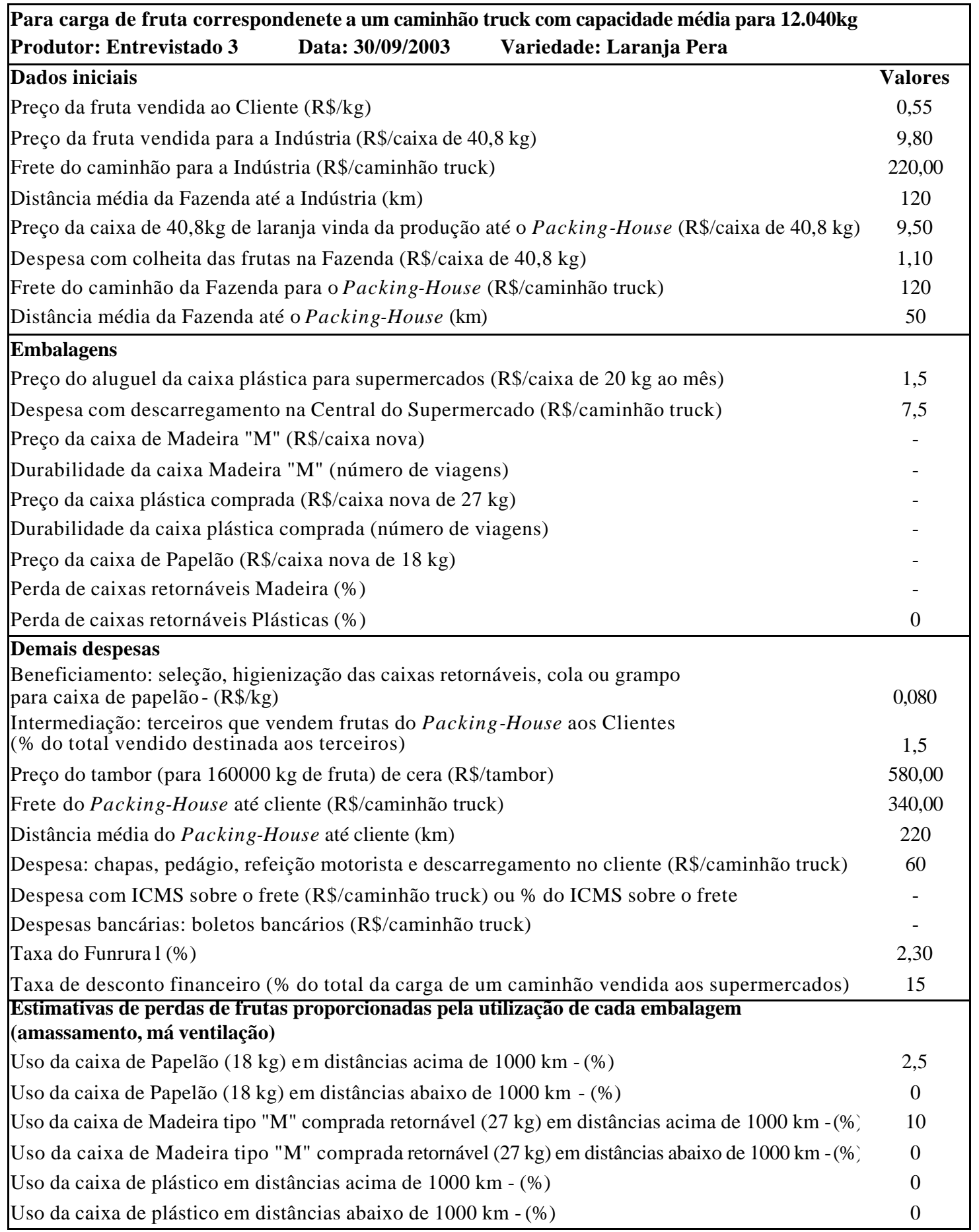

